
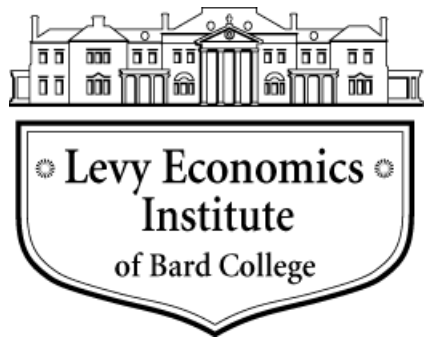

Working Paper No. 894

\title{
An Inquiry Concerning Long-term US Interest Rates Using Monthly Data
}

by

\author{
Tanweer Akram \\ Thrivent Financial
}

Huiqing Li

Central University of Finance and Economics

\begin{abstract}
August 2017
Tanweer Akram is director of global public policy and economics at Thrivent Financial. Huiqing Li is assistant professor in the School of National Fiscal Development at the Central University of Finance and Economics. The authors thank the participants of various seminars for their valuable suggestions. Disclaimer: The authors' institutional affiliations are provided solely for identification purposes. Views expressed are solely those of the authors and the standard disclaimer applies. The views are not necessarily those of Thrivent Financial, Thrivent Investment Management, or any affiliates. This is for information purposes only and should not be construed as an offer to buy or sell any investment product or service. Disclosure: Tanweer Akram's employer, Thrivent Financial, invests in a wide range of securities, including U.S. Treasury securities. Asset management services are provided by Thrivent Asset Management, LLC, a wholly owned subsidiary of Thrivent Financial for Lutherans.

Corresponding author: Tanweer Akram, Thrivent Financial, 625 Fourth Avenue South, Minneapolis, MN 55415-1665, USA; phone: 1-612-844-4639; e-mail: tanweer.akram@thrivent.com. Huiqing Li, Academic Hall South, Room 404, Central University of Finance and Economics, 39 South College Road, Haidian District, Beijing 100081, China; phone: 86-10-6228 8272; fax: 86-10-6228 8605; e-mail: huiqing_li@cufe.edu.cn
\end{abstract}

The Levy Economics Institute Working Paper Collection presents research in progress by Levy Institute scholars and conference participants. The purpose of the series is to disseminate ideas to and elicit comments from academics and professionals.

Levy Economics Institute of Bard College, founded in 1986, is a nonprofit, nonpartisan, independently funded research organization devoted to public service. Through scholarship and economic research it generates viable, effective public policy responses to important economic problems that profoundly affect the quality of life in the United States and abroad.

\author{
Levy Economics Institute \\ P.O. Box 5000 \\ Annandale-on-Hudson, NY 12504-5000 \\ http://www.levyinstitute.org
}

Copyright (C) Levy Economics Institute 2017 All rights reserved

ISSN 1547-366X 


\begin{abstract}
This paper undertakes an empirical inquiry concerning the determinants of long-term interest rates on US Treasury securities. It applies the bounds testing procedure to cointegration and error correction models within the autoregressive distributive lag (ARDL) framework, using monthly data and estimating a wide range of Keynesian models of long-term interest rates. While previous studies have mainly relied on quarterly data, the use of monthly data substantially expands the number of observations. This in turn enables the calibration of a wide range of models to test various hypotheses. The short-term interest rate is the key determinant of the longterm interest rate, while the rate of core inflation and the pace of economic activity also influence the long-term interest rate. A rise in the ratio of the federal fiscal balance (government net lending/borrowing as a share of nominal GDP) lowers yields on long-term US Treasury securities. The short- and long-run effects of short-term interest rates, the rate of inflation, the pace of economic activity, and the fiscal balance ratio on long-term interest rates on US Treasury securities are estimated. The findings reinforce Keynes's prescient insights on the determinants of government bond yields.
\end{abstract}

Keywords: Government Bond Yields; Long-term Interest Rates; Short-term Interest Rates; Monetary Policy; Central Bank; John Maynard Keynes

JEL Classifications: E43; E50; E58; E60; G10; G12 


\section{INTRODUCTION}

John Maynard Keynes (1930) argues that the central bank's actions determine government bond yields because the central bank is able to influence the short-term interest rates mainly through setting the benchmark policy rate(s). His view is that short-term interest rates are the main drivers of long-term interest rates. However, Keynes's argument that the central bank's actions are the key driver of long-term government bond yields is usually not emphasized in most of the existing literature on the determinants of government bond yields.

Most recent theoretical and empirical research on the determinants of government bonds yields and sovereign bond spreads emphasizes that government fiscal variables are the key drivers of interest rates, both on a long-run and a short-run basis. Various studies, such as Baldacci and Kumar (2010), Gruber and Kamin (2012), Lam and Tokuoka (2013), Paccagnini (2016), Poghoysan (2014), Reinhart and Rogoff (2009), and Tokuoka (2012) reiterate and reinforce this point. The existing literature focuses primarily on government fiscal variables, such as the ratios of government net lending/borrowing (fiscal balance) to nominal GDP, gross debt to nominal GDP, or net debt to nominal GDP, rather than short-term interest rates and the central bank's actions. The neglect of the Keynesian framework for understanding the dynamics of long-term interest rates is a critical lacuna in the literature.

Building on an emergent literature that uses a Keynesian framework, this paper offers an analysis of government bond yields for countries with sovereign currencies to explain the behavior of government bond yields, primarily in terms of short-term interest rates, the rates of inflation, and the pace of economic activity. It also critically assesses the effect of the fiscal balance ratio (government net lending/borrowing as a share of nominal GDP) on government bond yields. Some recent studies, such as Akram (2014), Akram and Das (2014, 2015, 2017a, and 2017b), and Akram and $\mathrm{Li}$ (2016 and 2017) apply the Keynesian framework in explaining government bond yields in several countries and regions, such as Japan, India, the United States, and the eurozone. 
This paper makes several contributions. First, it uses a straightforward and coherent Keynesian model of government bond yields, provides the empirical evidence to support this model, and calibrates the effects of government net lending/borrowing (fiscal balance) as a share of nominal GDP on government bond yields on both a short-term and long-term basis. Second, it extends Akram and Li's (2017) analysis of the determinants of US Treasury yields. Whereas Akram and Li's (2017) analysis relies on quarterly data, this paper uses monthly data, meaning there are more observations, which allows the calibration of a wider set of models to test various hypotheses. Higher frequency data enables one to discern empirical regularities and patterns both in the long and short run. Third, it applies the bounds testing procedure to cointegration and error correction models within the autoregressive distributive lag (ARDL) framework to econometrically calibrate the dynamic relations among fundamental macroeconomic variables that determine long-term interest rates on US Treasury securities.

The paper is organized as follows. Section 2 describes some important stylized facts about longterm interest rates in the United States (as reflected in Treasury yields) and other macroeconomic and financial variables that are regarded as the key drivers of long-term interest rates, such as short-term interest rates, the rates of core inflation, the pace of industrial production, and government fiscal variables in the US. Section 3 briefly describes Keynes's views on the main drivers of long-term interest rates in an uncertain world. It also provides a descriptive summary of Akram and Li's (2017) model, which guides the empirical implementation here for the inquiry concerning long-term interest rates in the US. Section 4 describes the data, its sources, and the adjustments undertaken here to obtain the relevant monthly series. It also undertakes unit root tests to determine the characteristics of the data. Section 5 presents the empirical approaches deployed in this study, reports the findings of several models that are estimated, and interprets the results obtained. Section 6 concludes with some reflections on the policy implications of the findings of this inquiry and identifies several areas for further research. The appendix contains additional tables that reinforce and extend the findings presented in the paper. 


\section{THE STYLIZED FACTS ABOUT LONG-TERM INTEREST RATES AND DRIVERS}

Figure 1 shows the evolution of long-term interest rates, as measured by the nominal yields of Treasury securities of selected tenors. Long-term interest rates generally rose in the 1970s as inflation had picked up due to the expansion related to the Vietnam War, the dismantling of the Bretton Woods monetary regime, and the oil shock of 1973. Several important features of the evolution of long-term interest rates are apparent from this figure. First, after an initial rise in long-term interest rates in the early 1970s, they remained steady until the second oil shock in 1979. Second, there was a spike in long-term interest rates in the early 1980s. Third, long-term interest rates have been on a declining trend from the early 1980s to the present. Fourth, longterm interest rates fell sharply after the Global Financial Crisis. Fifth, there was a moderate but noticeable rise in long-term interest rates in the US in early November 2016 after the stunning victory of Donald Trump in the country's presidential election. Sixth, long-term interest rates generally tend to fall during or after a recession (marked by shaded areas in the figures below).

Figure 1: The Evolution of Long-term Interest Rates in the United States

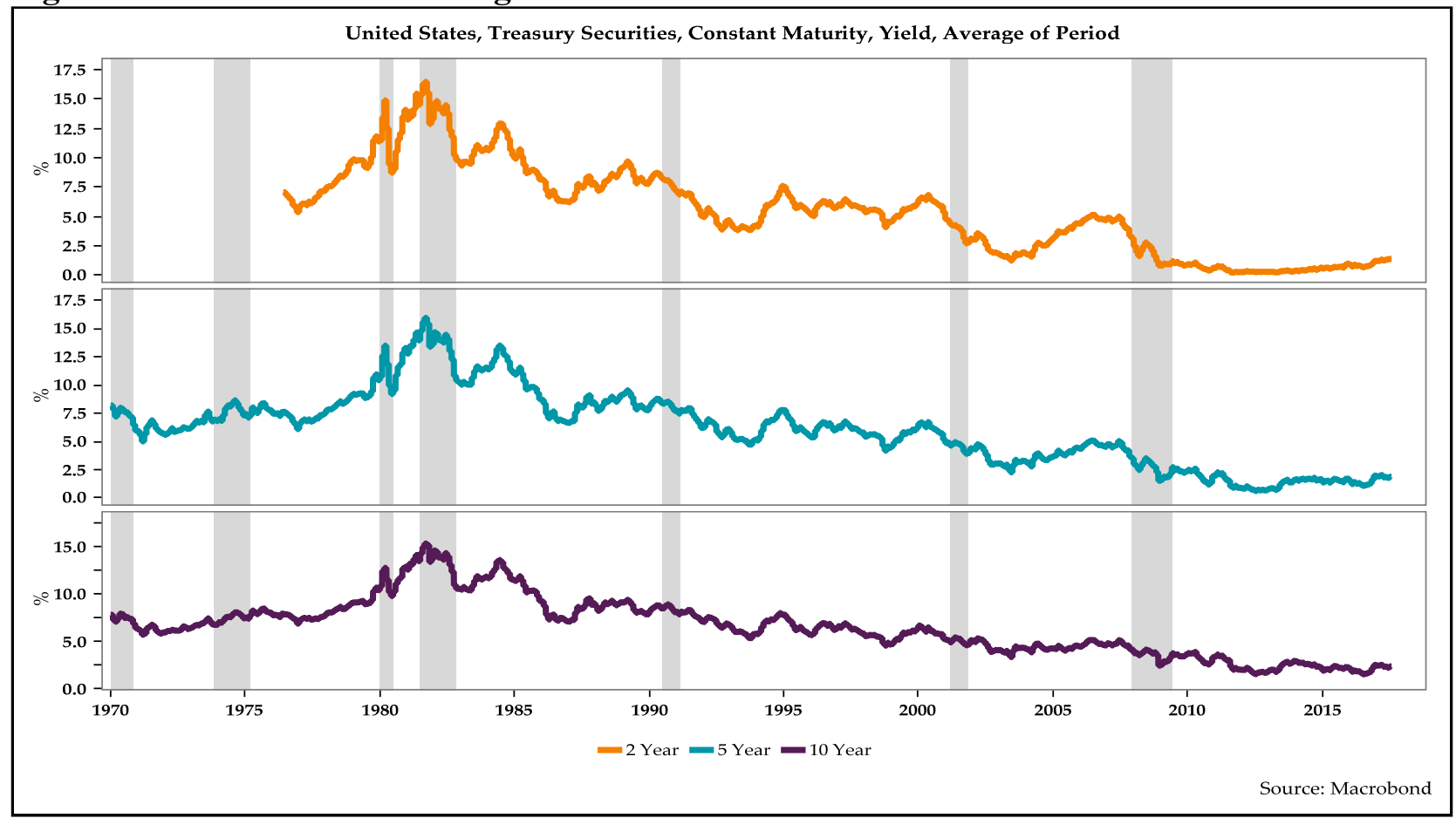


The evolution of short-term interest rates, as measured by the nominal yields of US Treasury bills of 3-month and 6-month tenors, displays a similar pattern to that of the long-term interest rates, as shown in figure 2. First, short-term interest rates on Treasury bills clearly tend to move in lockstep with the Federal Reserve's targeted policy rates. Second, short-term interest rates also spiked in the early 1980s, but have been on a declining trend since then until the present. Third, short-term interest rates decline during recessions as the Fed becomes accommodative and usually lowers its policy rates (such as the fed funds target rate and the discount rate) in response to increased slack in the US economy. Fourth, short-term interest rates tend to rise before the onset of a recession in response to the Fed's restrictive monetary policy and higher targeted policy rate(s).

\section{Figure 2: The Evolution of Short-term Interest Rates and Fed Funds Effective Rates}

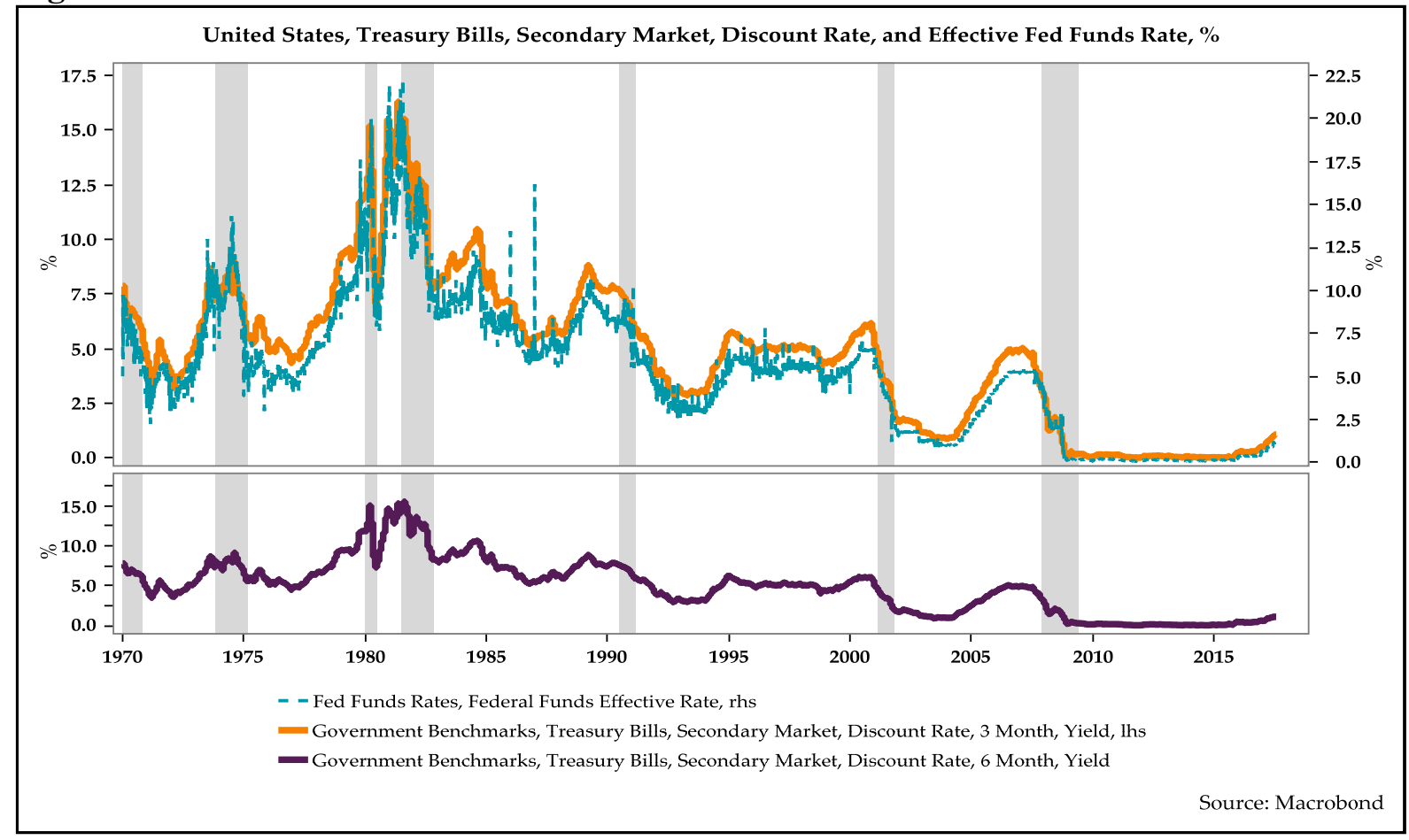

Inflationary pressure is an important driver of US Treasury yields. However, total inflation tends to be erratic due to the volatility of energy and food prices. Hence, investors rely on core inflation as a more reliable measure of underlying inflation pressures. In the US, the two key measures of core inflation are core personal consumption expenditure (PCE) inflation and core consumer price index (CPI) inflation. These measures of core inflation are obtained by excluding 
energy and food prices from the indices of total PCE and total CPI inflation. The evolution of these two indices, as shown in figure 3 , reveals certain patterns. First, core inflation rose sharply immediately after the first oil shock in 1973. Second, core inflation spiked after the second oil shock in 1979. Third, inflationary pressures began to subside only after the monetary tightening induced by Paul Volcker and the double-dip recessions of the early 1980s. Fourth, core inflationary pressures have moderated noticeably since the early 1990s.

Figure 3: The Evolution of Rates of Core Inflation in the US

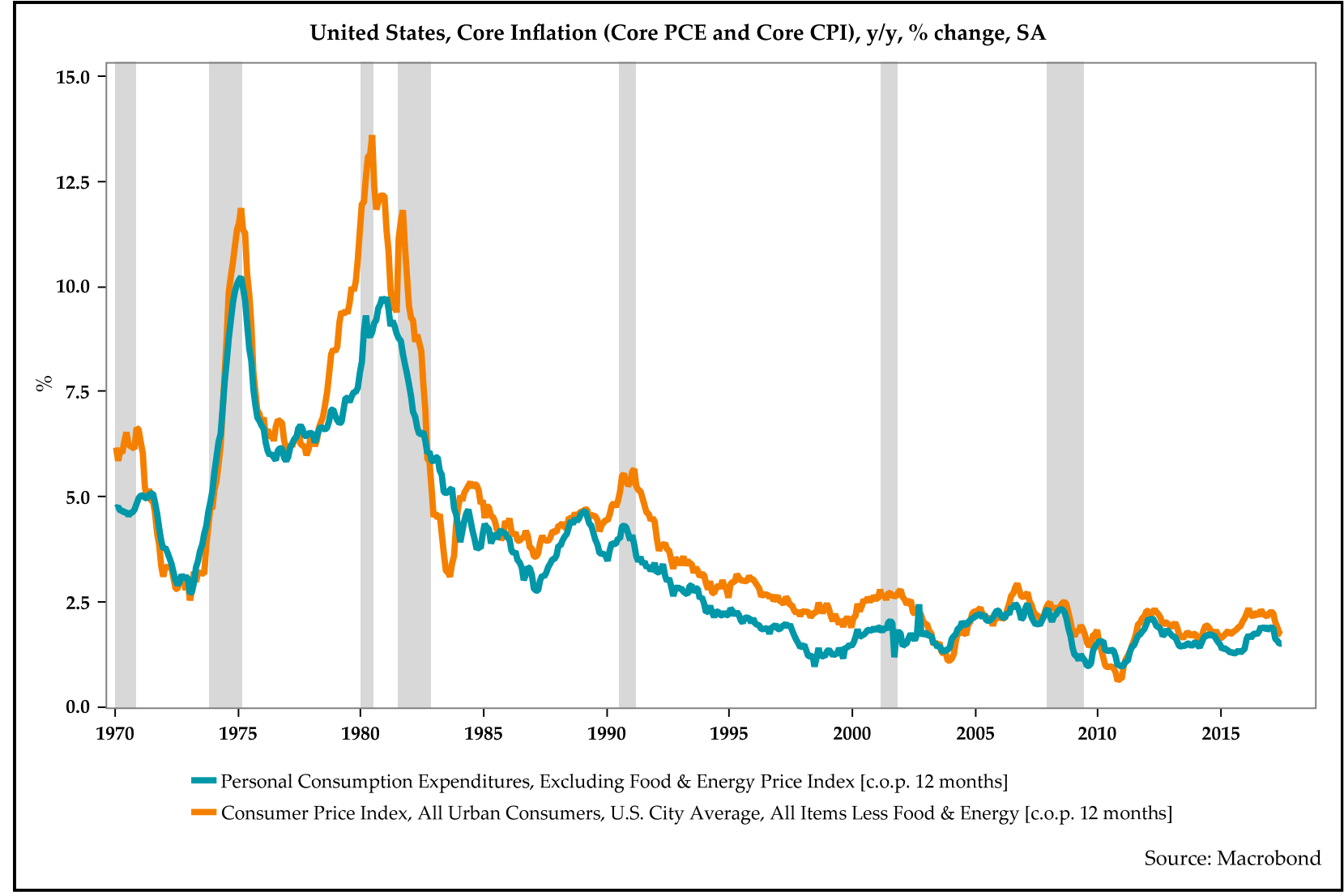

Industrial production in the US economy generally tends to grow, except sometimes before recessions and during recessions, as shown in figure 4. Marked slowdowns in the growth of industrial production and/or the outright decline of industrial production are very useful indicators of the likelihood of a recession. 


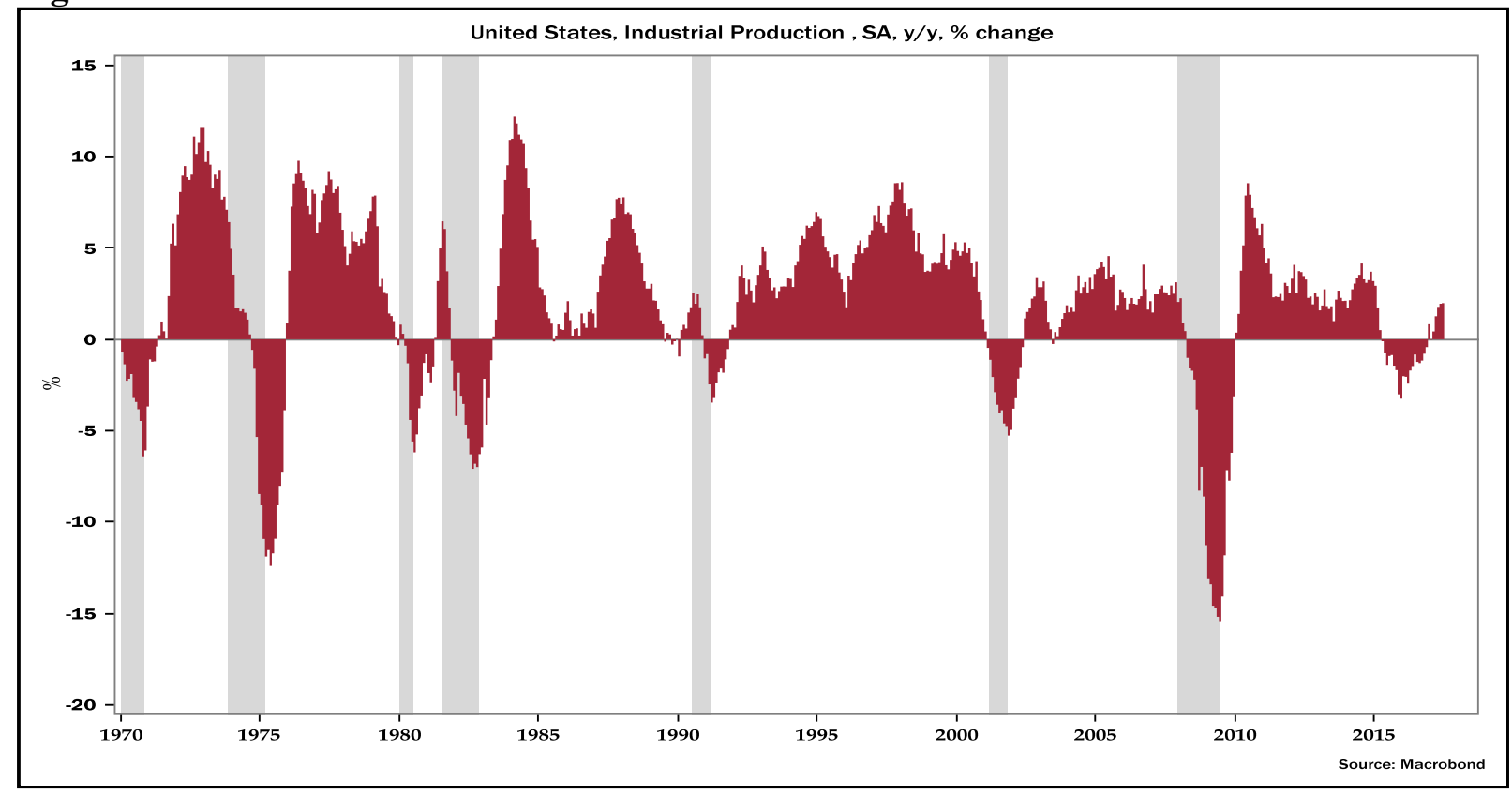

The growth of industrial production captures the vicissitudes of business cycle trends in the US quite well. This can be shown by examining the correlation between industrial production and real gross domestic production (RGDP). When the growth of both indicators is measured as a year-over-year percentage change, as shown in the scatter plot provided in figure $5 \mathrm{~A}$, there is a tight correlation. When the growth of both of these indicators is measured as a quarter-overquarter percentage change, as shown in the scatter plot provided in figure $5 \mathrm{~B}$, there is a decent positive correlation. However, the correlation is a bit weaker when the growth rate is measured on a quarter-over-quarter basis rather than a year-over-year basis. 
Figure 5A: The Year-over-Year Growth in Industrial Production Is Tightly Correlated with Overall Economic Activity as Measured by the Year-over-Year Growth in Real GDP

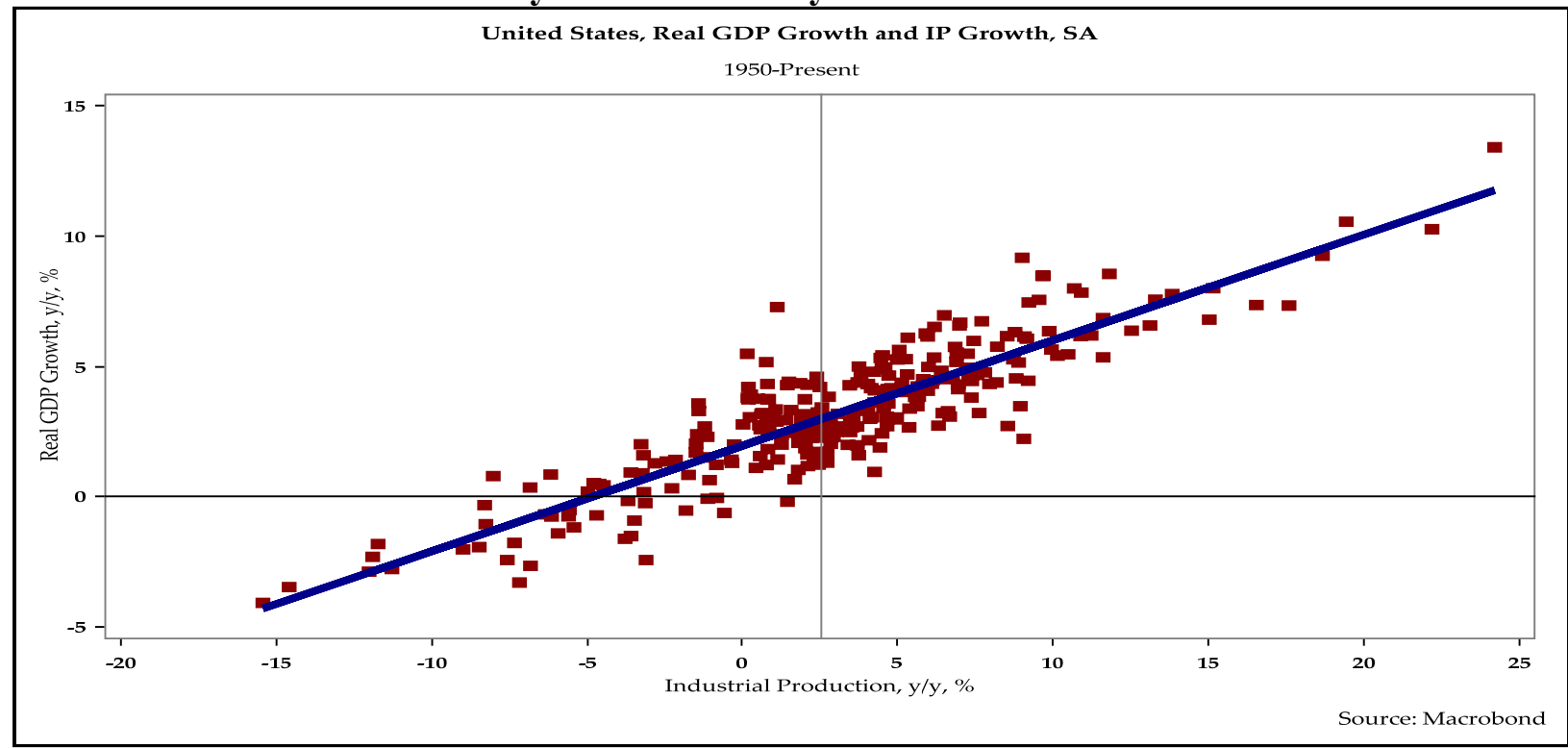

Figure 5B: The Quarter-over-Quarter Growth in Industrial Production Is Also Positively Correlated with Overall Economic Activity as Measured by the Quarter-over-Quarter Growth in Real GDP

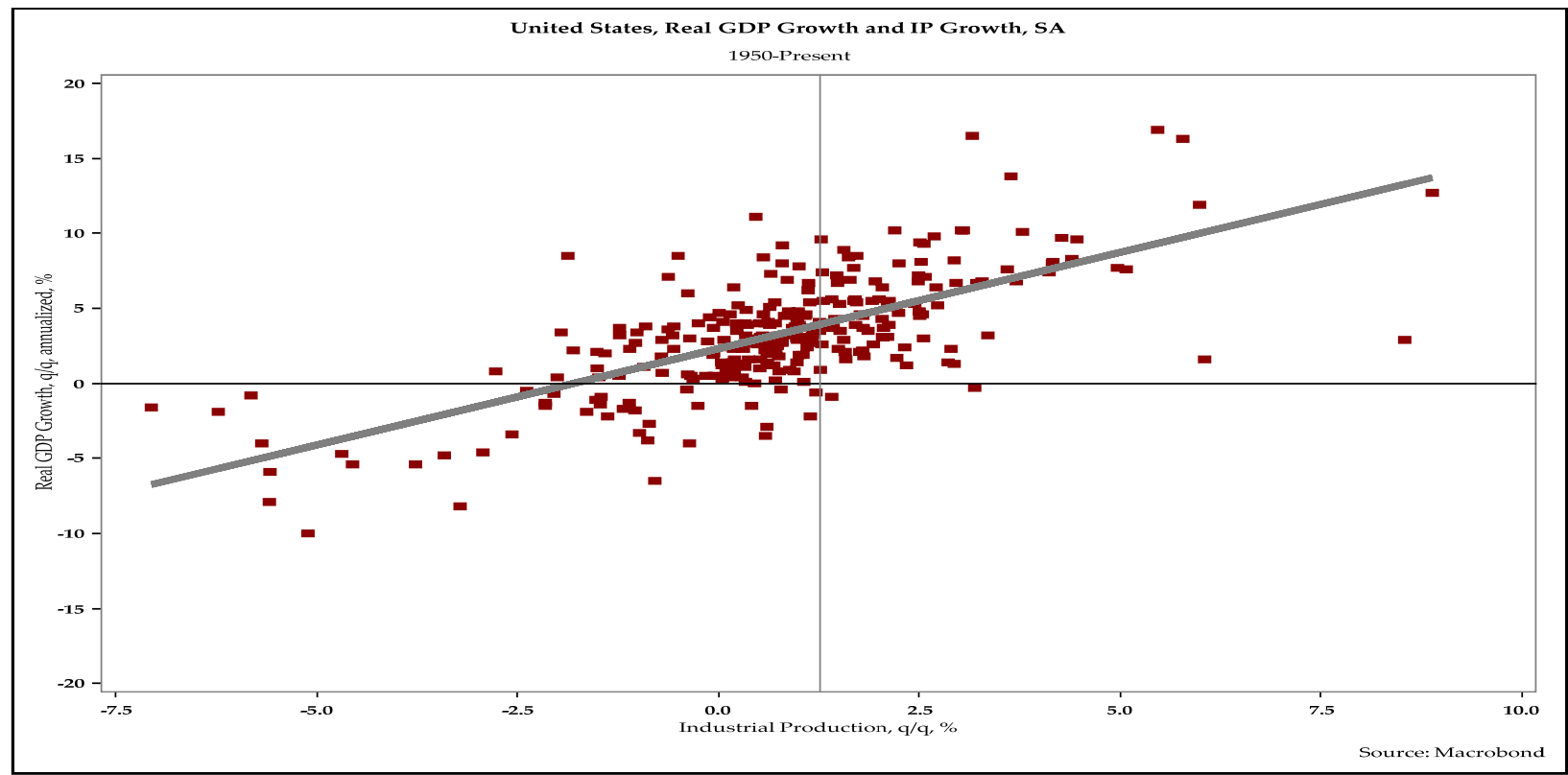


Figure 6 shows the evolution of the ratio of the federal fiscal balance. When the federal fiscal balance is positive (negative) it indicates a fiscal surplus (deficit). It brings to light several patterns. First, most often in the US the federal government operates with a fiscal deficit, which means that the federal government is a net borrower from the nongovernment sectors in most years. Second, in response to a recession, the federal fiscal deficit as a share of nominal GDP typically widens. This is partly due to automatic stabilizers, such as progressivity in tax rates and unemployment compensation benefits, as well as fiscal stimulus to counter the slowdown in economic activity. Moreover, in a recession nominal GDP shirks or stagnates. As a result of these factors, the fiscal balance ratio declines. Third, as the economy recovers, the fiscal balance ratio tends to rise. Fourth, a recession often occurs as fiscal deficits begin to shrink or as fiscal balances begin to turn into fiscal surpluses.

It is crucial to bear in mind that the fiscal balance is not a control variable for economic policymakers but rather it is an outcome of economic conditions, even though tax policy, tax rates, discretionary expenditure decisions, fiscal policy, and even mandatory fiscal transfers are decision variables that are subject to shifts in economic conditions, political regimes, policy preferences, and ideology.

Figure 6: The Evolution of the Federal Fiscal Balance Ratio

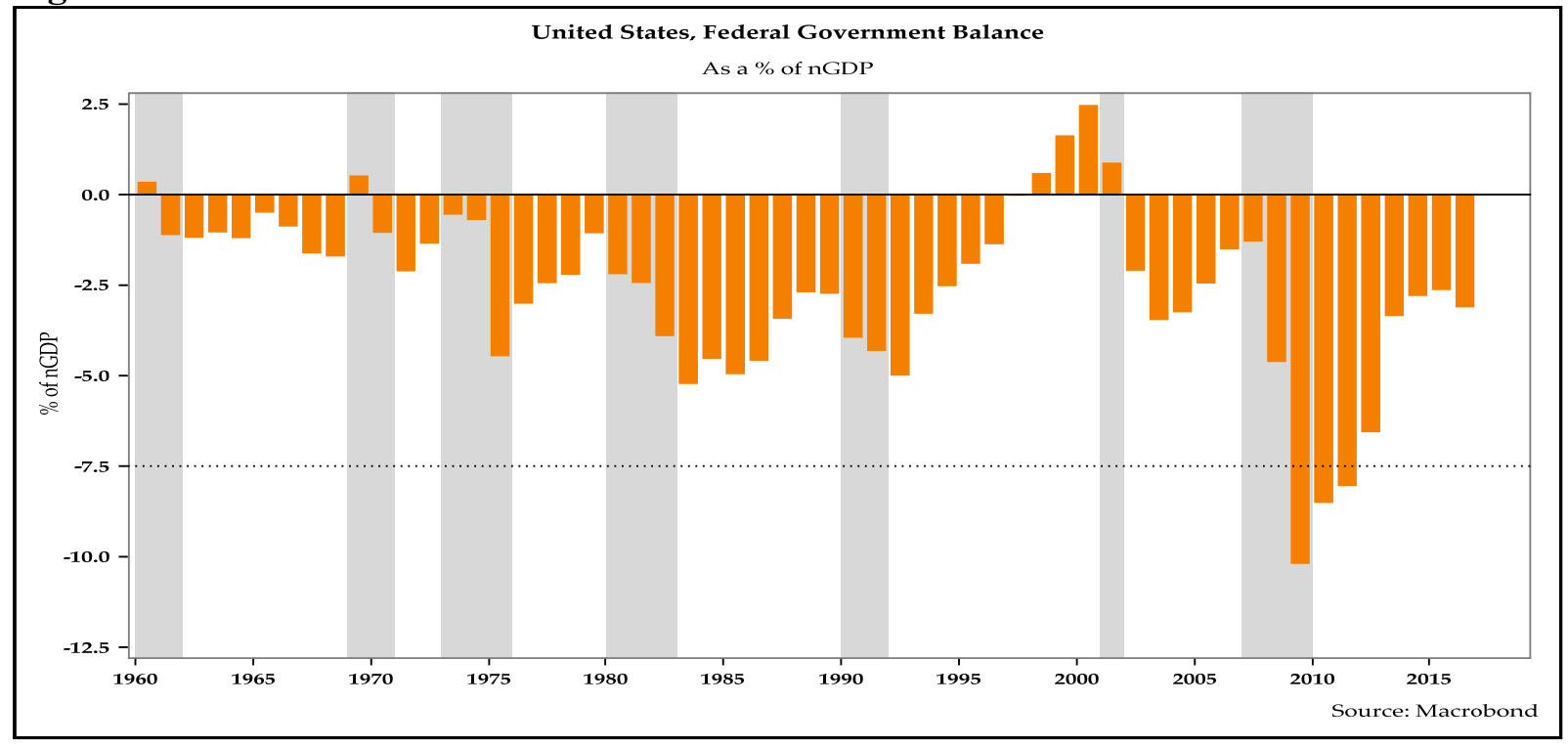


Figure 7 displays the evolution of the federal government debt as share of nominal GDP. It also gives a decomposition of the gross debt of the federal government. It is quite useful to decompose federal debt by its ownership, as argued in Fullwiler (2016). A large part of the federal debt is held in federal government accounts, such as Social Security and Medicare; the rest is held by the public. The federal debt held by the public includes: the US domestic private sector, consisting of financial institutions, corporations, and households; the Federal Reserve; and the rest of the world. The relevant metrics for gauging government indebtedness are: the ratio of federal government debt held by the public, including the Federal Reserve, as a share of nominal GDP; and the ratio of the federal government debt held by the public, excluding the Federal Reserve, as a share of nominal GDP. Since the Federal Reserve is a public entity, excluding the Federal Reserve's holding of Treasury securities, in essence, shows the federal government debt held by the private sector (which consists of the domestic private sector and the rest of the world) as a share of nominal GDP.

\section{Figure 7: The Evolution of Federal Government Debt Ratio and its Decomposition}

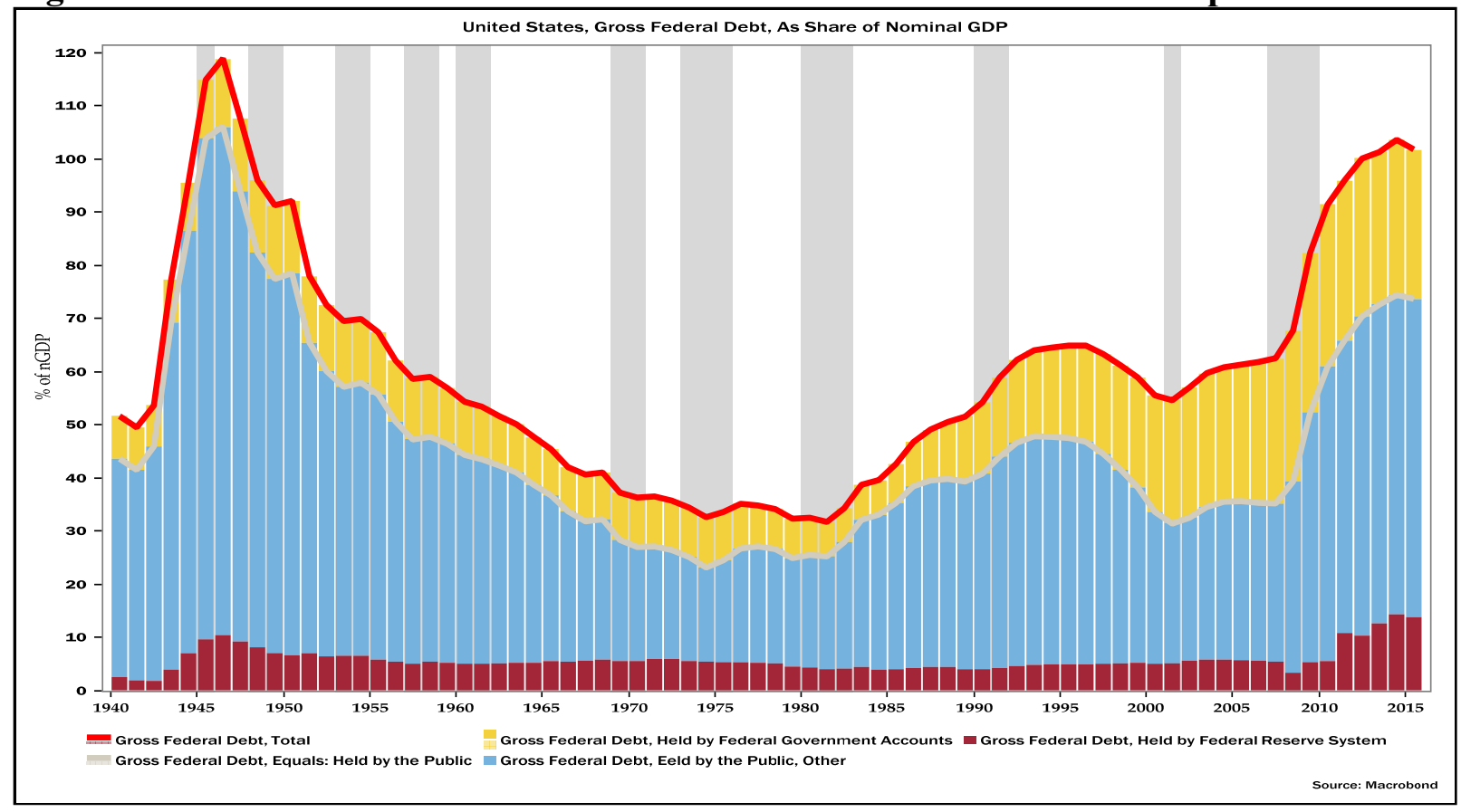


The evolution of the federal-debt-to-nominal-GDP ratio displays several things. First, the debt ratio rose markedly during the World War II era and peaked in the late 1940s. Second, it declined sharply from the early 1950s to the early 1980s. Third, the debt ratio rose again in the late 1980s to mid-1990s. Fourth, it remained stable from the mid-1990s until the Global Financial Crisis. Fifth, the debt ratio rose sharply with the Global Financial Crisis in the late 2000s. Sixth, the share of gross federal debt held by federal government accounts has risen notably since the late 1990s. Seventh, the share of federal debt held by the Federal Reserve rose during the World War II years, declined subsequently, and remained fairly steady until the Global Financial Crisis, when it rose sharply.

The figures below reveal some empirical patterns in the relationship between long-term interest rates and short-term interest rates, using monthly data on short-term Treasury bills and long-term Treasury securities of various tensors. Figure 8 is a scatterplot of the yields of Treasury securities of a 2-year tenor and 3-month Treasury bills. Figure 9 is a scatterplot of the year-over-year percentage point changes in the yields of Treasury securities of a 2-year tenor and 3-month Treasury bills. Figure 10 is a scatterplot of the yields of US Treasury securities of a 5-year tenor and 3-month Treasury bills. Figure 11 is a scatterplot of the year-over-year percentage point changes in the yields of Treasury securities of a 5-year tenor and 3-month Treasury bills. Figure 12 is a scatterplot of the yields of Treasury securities of a 7-year tenor and 3-month Treasury bills. Figure 13 is a scatterplot of the year-over-year percentage point change in the yields of Treasury securities of a 7-year tenor and 3-month Treasury bills. Figure 14 is a scatterplot of the yields of Treasury securities of a 10-year tenor and 3-month Treasury bills. Figure 15 is a scatterplot of the year-over-year percentage point changes in the yields of Treasury securities of a 10-year tenor and 3-month Treasury bills. Figure 16 is a scatterplot of the yields of Treasury securities of a 30-year tenor and 3-month Treasury bills. Figure 17 is a scatterplot of the yearover-year percentage point changes in the yields of Treasury securities of a 30-year tenor and 3month Treasury bills.

These scatterplots display several key empirical regularities. First, there is a strong positive correlation between the long-term interest rates on Treasury securities and the short-term interest rates on Treasury bills. Second, there is also a positive correlation between the year-over-year 
percentage point changes in the long-term interest rates on Treasury securities and the percentage point changes over the same period in the short-term interest rates on Treasury bills. Third, the correlation in the level of yields between Treasury securities and Treasury bills is much stronger than the correlation in the year-over-year percentage point changes in yields between the same Treasury securities and the same Treasury bills. Fourth, the tight correlation between the longterm interest rates on Treasury securities and the short-term interest rate on Treasury bills gradually declines for Treasury securities with longer tenors. Fifth, the positive correlation between the year-over-year percentage point changes in the long-term interest rates on Treasury securities and the percentage point changes over the same period in the short-term interest rates on Treasury bills also declines for Treasury securities with longer tenors. 
Figure 8: Scatterplot of the Yields of 2-year Treasury Securities and 3-month Treasury Bills

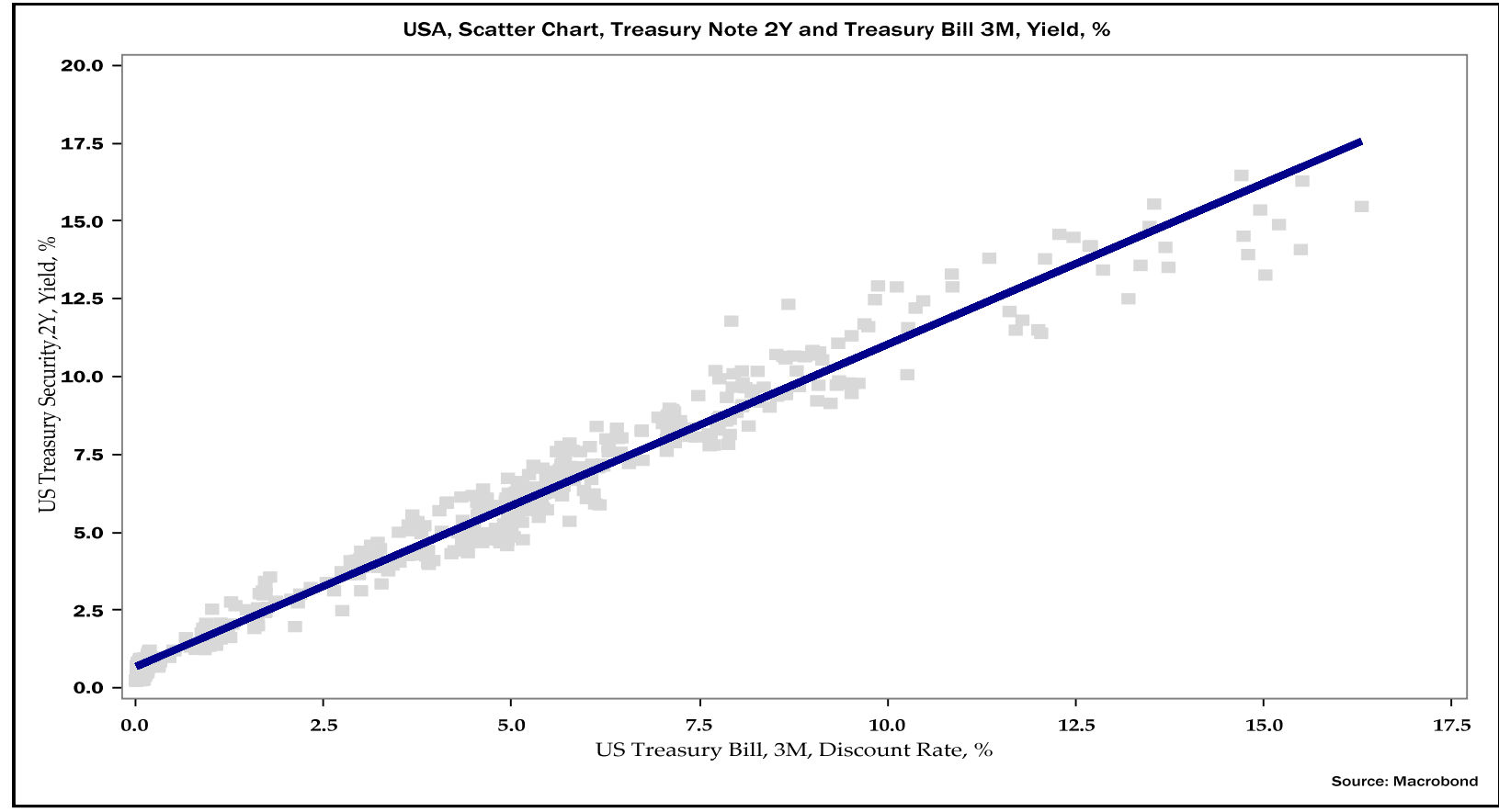

Figure 9: Scatterplot of the Year-over-Year Percentage Point Changes in Yields of 2-year Treasury Securities and 3-month Treasury Bills

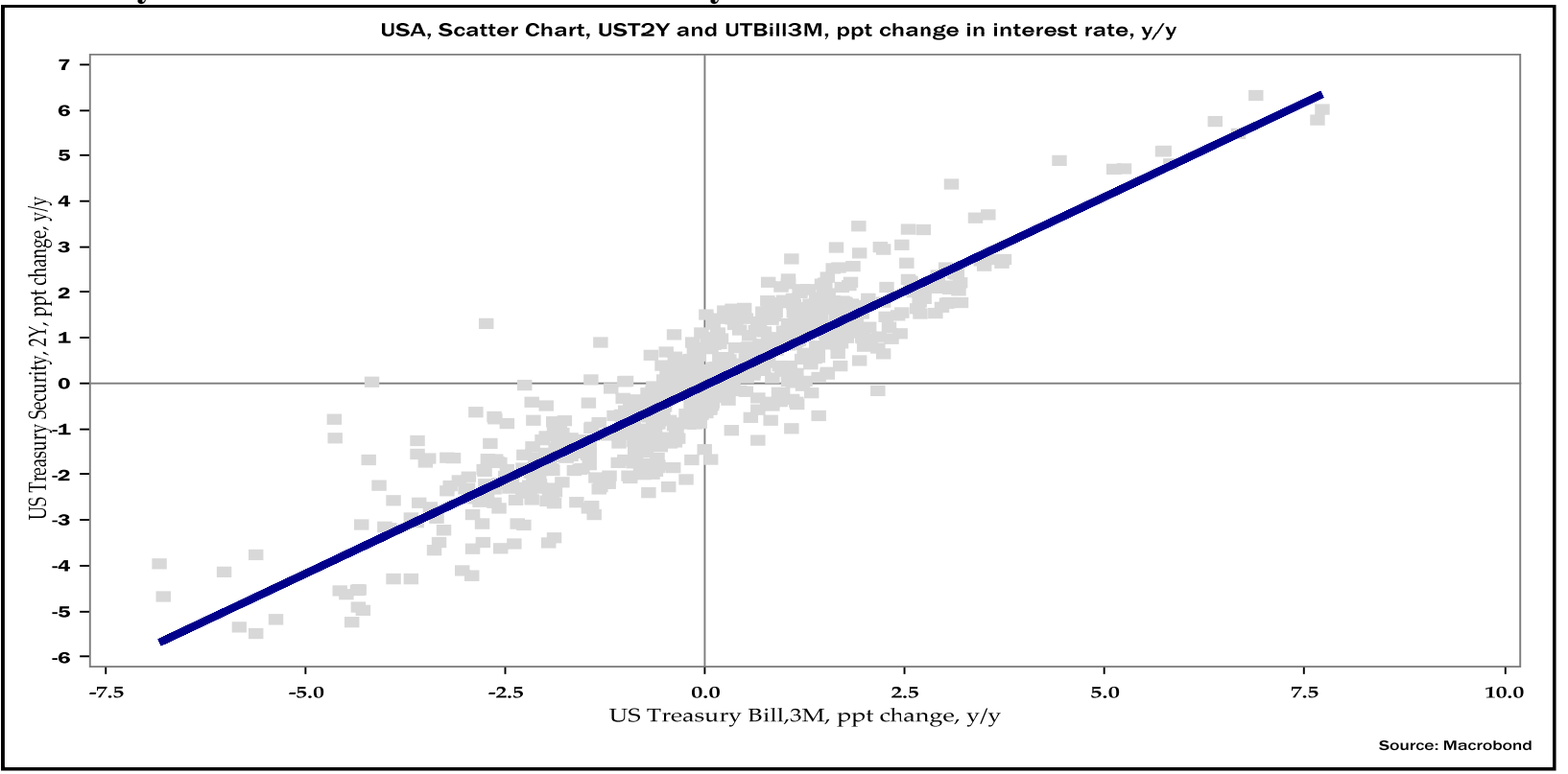


Figure 10: Scatterplot of the Yields of 5-year Treasury Securities and 3-month Treasury Bills

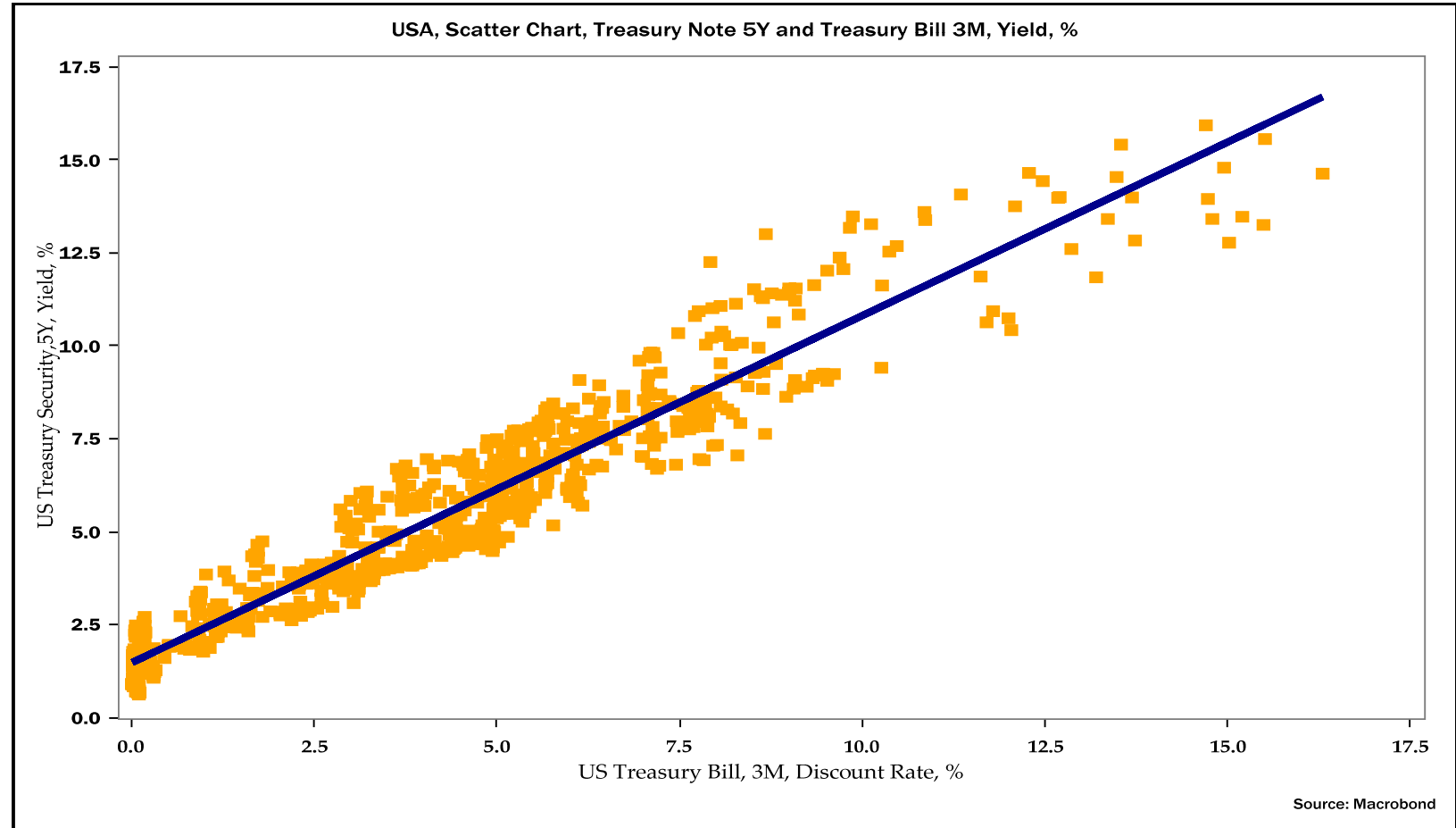

Figure 11: Scatterplot of the Year-over-Year Percentage Point Changes in Yields of 5-year Treasury Securities and 3-month Treasury Bills

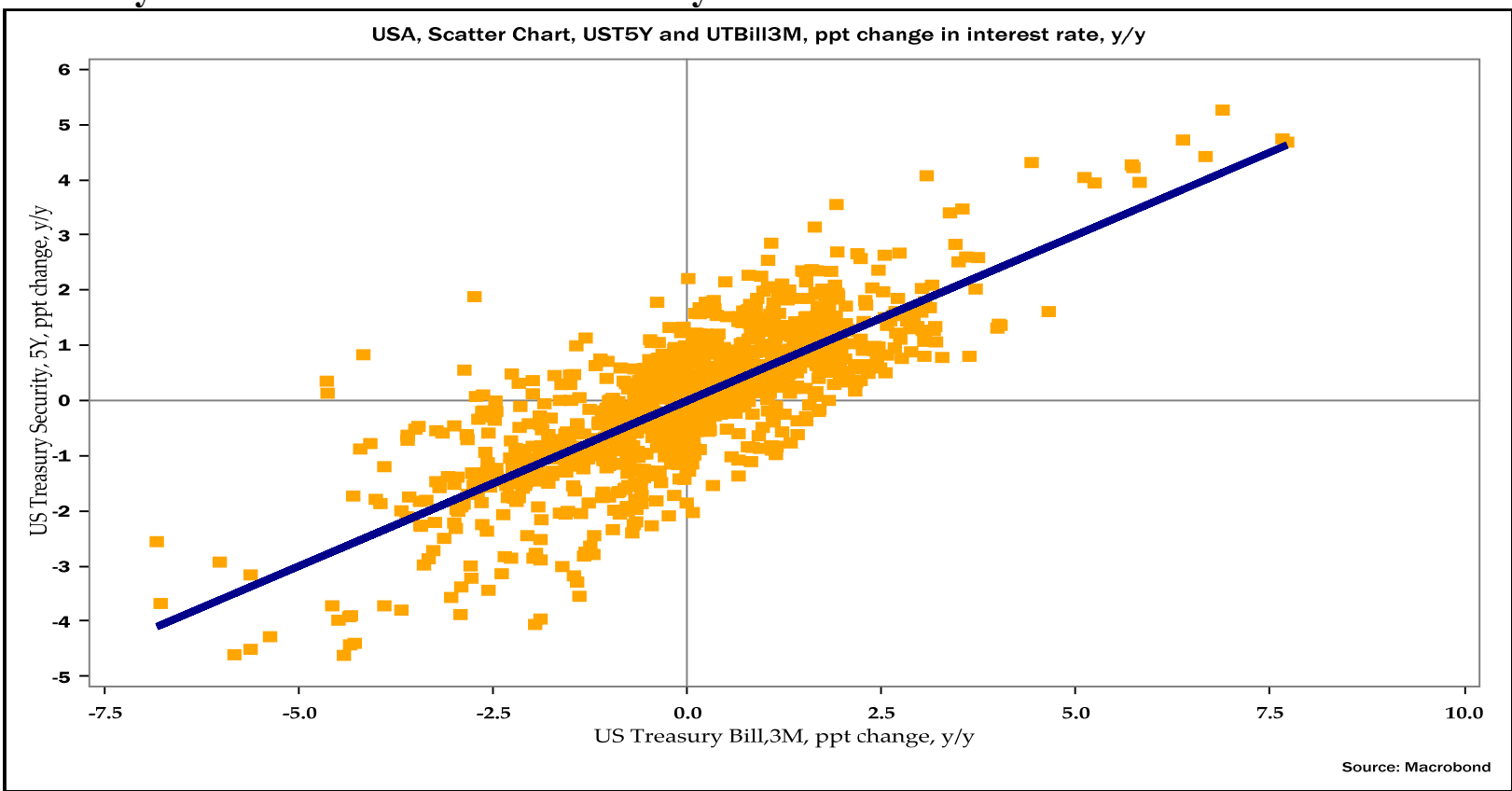


Figure 12: Scatterplot of the Yields of 7-year Treasury Securities and 3-month Treasury Bills

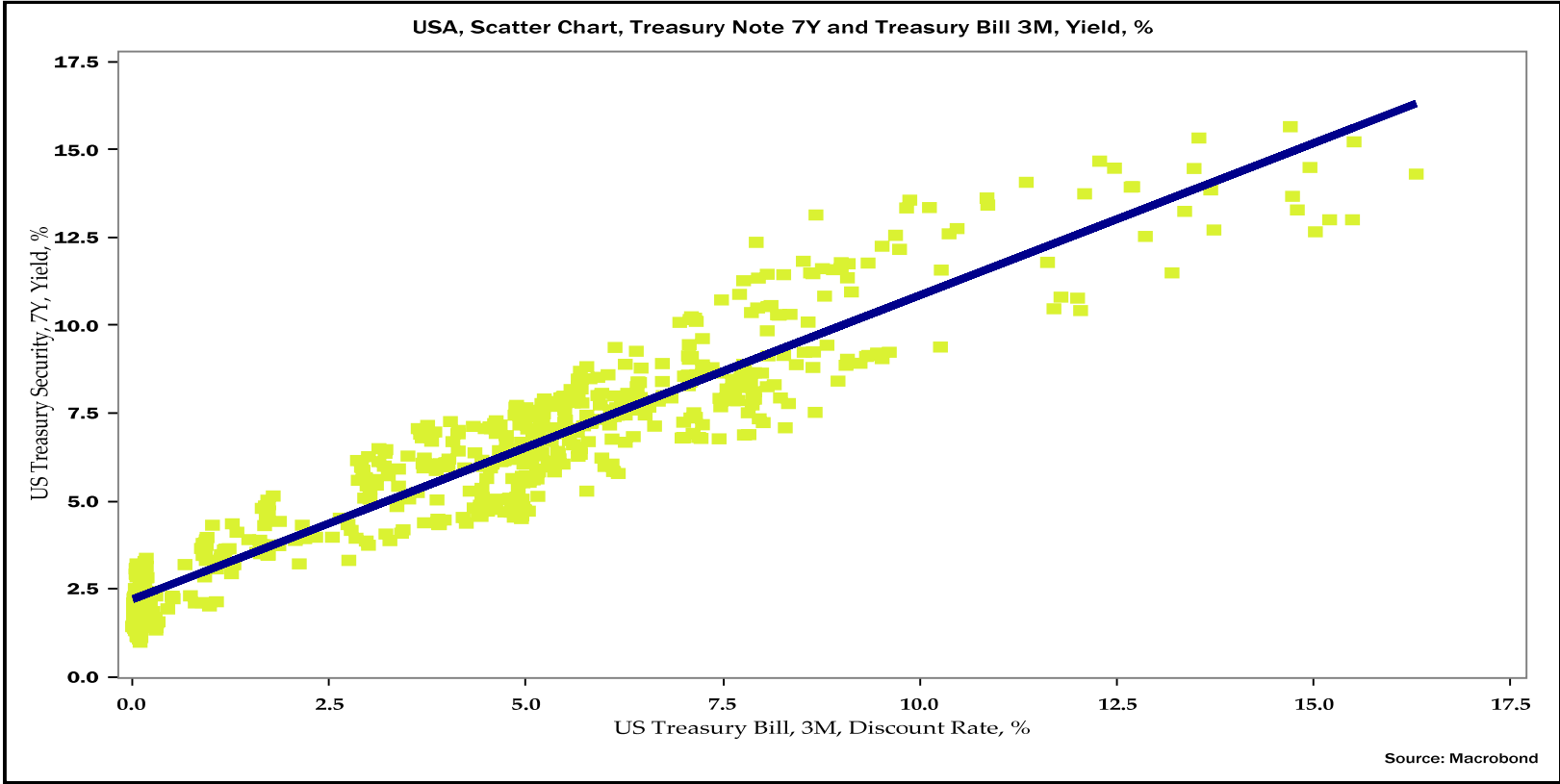

Figure 13: Scatterplot of the Year-over-Year Percentage Point Changes in Yields of 7-year Treasury Securities and 3-month Treasury Bills

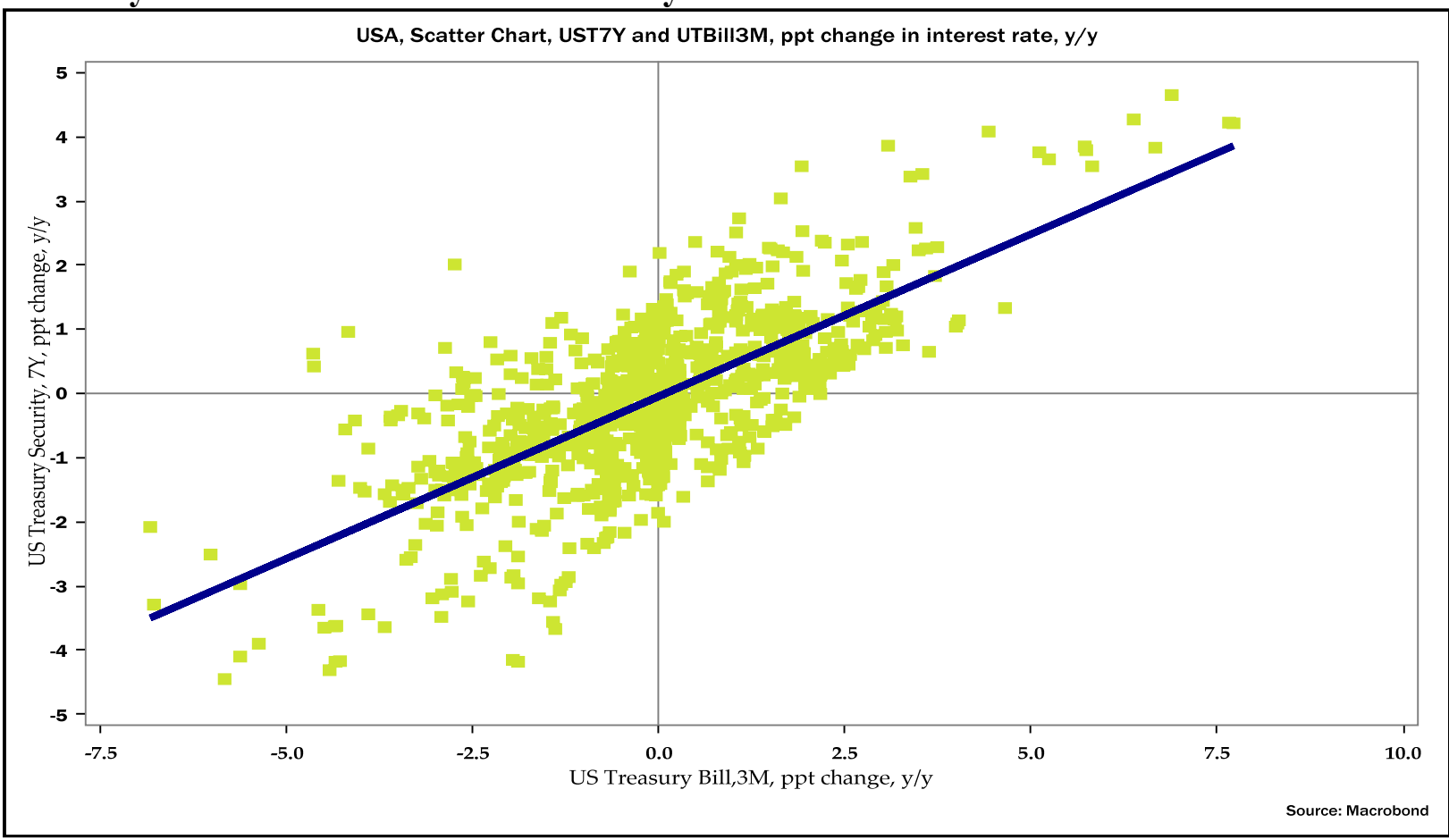


Figure 14: Scatterplot of the Yields of 10-year Treasury Securities and 3-month Treasury Bills

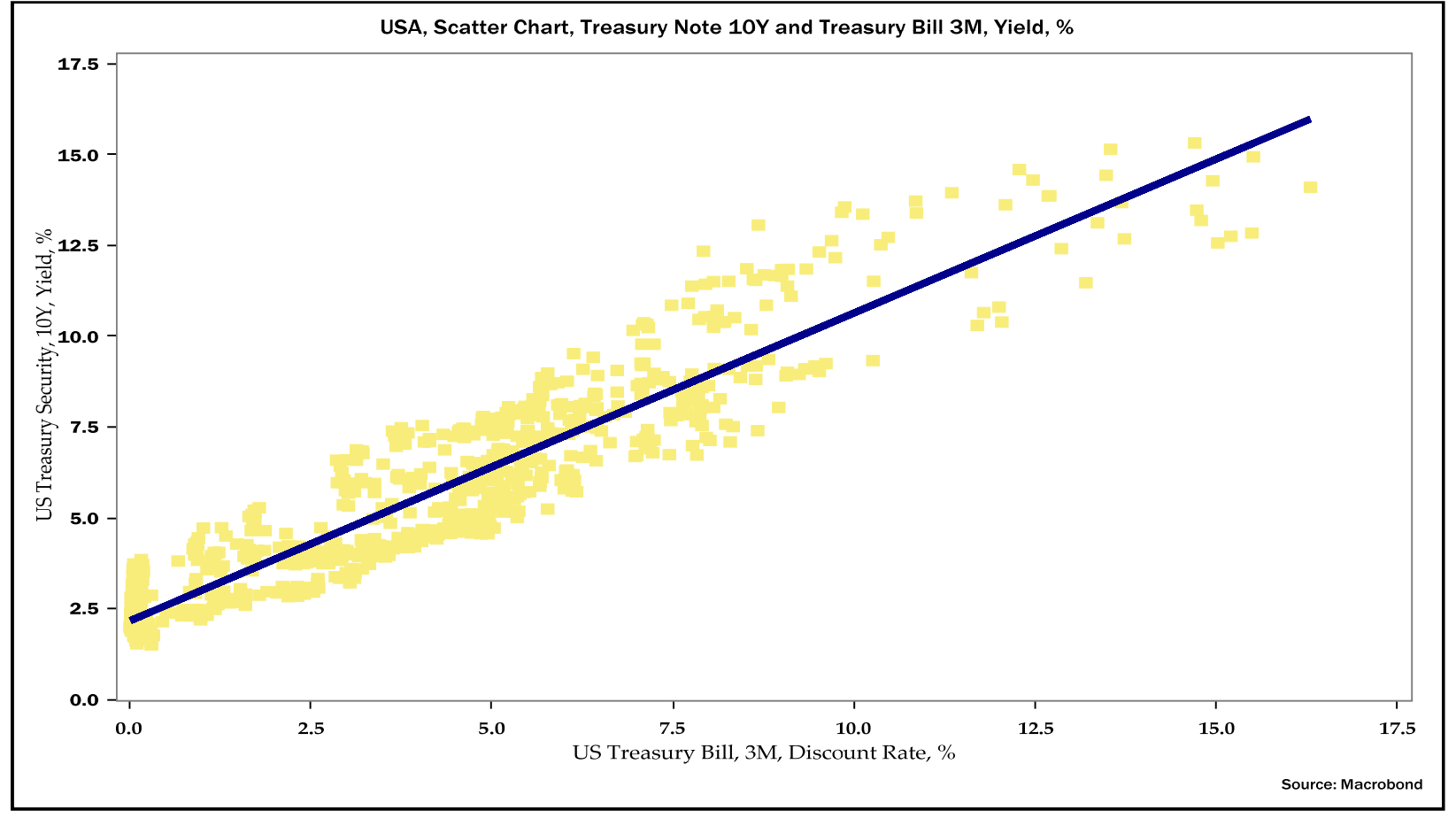

Figure 15: Scatterplot of the Year-over-Year Percentage Point Changes in Yields of 10year Treasury Securities and 3-month Treasury Bills

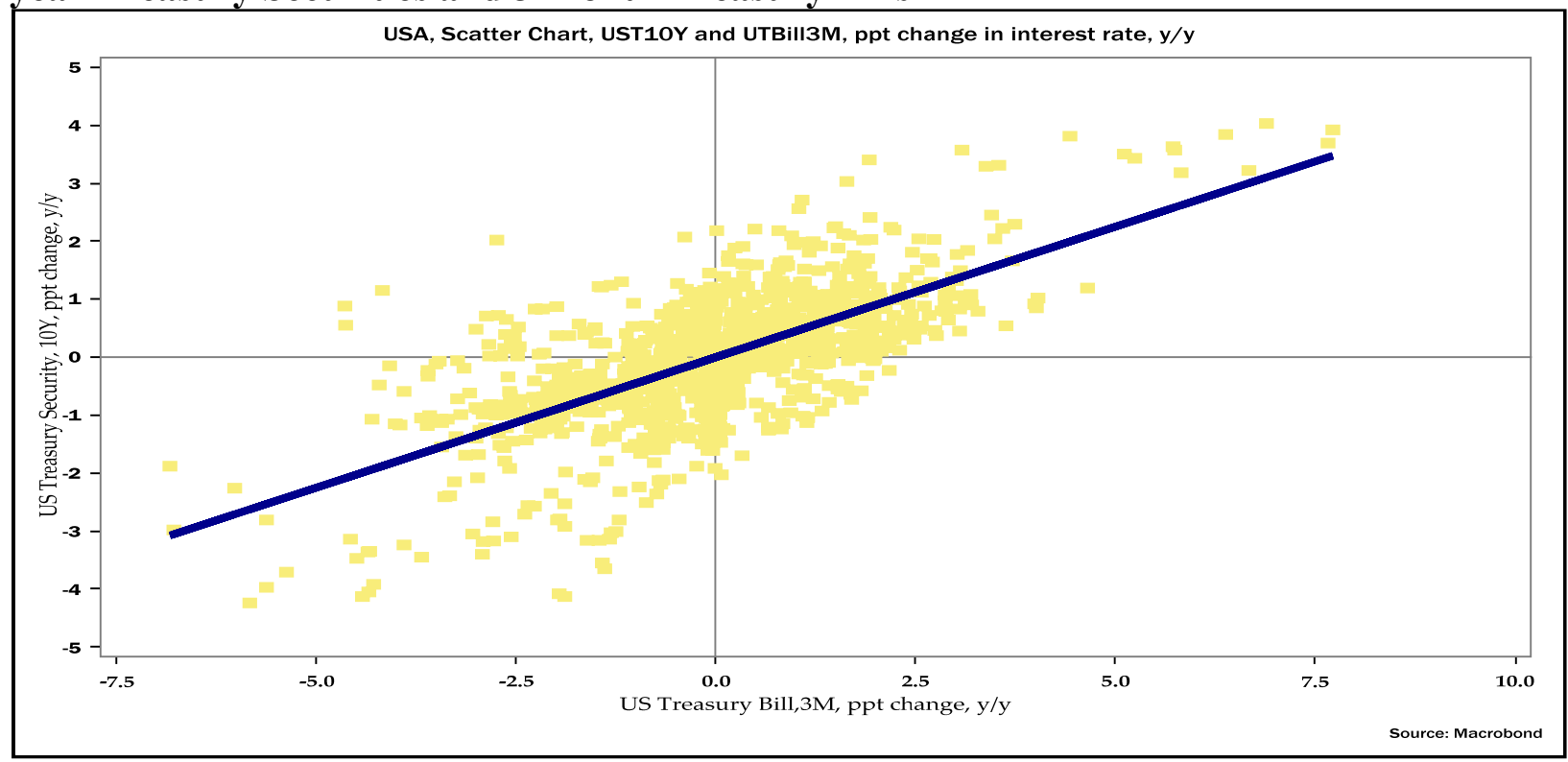


Figure 16: Scatterplot of the Yields of 30-year Treasury Securities and 3-month Treasury Bills

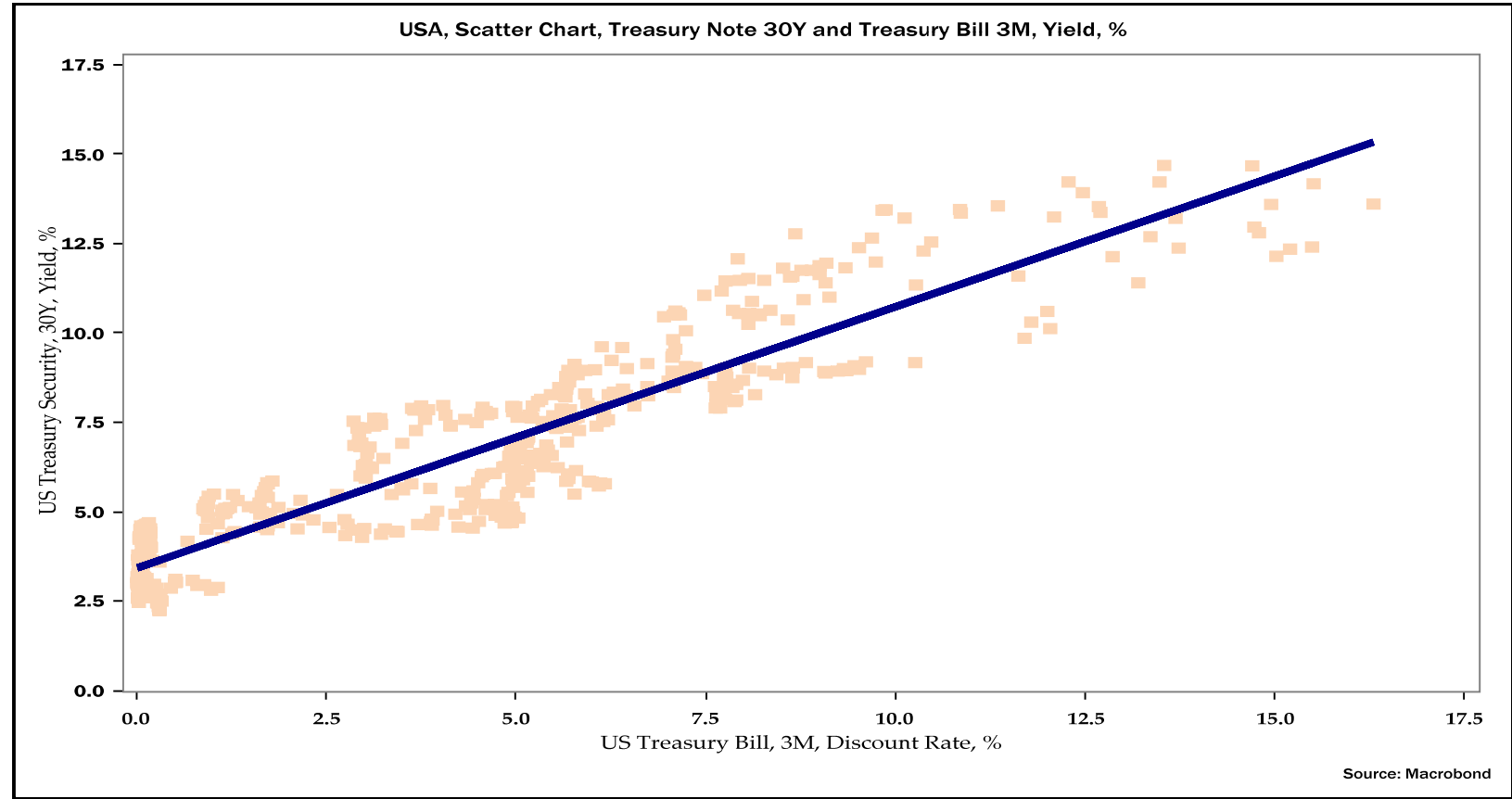

Figure 17: Scatterplot of the Year-over-Year Percentage Point Changes in Yields of 30year Treasury Securities and 3-month Treasury Bills

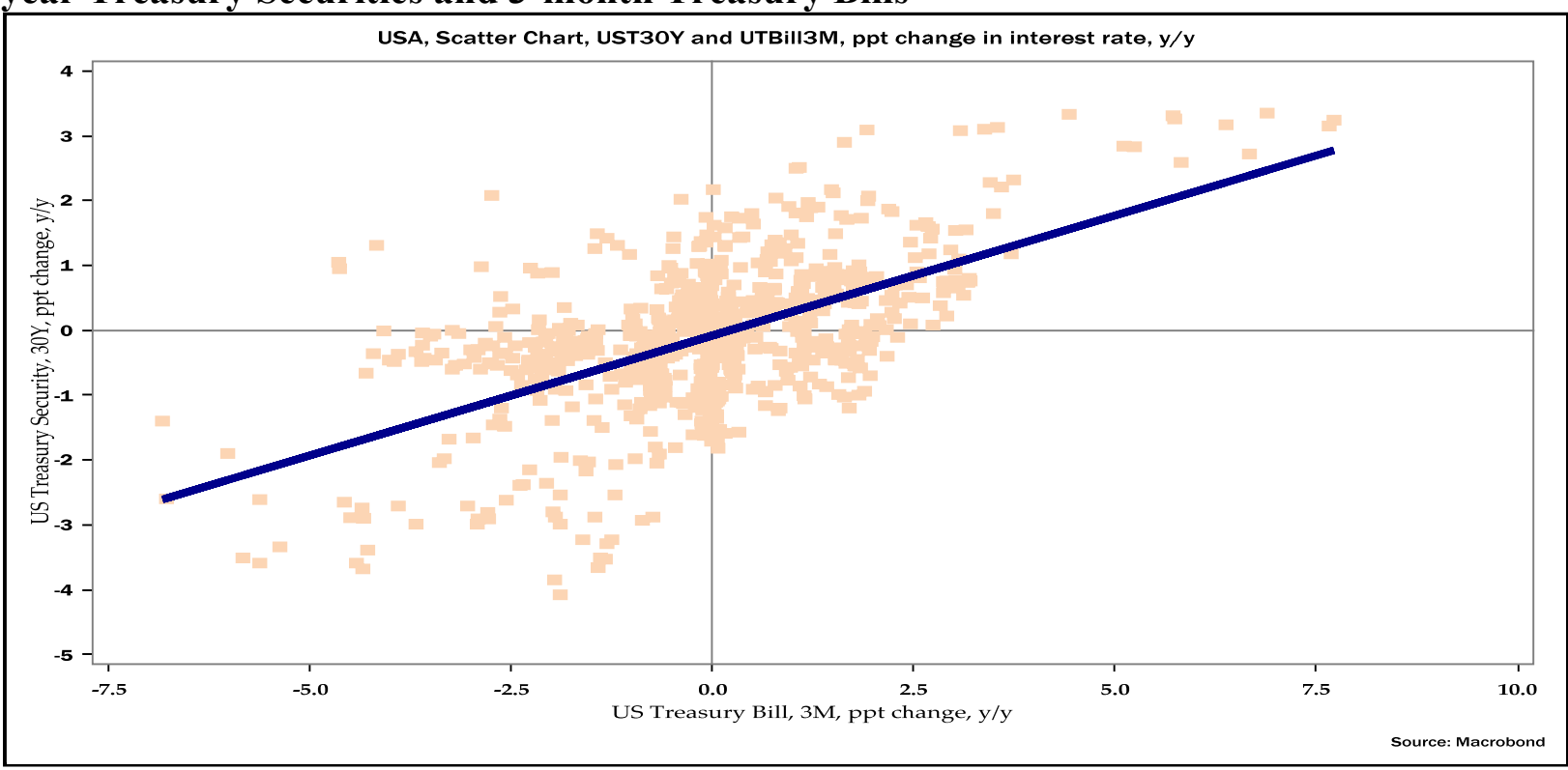


Treasury securities' nominal yields tend to move in tandem with various measures of the rates of core PCE and CPI inflation, as shown in figure 18. Investors in financial securities, particularly bonds, expect to be compensated for taking inflation risks, as measured by the rates of core inflation. The nominal interest rate is the sum of the real interest rates and some measure of inflationary expectations, and is typically higher than the rates of core inflation or inflationary expectations, but not always. Figure 19 displays the scatterplot of the yields of Treasury securities of a 10-year tenor and the rates of core inflation, as measured by the year-over-year percentage change in core inflation.

Figure 18: The Evolution of Long-term Interest Rates on Treasury Securities and the Rates of Core Inflation

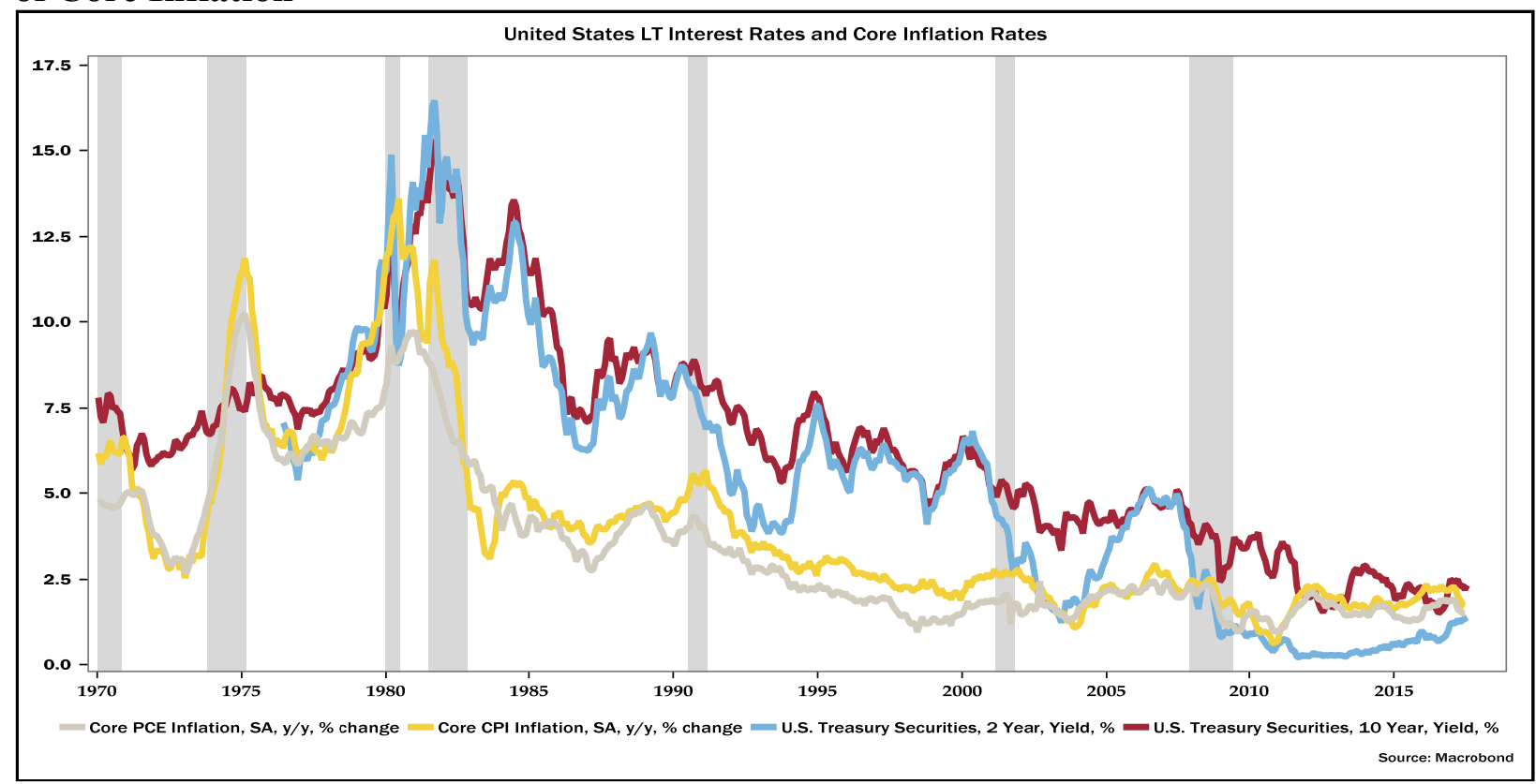


Figure 19: Scatterplot of the Yields of 10-year Treasury Securities and the Rate of Core PCE Inflation

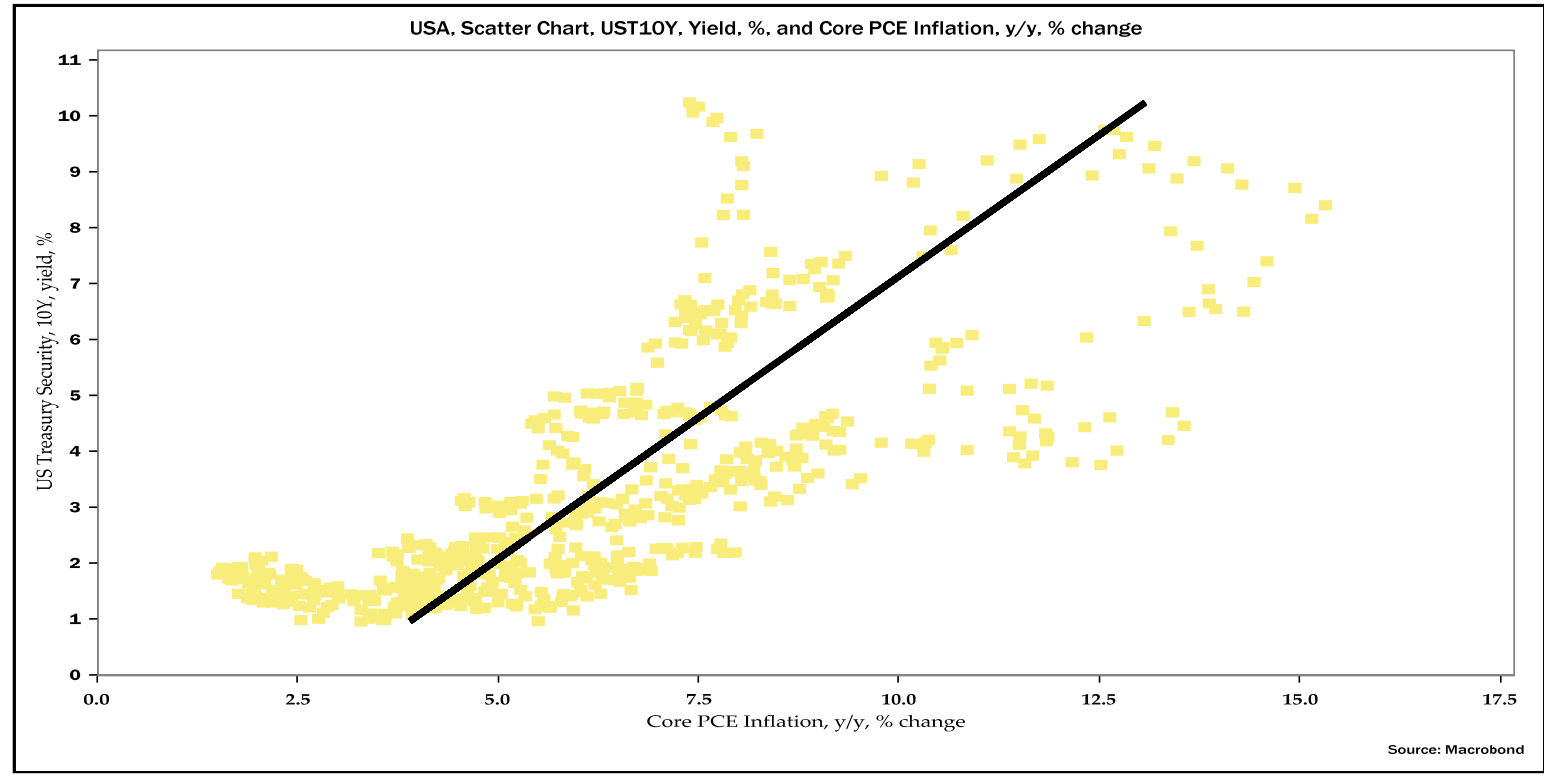

\section{A KEYNESIAN MODEL OF LONG-TERM INTEREST RATES}

\subsection{Keynes's View of the Determinants of Long-term Interest Rates}

Keynes (2007 [1936]) recognized that the ultimate foundation of interest rates lies in human psychology, social convention, and liquidity preference. Moreover, in Keynes's view the economy is characterized by ontological uncertainty (Davidson 2011,34-39) such that it is not possible for agents to assign probability to unknown outcomes and infer expected values of financial assets. Nevertheless, Keynes maintained that the central bank is the main driver of both short-term interest rates on Treasury bills and the nominal yields on long-term government bonds, noting that the central bank influences the long-term interest rates on government bonds mainly through influencing the short-term interest rates by setting the policy rates and deploying various monetary policy actions (Keynes 1930, 353; as citied in Kregel 2011,3). The short-term interest rates and the changes in the short-term interest rates are, respectively, the most important factors in determining the long-term interest rates and the changes in the long-term interest rates. Keynes's analysis of the relationship between short-term interest rates and long-term interest rates is based on Winfried Riefler's (1930) pioneering empirical and statistical analysis of interest rates on US government securities. 
Keynes (1930, 359-62; 2007 [1936], 152-53) opined that short-term realizations primarily drive the investor's long-term expectations because the investor often extrapolates the future outlook based on the present situation, as well as the past. Since, in Keynes's view, the investor cannot estimate the mathematical expectations of the unknown and uncertain future, the investor resorts to inferring the future from the present and the past conditions.

Keynes's view on the drivers of long-term interest rates is in contrast to the conventional view. The conventional view is that government financial variables, along with other macroeconomic variables, have a decisive influence, both statistically and economically, on government bonds' nominal yields, particularly in the long term. In this view, an increase (decrease) in the government debt ratio and/or the deterioration (improvement) of the government fiscal balance ratio are associated with higher (lower) government bond nominal yields. This view is widely expressed in the theoretical and empirical literature, such as Baldacci and Kumar (2010), Gruber and Kamin (2012), Lam and Tokuoka (2013), Poghoysan (2014), and Tokuoka (2012). Keynes's views on the role of the central bank in influencing long-term interest rate have support in contemporary macroeconomic theory. First, the champions of the fiscal theory of price level, as reflected in the Sims (2013) and Woodford (2001), arrive at a similar conclusion. Second, the proponents of modern money theory, such as Wray (2003 [1998] and 2012) and Tcherneva (2011), and other post-Keynesians, such as Lavoie (2014), also arrive at a view that gives the central bank a pivotal role in determining long-term interest rates on government bonds in countries with monetary sovereignty.

The quotes from Keynes, given below, illustrate his views on the determinants of long-term interest rates on government bonds:

- "[T]he influence of the short-term rate of interest on the long-term rate is much greater than anyone [...] would have expected" $(1930,315)$.

- "[T]here is no reason to doubt the ability of a central bank to make its short-term rate of interest effective in the market" $(1930,324)$.

- Even for well-informed investors, decisions about investments tend to be "oversensitive $[\ldots]$ to the near future" because "in truth, we know almost nothing about the more remote 
future." "[T]he ignorance about $[\ldots]$ the remote future is much greater than knowledge" about the current state of affairs. Hence, investors are "forced to seek a clue mainly here to trends further ahead." Moreover, "as long as a crowd can be relied on to act in a certain way, even if it is misguided, it will be to the advantage of the better informed professional to act in the same way - a short period ahead" (1930,357-58).

- "It is reasonable $[\ldots]$ to be guided to a considerable degree by the facts about which we feel somewhat confident, even though they may be less decisively relevant to the issues than other facts about which our knowledge is vague and scant. For this reason the facts of the existing situation enter, in a sense disproportionately, into the formation of our long-term expectations; our usual practice being to take the exiting situation and to project it into the future, modified only to the extent that we have more or less definite reasons for expecting a change" (2007 [1936], 148).

- " $[\mathrm{T}] \mathrm{h}$ he rate of interest cannot be a return to saving or waiting as such. On the contrary $[\ldots]$ the rate of interest is the reward for parting with liquidity for a specified period" (2007 [1936], 166-67).

- "The quantity of money $[\ldots]$ in conjunction with liquidity preference, determines that actual rate of interest in given circumstances" (2007 [1936], 167-68).

\subsection{A Simple Keynesian Model}

A simple model of the long-term interest rate and changes in the long-term interest rate is used here. This model is based on Keynes's view, as interpreted in Akram (2014), Akram and Das (2014, 2016, 2017a, and 2017b), and Akram and Li (2016 and 2017). This section gives an intuitive description of the model. ${ }^{3}$ The crucial institutional assumption in this model is that of monetary sovereignty, as defined in Wray (2012).

The main advantages of relying on this model for understanding the determinants of government bond yields are twofold. First, it accurately reflects Keynes's view on the drivers and dynamics of interest rates for government bonds. Second, after controlling for other important variables it can be readily used to test whether the Keynesian view that the short-term interest rate is the key driver of the long-term interest rate is accurate in the short and long run.

\footnotetext{
${ }^{3}$ The interested reader can see the mathematical models in Akram and Li (2017).
} 
The variables for the model are as follows: the long-term interest rate; the short-term interest rate; the policy rate; the spread between the short-term interest rate and the policy rate; the forward interest rates; the future short-term interest rate; the term premium; the current inflation rate; the expected inflation rate; the current growth rate; the expected growth rate; and the government fiscal variable. The model is qualitatively described below.

The long-term interest rate depends on the short-term interest rate and an appropriate forward rate. The forward rate is a function of the future short-term interest rate and the term premium. But the function of the future short-term interest rate and the term premium, in turn, is equal to the function of the expected inflation and the expected growth rate. The short-term interest rate is the sum of the policy rate (set by the central bank) and a spread.

In a world characterized by rational expectations, the expected rate of inflation and the expected growth rate would, respectively, amount to the mathematical expectations of the possible growth rates and the possible rates of inflation. However, in a world characterized by ontological uncertainty, the probability of unknown events is incalculable and cannot be estimated (Davidson 2015, 16-21). Hence, under a Keynesian perspective, the investor resorts to conjecture about the expected rate of inflation and the expected growth rate from the current conditions. Current inflation provides the most reliable estimate for expected inflation. Similarly the current growth rate provides the best guess for the expected growth rate. The forward rate, thus, is a function of the current inflation rate and the current growth rate. The long-term interest rate depends on the short-term interest rate and the drivers of the forward rate. This implies that the long-term interest rate, under Keynesian assumptions, is a function of the short-term interest rate, the current rate of inflation, and the current growth rate. This also implies that the change in the long-term interest rate is a function of the change in the short-term interest rate, the change in the rate of inflation, and the change in the growth rate. The change in the short-term interest rate is the sum of the change in the policy rate set by the central bank and the change in the spread between the policy rate and the short-term interest rate. 
If the government fiscal variable also affects the long-term interest rate through influencing the forward rate, then these factors could be accommodated in this model as well. The long-term interest rate is a function of the short-term interest rate, current inflation, the current growth rate, and the government fiscal variable. Likewise the change in the long-term interest rate is a function of the changes in the same variables.

The Keynesian model of government bond yields can be operationalized for empirical testing in simple terms. The long-term interest rate on government bonds can be modeled in terms of various combinations of several key macroeconomic and financial variables, such as the current short-term interest rate, the current rate of inflation, the pace of industrial production, the government fiscal variable, and other suitable control variables. The appropriate government fiscal variable is either the fiscal balance ratio or the government debt ratio.

\section{DATA}

\subsection{Data Description}

Time-series monthly data on short-term interest rates, long-term interest rates, inflation, economic growth, the government fiscal balance ratio, and business cycle conditions are used here. Short-term interest rates are obtained from the nominal yields on US Treasury bills of 3and 6-month tenors. Long-term interest rates are obtained from the nominal yields of long-term US Treasury securities of 2-, 5-, 7-, 10-, and 30-year tenors, based on constant maturity, as calibrated by the Federal Reserve. Inflation data are based on a two different measures of core inflation. Core inflation is defined as total inflation, excluding food and energy inflation. The pace of economic activity is calibrated by the year-over-year percentage changes in the seasonally adjusted measure of the index of industrial production. Business cycle conditions are represented by whether the economy is in a recession or not, in accordance with the National Bureau of Economic Research's (NBER) definition. 
Government fiscal data are obtained by taking the ratio of federal government net lending/borrowing (fiscal balance) to nominal GDP. It is calculated using the series of annualized federal fiscal balance ratios from monthly federal receipts and budget outlays, and the series from monthly nominal GDP. A measure of federal balance ratios is constructed using a number of steps. First, a seasonally adjusted federal fiscal balance series is created by applying a seasonal adjustment to the monthly non-seasonally adjusted federal fiscal balance series. Second, a measure of monthly nominal GDP is constructed by applying the PCE deflator to the StockWatson measure of the monthly real GDP series available from NBER. The numerator is the federal fiscal balance, while the denominator is the nominal GDP in the federal fiscal balance ratio. A positive (negative) federal fiscal balance indicates fiscal surplus (deficit).

Table 1 summarizes the variables and the data used in the econometric models. The first column gives the variable labels. The second column provides the variable description. The third column gives the original frequency; it also states if the data have been converted to a lower frequency. The final column lists both the primary and secondary sources. 
Table 1: Summary of the Data and the Variables

\begin{tabular}{|c|c|c|c|}
\hline $\begin{array}{l}\text { Variable } \\
\text { Labels }\end{array}$ & Data Description, Date Range & Frequency & Sources \\
\hline \multicolumn{4}{|c|}{ Short-term Interest Rates } \\
\hline TB3M & $\begin{array}{l}\text { Treasury bill, } 3 \text { month, secondary market, } \\
\text { discount rate, } \%\end{array}$ & Monthly & $\begin{array}{l}\text { Federal Reserve; } \\
\text { Macrobond }\end{array}$ \\
\hline TB6M & $\begin{array}{l}\text { Treasury bill, } 6 \text { month, secondary market, } \\
\text { discount rate, } \%\end{array}$ & Monthly & $\begin{array}{l}\text { Federal Reserve; } \\
\text { Macrobond }\end{array}$ \\
\hline \multicolumn{4}{|c|}{ US Treasury Securities Yields } \\
\hline GB2Y & $\begin{array}{l}\text { Treasury security, constant maturity, } 2 \text { year, } \\
\text { yield, average of period, } \%\end{array}$ & Monthly & $\begin{array}{l}\text { Federal Reserve; } \\
\text { Macrobond }\end{array}$ \\
\hline GB5Y & $\begin{array}{l}\text { Treasury security, constant maturity, } 5 \text { year, } \\
\text { yield, average of period, \% }\end{array}$ & Monthly & $\begin{array}{l}\text { Federal Reserve; } \\
\text { Macrobond }\end{array}$ \\
\hline GB7Y & $\begin{array}{l}\text { Treasury security, constant maturity, } 7 \text { year, } \\
\text { yield, average of period, } \%\end{array}$ & Monthly & $\begin{array}{l}\text { Federal Reserve; } \\
\text { Macrobond }\end{array}$ \\
\hline GB10Y & $\begin{array}{l}\text { Treasury security, constant maturity, } 10 \text { year, } \\
\text { Yield, average of period, } \%\end{array}$ & Monthly & $\begin{array}{l}\text { Federal Reserve; } \\
\text { Macrobond }\end{array}$ \\
\hline GB30Y & $\begin{array}{l}\text { Treasury security, constant maturity, } 30 \text { year, } \\
\text { yield, average of period, } \%\end{array}$ & Monthly & $\begin{array}{l}\text { Federal Reserve; } \\
\text { Macrobond }\end{array}$ \\
\hline \multicolumn{4}{|c|}{ Rate of Core Inflation } \\
\hline CPI & $\begin{array}{l}\text { Consumer price index, all urban consumers, US } \\
\text { city average, all items less food \& energy, SA, } \\
\% \text { change, y/y }\end{array}$ & Monthly & $\begin{array}{l}\text { Bureau of Labor } \\
\text { Statistics; Macrobond }\end{array}$ \\
\hline PCE & $\begin{array}{l}\text { Personal consumption expenditures, excluding } \\
\text { food \& energy price index, SA, } \% \text { change, y/y }\end{array}$ & Monthly & $\begin{array}{l}\text { Bureau of Economic } \\
\text { Analysis; Macrobond }\end{array}$ \\
\hline \multicolumn{4}{|c|}{ Pace of Economic Activity } \\
\hline IP & Industrial production, index, $\mathrm{SA}, \%$ change, $\mathrm{y} / \mathrm{y}$ & Monthly & $\begin{array}{l}\text { Federal Reserve; } \\
\text { Macrobond }\end{array}$ \\
\hline \multicolumn{4}{|c|}{ Federal Government Fiscal } \\
\hline $\mathbf{V}$ & $\begin{array}{l}\text { Federal fiscal balance (net government } \\
\text { lending/borrowing) as a share of nominal GDP, } \\
\text { SA, \%; nominal GDP is based on total personal } \\
\text { consumption expenditure deflator }\end{array}$ & Monthly & $\begin{array}{l}\text { NBER; Macrobond; } \\
\text { calculated by authors }\end{array}$ \\
\hline \multicolumn{4}{|c|}{ Business Cycle Conditions } \\
\hline RECES & $\begin{array}{l}\text { Recession dummy, } 1=\text { Recession, } 0=\text { No } \\
\text { recession }\end{array}$ & Monthly & $\begin{array}{l}\text { NBER; New York } \\
\text { Federal Reserve; } \\
\text { Macrobond }\end{array}$ \\
\hline
\end{tabular}




\subsection{Unit Root Tests}

The stationarity properties in the time series are ascertained by performing the following unit root tests: the Augmented Dickey-Fuller (ADF) (Dickey and Fuller 1979 and 1981) and Phillips-Perron (PP) (Phillips and Perron 1988) tests. The tests are conducted on the variables in levels and first differences.

Tables $2 \mathrm{~A}$ and $2 \mathrm{~B}$ present the unit root test results of the nominal yields of US Treasury bills of a 3-month tenor $\left(r_{S T}\right)$, the yields of Treasury securities of a 10-year tenor $\left(r_{L T}\right)$, the core CPI inflation $\left(\pi_{t}\right)$, the growth in the seasonally adjusted measure of the index of industrial production $\left(g_{t}\right)$, and the ratio of the federal fiscal balance as a share of nominal GDP $\left(V_{t}\right) .^{4}$

\footnotetext{
${ }^{4}$ The results of the unit root tests on the nominal yields of Treasury bills of a 6-month tenor are consistent with the nominal yields of Treasury bills of a 3-month tenor. The results of the unit root tests on the yields of Treasury securities of 2-, 5-, 7-, and 30-year tenors are consistent with the yields of Treasury securities of a 10-year tenor. The results of the unit root tests on the CPI inflation rate are consistent with the PCE inflation rate. Those results are provided in appendix tables A1 and A2.
} 
Table 2A: Unit Root Tests (Level)

\begin{tabular}{|c|c|c|c|c|c|}
\hline \multicolumn{6}{|c|}{ Unit Root Tests (Level) } \\
\hline Variable & & Tests & Statis tic & P-value & Obs. \\
\hline \multirow{6}{*}{ R_ST } & \multirow[b]{2}{*}{ Trend } & $\mathrm{ADF}$ & -2.071 & 0.562 & 681 \\
\hline & & $\mathrm{PP}$ & -2.189 & 0.496 & 681 \\
\hline & \multirow{2}{*}{ No trend } & $\mathrm{ADF}$ & -1.527 & 0.520 & 681 \\
\hline & & $\mathrm{PP}$ & -1.679 & 0.442 & 681 \\
\hline & \multirow{2}{*}{$\begin{array}{c}\text { No trend, No } \\
\text { constant } \\
\end{array}$} & $\mathrm{ADF}$ & -1.145 & 0.423 & 681 \\
\hline & & $\mathrm{PP}$ & -1.151 & 0.343 & 681 \\
\hline \multirow{6}{*}{ R_LT } & \multirow{2}{*}{ Trend } & $\mathrm{ADF}$ & -1.464 & 0.841 & 681 \\
\hline & & $\mathrm{PP}$ & -3.226 & 0.079 & 681 \\
\hline & \multirow{2}{*}{ No trend } & $\mathrm{ADF}$ & -0.872 & 0.797 & 681 \\
\hline & & $\mathrm{PP}$ & -1.077 & 0.724 & 681 \\
\hline & \multirow{2}{*}{$\begin{array}{c}\text { No trend, No } \\
\text { constant } \\
\end{array}$} & $\mathrm{ADF}$ & -0.725 & 0.652 & 681 \\
\hline & & $\mathrm{PP}$ & -1.100 & 0.232 & 681 \\
\hline \multirow{6}{*}{ INF (CPI) } & \multirow{2}{*}{ Trend } & $\mathrm{ADF}$ & -1.709 & 0.747 & 681 \\
\hline & & $\mathrm{PP}$ & -2.567 & 0.295 & 681 \\
\hline & \multirow{2}{*}{ No trend } & $\mathrm{ADF}$ & -1.329 & 0.616 & 681 \\
\hline & & PP & -2.256 & 0.187 & 681 \\
\hline & \multirow{2}{*}{$\begin{array}{c}\text { No trend, No } \\
\text { constant }\end{array}$} & $\mathrm{ADF}$ & -0.731 & 0.452 & 681 \\
\hline & & $\mathrm{PP}$ & -1.337 & 0.212 & 681 \\
\hline \multirow{6}{*}{ IP } & \multirow{2}{*}{ Trend } & $\mathrm{ADF}$ & -5.987 & 0.000 & 681 \\
\hline & & PP & -5.488 & 0.000 & 681 \\
\hline & \multirow{2}{*}{ No trend } & $\mathrm{ADF}$ & -5.425 & 0.000 & 681 \\
\hline & & PP & -5.200 & 0.000 & 681 \\
\hline & \multirow{2}{*}{$\begin{array}{c}\text { No trend, No } \\
\text { constant }\end{array}$} & $\mathrm{ADF}$ & -4.095 & 0.000 & 681 \\
\hline & & PP & -4.589 & 0.000 & 681 \\
\hline \multirow{6}{*}{ V } & \multirow{2}{*}{ Trend } & $\mathrm{ADF}$ & -1.423 & 0.854 & 671 \\
\hline & & $\mathrm{PP}$ & -1.409 & 0.578 & 671 \\
\hline & \multirow{2}{*}{ No trend } & $\mathrm{ADF}$ & -1.456 & 0.555 & 671 \\
\hline & & PP & 0.808 & 0.992 & 671 \\
\hline & \multirow{2}{*}{$\begin{array}{c}\text { No trend, No } \\
\text { constant }\end{array}$} & $\mathrm{ADF}$ & -0.777 & 0.664 & 671 \\
\hline & & PP & -0.777 & 0.341 & 671 \\
\hline
\end{tabular}

Note: PP test, ADF test $\left(\mathrm{H}_{0}\right.$ : series has a unit root). The lag lengths in both ADF and PP tests are selected based on the AIC criteria, which range from lag 1 to lag 24. 
Table 2B: Unit Root Tests (First Difference)

\begin{tabular}{|c|c|c|c|c|c|}
\hline \multicolumn{6}{|c|}{ Unit Root Tes ts (First Diffe re nce) } \\
\hline Variable & & Tests & Statis tic & P-value & Obs. \\
\hline \multirow{6}{*}{$\Delta \mathbf{R} \_\mathbf{S T}$} & \multirow{2}{*}{ Trend } & $\mathrm{ADF}$ & -18.431 & 0.000 & 680 \\
\hline & & $\mathrm{PP}$ & -2.189 & 0.000 & 680 \\
\hline & \multirow{2}{*}{ No trend } & $\mathrm{ADF}$ & -18.431 & 0.000 & 680 \\
\hline & & $\mathrm{PP}$ & -1.679 & 0.000 & 680 \\
\hline & \multirow{2}{*}{$\begin{array}{l}\text { No trend, No } \\
\text { constant }\end{array}$} & $\mathrm{ADF}$ & -18.443 & 0.000 & 680 \\
\hline & & PP & -1.151 & 0.000 & 680 \\
\hline \multirow{6}{*}{$\Delta \mathbf{R} \_\mathbf{L T}$} & \multirow{2}{*}{ Trend } & $\mathrm{ADF}$ & -19.124 & 0.000 & 680 \\
\hline & & PP & -3.226 & 0.000 & 680 \\
\hline & \multirow{2}{*}{ No trend } & $\mathrm{ADF}$ & -19.090 & 0.000 & 680 \\
\hline & & $\mathrm{PP}$ & -1.077 & 0.000 & 680 \\
\hline & \multirow{2}{*}{$\begin{array}{c}\text { No trend, No } \\
\text { constant }\end{array}$} & $\mathrm{ADF}$ & -19.101 & 0.000 & 680 \\
\hline & & PP & -1.100 & 0.000 & 680 \\
\hline \multirow{6}{*}{$\Delta$ INF (CPI) } & \multirow{2}{*}{ Trend } & ADF & -19.649 & 0.000 & 680 \\
\hline & & PP & -2.567 & 0.000 & 680 \\
\hline & \multirow{2}{*}{ No trend } & ADF & -19.651 & 0.000 & 680 \\
\hline & & $\mathrm{PP}$ & -2.256 & 0.000 & 680 \\
\hline & \multirow{2}{*}{$\begin{array}{c}\text { No trend, No } \\
\text { constant }\end{array}$} & $\mathrm{ADF}$ & -19.665 & 0.000 & 680 \\
\hline & & $\mathrm{PP}$ & -1.337 & 0.000 & 680 \\
\hline \multirow{6}{*}{$\Delta \mathbf{I P}$} & \multirow{2}{*}{ Trend } & ADF & -18.399 & 0.000 & 680 \\
\hline & & $\mathrm{PP}$ & -3.488 & 0.000 & 680 \\
\hline & \multirow{2}{*}{ No trend } & ADF & -18.414 & 0.000 & 680 \\
\hline & & $\mathrm{PP}$ & -0.919 & 0.000 & 680 \\
\hline & \multirow{2}{*}{$\begin{array}{c}\text { No trend, No } \\
\text { constant }\end{array}$} & $\mathrm{ADF}$ & -18.427 & 0.000 & 680 \\
\hline & & $\mathrm{PP}$ & -0.925 & 0.000 & 680 \\
\hline \multirow{6}{*}{$\Delta \mathbf{V}$} & \multirow{2}{*}{ Trend } & $\mathrm{ADF}$ & -21.605 & 0.000 & 670 \\
\hline & & $\mathrm{PP}$ & -0.630 & 0.000 & 670 \\
\hline & \multirow{2}{*}{ No trend } & $\mathrm{ADF}$ & -21.535 & 0.000 & 670 \\
\hline & & $\mathrm{PP}$ & 0.808 & 0.000 & 670 \\
\hline & \multirow{2}{*}{$\begin{array}{c}\text { No trend, No } \\
\text { constant }\end{array}$} & $\mathrm{ADF}$ & -21.480 & 0.000 & 670 \\
\hline & & $\mathrm{PP}$ & 1.231 & 0.000 & 670 \\
\hline
\end{tabular}

Note: $\mathrm{PP}$ test, $\mathrm{ADF}$ test $\left(\mathrm{H}_{0}\right.$ : series has a unit root). The lag lengths in both ADF and PP tests are selected based on the AIC criteria, which range from lag 1 to lag 24.

As depicted in tables $2 \mathrm{~A}$ and $2 \mathrm{~B}$, all unit root tests yield remarkably similar results for variables $r_{L T}, r_{S T}, \pi_{t}, V_{t}$. Most of the variables are nonstationary in their levels but become stationary in their first differences. Thus, it can be concluded that those four series are I(1) at the 5 percent level of significance. However, the application of the ADF and PP tests for $I P_{t}$ reveals that this 
variable is stationary in both its levels and its first differences. Thus, the results of the unit root tests show that there is a mixture of $\mathrm{I}(1)$ and $\mathrm{I}(0)$ processes in the model. Therefore, the bounds testing procedure is more appropriate for analyzing the data than the Johansen cointegration method. This is exactly the method applied here for empirical estimations in the next section.

\section{EMPIRICAL APPROACH, FINDINGS, AND INTERPRETATIONS}

\subsection{Model Specification}

The bounds testing procedure to cointegration and error correction models within the ARDL framework $^{5}$ is the appropriate empirical approach for understanding the drivers of long-term US interest rates. The paper uses this method to examine the dynamic relations among the variables: namely, the short-term interest rates $\left(r_{S T}\right)$, the long-term interest rates $\left(r_{L T}\right)$, the rate of inflation $\left(\pi_{t}\right){ }^{6}$ the pace of economic activity $\left(I P_{t}\right)$, and the federal government fiscal balance ratio $\left(V_{t}\right)$.

The bounds testing procedure within the ARDL approach has certain distinct advantages over the conventional approaches. The conventional cointegration approaches, such as Engel-Granger (1987), Johansen (1988), and Johansen-Juselius (1990), are valid when the variables are I(1) series, which means that the first differences of these variables obtain a covariance stationary series. In contrast, the bounds testing procedure can be applied irrespective of the order of the integration as long as their orders are less than two. Since the variables in the models are either $\mathrm{I}(0)$ or $\mathrm{I}(1)$, this approach is relevant for the questions addressed in this paper. ${ }^{7}$

Following Pesaran, Shin, and Smith's (2001) procedure, consider an unrestricted error correction model (UECM), as given below: ${ }^{8}$

\footnotetext{
${ }^{5}$ Introduced by Pesaran and Shin (1999) and Pesaran, Shin, and Smith (1999 and 2001).

${ }^{6}$ The rate of core CPI inflation is used for the rate of inflation in the tables presented. Results are similar if the rate of core PCE inflation is used.

${ }^{7}$ See the tables in subsection 4.2 ("Unit Roots Tests") for further information.

${ }^{8}$ Since the coefficients of the one-period lagged error correction term are not restricted, the ARDL is a UECM, also called a conditional error correction model.
} 


$$
\Delta Y_{t}=\mu+\alpha t+\sum_{i=1}^{6} \lambda_{i} D U M_{i}+\sum_{i=1}^{\rho-1} \theta_{i}{ }^{\prime} \Delta Z_{t-i}+\varphi^{\prime} \Delta X_{t}+\phi Y_{t-1}+\gamma^{\prime} X_{t-1}+\varepsilon_{t}
$$

where $\Delta=(1-L)$ is the difference operator and $L$ is the lag operator; $Y_{t}$ is the long-term interest rates $\left(r_{L T}\right)$; and $X_{t}$ is a vector of explanatory variables. The explanatory variables include the short-term interest rates $\left(r_{S T}\right)$, the rate of inflation $\left(\pi_{t}\right)$, the pace of economic activity $\left(I P_{t}\right)$, and the federal government fiscal balance ratio $\left(V_{t}\right) ; Z_{t}$ is a vector of $Z_{t}=\left(Y_{t}, X_{t}{ }^{\prime}\right)^{\prime} ; \mu$ and $t$ denote the intercept and the time trend, respectively; $D U M_{i}$ is a vector of dummy variables to allow for structural breaks; and $\varepsilon_{t}$ is a vector of white-noise error terms.

\subsection{Model Estimation}

The model estimation process is comprised of the following four components:

1. Testing for a unit root in each series.

2. Testing for structural breaks.

3. Testing the cointegrating bounds test for the long-run equilibrium relationship.

4. Estimating the long-run equilibrium relationship and the multivariate short-run dynamic error correction model.

\subsubsection{Implications of the Unit Root Tests}

The unit root tests undertaken earlier have already shown that none of the variables are I(2). This enables the application of the bounds testing procedure to cointegration. If an I(2) series exists in the model, the bounds testing procedure would be inappropriate.

\subsubsection{Testing for Structural Breaks}

In the models with a long time series of macroeconomic variables, one way to improve the model's appropriateness and measures of statistical fit is to use dummy variables to capture the structural breaks. Thus, the specified UECM (equation 1) is estimated by augmenting the cointegrating equations with appropriate dummy variables. 
The potential structural breaks are explored with Gregory and Hansen's (1996) cointegration test, which extends Engle and Granger's (1987) procedure by allowing a structural break in either the intercept or the intercept and the cointegrating coefficient. This test assumes the null hypothesis of no cointegration against the alternative of cointegration with one structural break at an unknown time. In table 3, four models are implemented in accordance with Gregory and Hansen's (1996) approach:

1. Model C allows for the level shift only.

2. Model $\mathrm{C} / \mathrm{T}$ includes a time trend with the regime shift.

3. Model $\mathrm{C} / \mathrm{S}$ includes the regime shift where intercept and slope coefficients change.

4. Model $\mathrm{C} / \mathrm{S} / \mathrm{T}$ includes the regime shift where intercept, slope coefficients, and trend change.

Four algorithms are applied to choose the number of lags:

1. Model AIC chooses the number of lags that minimize the Akaike Information Criterion (AIC).

2. Model BIC chooses the number of lags that minimize the Bayesian Information Criterion (BIC).

3. Model DOWNT chooses the number of lags on the basis of a t-test. The maximum lag is set to 24 and then tests downward until the last lag of the first difference included is significant according to its t-statistic.

4. Model FIXED sets the number of lags equal to the maximum lags specified (24 lags).

Each of the models has a dummy variable to allow for a structural break. The dummy variable is set equal to zero before the breakpoint, which is determined endogenously. After the breakpoint, the dummy variable takes on the value of one. 
Table 3: Gregory and Hansen Cointegration Tests for Regime Shifts

\begin{tabular}{|c|c|c|c|c|c|c|c|c|}
\hline \multicolumn{9}{|c|}{ Gregory and Hansen Cointegration Tests for Regime Shifts } \\
\hline & \multicolumn{2}{|c|}{ Model AIC } & \multicolumn{2}{|c|}{ Model BIC } & \multicolumn{2}{|c|}{ Model DOWNT } & \multicolumn{2}{|c|}{ Model FIXED } \\
\hline & Test Stat. & Breakpoint & Test Stat. & Breakpoint & Test Stat. & Breakpoint & Test Stat. & Breakpoint \\
\hline \multicolumn{9}{|l|}{ ADF } \\
\hline Model C & $-5.56 * *$ & $2005 \mathrm{~m} 8$ & -5.18 & $1987 \mathrm{ml}$ & $-5.87 * *$ & $1995 \mathrm{~m} 8$ & $-6.16^{* * *}$ & $1980 \mathrm{~m} 12$ \\
\hline Model C/T & $-6.12 * *$ & $2004 \mathrm{~m} 2$ & -5.24 & $1987 \mathrm{ml}$ & $-6.22 * *$ & $1971 \mathrm{ml}$ & $-6.25 * *$ & $1980 \mathrm{~m} 12$ \\
\hline Model C/S & -5.64 & $1987 \mathrm{~m} 11$ & $-6.57^{* k}$ & $1995 \mathrm{~m} 7$ & $-6.93 * * *$ & $2005 \mathrm{~m} 2$ & $-6.22 *$ & $2005 \mathrm{~m} 2$ \\
\hline Model C/S/T & $-7.69 * * *$ & $1985 \mathrm{~ms}$ & $7.25^{* *}$ & $1967 \mathrm{mg}$ & $-7.45 * * *$ & $1975 \mathrm{mll}$ & $-8.16 * * *$ & $1985 \mathrm{~m} 5$ \\
\hline \multicolumn{9}{|l|}{$\mathrm{Zt}$} \\
\hline Model C & $-6.06 * *$ & $2005 \mathrm{~m} 2$ & $-5.58^{* k}$ & $1982 \mathrm{ml} 0$ & $-6.25 * * *$ & $1995 \mathrm{~m} 6$ & $-6.7 * * *$ & $2005 \mathrm{~m} 2$ \\
\hline Model C/T & $-6.6^{* * *}$ & $1981 \mathrm{~m} 4$ & -5.44 & $1987 \mathrm{ml1}$ & $-6.9 * * *$ & $1971 \mathrm{~m} 10$ & $-7.08 * * *$ & $1981 \mathrm{~m} 4$ \\
\hline Model C/S & -6.16 & $1988 \mathrm{ml}$ & $-7.03^{* * k}$ & $1995 \mathrm{~m} 6$ & $-7.87 * * *$ & $1998 \mathrm{~ms}$ & $-6.99 * * *$ & $1998 \mathrm{~m} 8$ \\
\hline Model C/S/T & $-7.99 * * *$ & $1985 \mathrm{~ms}$ & $-7.43^{* * *}$ & $1968 \mathrm{~ms}$ & $-7.63 * * *$ & $1976 \mathrm{~m} 2$ & $-8.38 * * *$ & $1985 \mathrm{~m} 8$ \\
\hline \multicolumn{9}{|l|}{$\mathrm{Za}$} \\
\hline Model C & $-57.81 *$ & $2005 \mathrm{~m} 2$ & -49.05 & $1982 \mathrm{ml0}$ & $-61.55^{* *}$ & $1995 \mathrm{mb}$ & $-61.83 * *$ & $2005 \mathrm{~m} 2$ \\
\hline Model C/T & $-70.53^{* *}$ & $1981 \mathrm{~m} 4$ & -43.27 & $1987 \mathrm{ml1}$ & $-72.73^{* *}$ & $1971 \mathrm{ml}$ & $-79.21 * * *$ & $1981 \mathrm{~m} 4$ \\
\hline Model C/S & -55.12 & $1988 \mathrm{ml}$ & -74.44 & $1995 \mathrm{~m} 6$ & $-83.45^{* *}$ & $1998 \mathrm{~ms}$ & -75.02 & $1998 \mathrm{~m} 8$ \\
\hline Model C/S/T & $-94.1 * *$ & $1985 \mathrm{~ms}$ & -77.25 & $1968 \mathrm{~ms}$ & $-87.88 *$ & $1976 \mathrm{~m} 2$ & $-102.21 * * *$ & $1985 \mathrm{~ms}$ \\
\hline
\end{tabular}

Note 1: Following Gregory and Hansen (1996), model C specifies a break in the constant term; model C/T specifies a break in the constant and the trend; model $\mathrm{C} / \mathrm{S}$ specifies a break in the constant and the slope; model $\mathrm{C} / \mathrm{S} / \mathrm{T}$ specifies a break in the constant, the slope, and the trend. Model AIC: lags chosen by Akaike Information Criterion; model BIC: lags chosen by Bayesian Information Criterion; model DOWNT: downward t lag selection; and model FIXED: sets the number of lags equal to 24 .

Note 2: $*, * *$, and $* * *$ indicate significance at 1 percent, 5 percent, and 10 percent, respectively.

Note 3: Critical values are taken from Gregory and Hansen (1996), which are tabulated by modifying the MacKinnon (1991) procedure.

The results in table 3 show that the null hypothesis of no cointegration is rejected by most models. This implies that one or more structural changes are present in the long-run cointegration equation. The breakpoints are selected where the test statistic is at the minimum or, in other words, the absolute ADF and PP test statistics are at their maximum. Accordingly, 16 breakpoints are picked from the results of table $3 .^{9}$

\footnotetext{
${ }^{9}$ The 16 breakpoints for all models: $1967 \mathrm{~m} 9 ; 1968 \mathrm{~m} 8 ; 1971 \mathrm{~m} 1 ; 1975 \mathrm{~m} 11 ; 1976 \mathrm{~m} 2 ; 1980 \mathrm{~m} 12 ; 1981 \mathrm{~m} 4 ; 1982 \mathrm{~m} 10$; 1985m5; 1985m8; 1995m6; 1995m7; 1998m8; 2004m2; 2005m2; and 2005m8.
} 
To select the best possible breakpoints, the modified Chow break test ${ }^{10}$ is applied to all 16 dates separately. In table 4, the three functional forms are specified as follows:

1. Type 1 includes independent variables (X) and a dummy variable (DUM).

2. Type 2 includes $X$ and the cross product of each independent variable times the dummy variables (DX).

3. Type 3 includes X, DUM, and DX.

Subsequently each breakpoint is checked one by one using three function forms, where each date is treated as a known breakpoint.

Among the 16 breakpoints, five breaks are significant in most of the cases. Four of the five structural breaks are in the early 1980s, which confirms the spike in both long-term and shortterm interest rates in the early 1980s, as shown in figures 1 and 2 . One of the structural breaks occurs in 2005. This is in line with the rise in short-term interest rates before the onset of the Global Financial Crisis, as displayed in figure 2. Table 4 reports the F-statistic with p-values near zero for the Chow test of the stability of the coefficient estimates using those five dates as the breakpoints. The results reveal that under the null hypothesis of coefficient constancy, one can reject the null hypothesis for all five dates specified. The probabilities of the F-statistic for the Chow test of the stability of the coefficient estimates are larger than 0.05 using the other 11 dates as the breakpoints, showing that the coefficients remained constant for the two sample periods. Overall, testing various dates in the endogenously determined multiple break test and the modified Chow break test, one can augment the cointegrating equation with five dummy variables for the following breakpoints—1980m12; 1981m4; 1982m10; 1985m5; and 2005m2together with the recession dummy, which takes on values of 1 during episodes of recessions. ${ }^{11}$

\footnotetext{
${ }^{10}$ Proposed by Shehata (2011).

${ }^{11}$ The recession data comes from NBER's webpage for US Business Cycle Expansions and Contractions, http:/www.nber.org/cycles.html (accessed July 21, 2017). All six dummy variables are considered as exogenous variables during estimations.
} 
Table 4: Chow Tests and Structural Change Regressions

\begin{tabular}{|c|c|c|c|c|c|}
\hline \multicolumn{6}{|c|}{ Chow Test and Structural Change Regressions } \\
\hline & DUM80m12 & DUM81m4 & DUM82m10 & DUM85m5 & DUM05m2 \\
\hline & Chow test_2 & Chow test_3 & Chow test_2 & Chow test_2 & Chow test_1 \\
\hline \multirow{2}{*}{ R_ST } & $0.508 * * *$ & $0.488 * * *$ & $0.733 * * *$ & $0.752 * * *$ & $0.761 * * *$ \\
\hline & {$[0.04]$} & {$[0.04]$} & {$[0.03]$} & {$[0.02]$} & {$[0.02]$} \\
\hline \multirow{2}{*}{ IP } & 0.014 & $-0.0128 * *$ & $-0.035 * * *$ & $-0.035 * * *$ & $-0.027 * * *$ \\
\hline & {$[0.01]$} & {$[0.01]$} & {$[0.01]$} & {$[0.01]$} & {$[0.01]$} \\
\hline \multirow{2}{*}{ INF } & $0.264 * * *$ & $0.249 * * *$ & $0.092 * *$ & $0.054 *$ & $0.041 *$ \\
\hline & {$[0.04]$} & {$[0.03]$} & {$[0.03]$} & {$[0.02]$} & [0.02] \\
\hline \multirow{2}{*}{$\mathbf{V}$} & $-0.369 * * *$ & $-0.337 * * *$ & $-0.570 * * *$ & $-0.632 * * *$ & $-0.319 * * *$ \\
\hline & {$[0.05]$} & {$[0.05]$} & {$[0.04]$} & {$[0.03]$} & {$[0.01]$} \\
\hline \multirow{2}{*}{ CONSTANT } & $1.663 * * *$ & $2.019 * * *$ & $1.252 * * *$ & $1.319 * * *$ & $2.033 * * *$ \\
\hline & {$[0.09]$} & {$[0.14]$} & {$[0.09]$} & {$[0.09]$} & {$[0.09]$} \\
\hline \multirow{2}{*}{ DUM } & & $-0.704 * * *$ & & & $-1.496 * * *$ \\
\hline & & {$[0.17]$} & & & {$[0.1]$} \\
\hline \multirow{2}{*}{ DUM*R_ST } & $0.302 * * *$ & $0.302 * * *$ & 0.023 & $-0.148 * * *$ & \\
\hline & {$[0.05]$} & {$[0.04]$} & {$[0.04]$} & {$[0.04]$} & \\
\hline \multirow{2}{*}{ DUM*IP } & -0.002 & 0.02 & $0.063 * * *$ & $0.066^{* * *}$ & \\
\hline & {$[0.02]$} & {$[0.02]$} & {$[0.01]$} & {$[0.01]$} & \\
\hline \multirow{2}{*}{ DUM*INF } & -0.095 & 0.041 & $0.309 * * *$ & $0.545^{* * *}$ & \\
\hline & {$[0.06]$} & {$[0.06]$} & {$[0.07]$} & {$[0.07]$} & \\
\hline \multirow{2}{*}{ DUM*V } & $0.208 * * *$ & $0.164 * *$ & $0.425 * * *$ & $0.545^{* * *}$ & \\
\hline & {$[0.05]$} & {$[0.05]$} & {$[0.05]$} & {$[0.03]$} & \\
\hline \multirow[t]{2}{*}{ Obs. } & 672 & 672 & 672 & 672 & 672 \\
\hline & $\begin{array}{r}1960 \mathrm{M} 01- \\
2015 \mathrm{M} 12 \\
\end{array}$ & $\begin{array}{r}1960 \mathrm{M} 01- \\
2015 \mathrm{M} 12 \\
\end{array}$ & $\begin{array}{r}1960 \mathrm{M} 01- \\
2015 \mathrm{M} 12 \\
\end{array}$ & $\begin{array}{r}1960 \mathrm{M} 01- \\
2015 \mathrm{M} 12 \\
\end{array}$ & $\begin{array}{r}1960 \mathrm{M} 01- \\
2016 \mathrm{M} 11 \\
\end{array}$ \\
\hline Adj R-squared & 0.9187 & 0.9248 & 0.9202 & 0.91 & 0.9187 \\
\hline Chow test statis tics & 54.554 & 58.3203 & 56.7358 & 73.9292 & 209.1123 \\
\hline
\end{tabular}

Note 1: $* * *$, and $* * *$ indicate significance at 1 percent, 5 percent, and 10 percent, respectively

Note 2: Chow test types: $\mathrm{Y}=\mathrm{X}+\mathrm{DUM} ; \mathrm{Y}=\mathrm{X}+\mathrm{DX}$; and $\mathrm{Y}=\mathrm{X}+\mathrm{DUM}+\mathrm{DX}$, where: $\mathrm{DUM}=$ Dummy variable $(0,1)$, takes $(0)$ in first period, and (1) in second period. $\mathrm{DX}=$ Cross product of each $\mathrm{Xi}$ times DUM. 


\subsubsection{Bounds Test Procedure to Cointegration}

The next stage of the analysis is the bounds testing procedure. The following ARDL $\left(p, q_{1}, q_{2}, q_{3}, q_{4}\right)$ model is estimated for each long-term interest rate: ${ }^{12}$

$$
\begin{aligned}
& \Delta r_{L T t}=\mu+\alpha t+\sum_{i=1}^{6} \lambda_{i} D U M_{i}+\sum_{i=1}^{P} \theta_{1 i} \Delta r_{L T t-i}+\sum_{j=1}^{q_{1}} \theta_{2 j} \Delta r_{S T t-j}+\sum_{l=1}^{q_{2}} \theta_{3 l} \Delta \pi_{t-l} \\
& +\sum_{m=1}^{q_{3}} \theta_{4 m} \Delta I P_{t-m}+\sum_{p=1}^{q_{4}} \theta_{5 p} \Delta V_{t-p}+\phi r_{L T t-1}+\gamma_{1} r_{S T t-1}+\gamma_{2} \pi_{t-1}+\gamma_{3} I P_{t-1}+\gamma_{4} V_{t-1}+\varepsilon_{t}
\end{aligned}
$$

The order of the lags $\left(p, q_{1}, q_{2}, q_{3}, q_{4}\right)$ in the bounds testing procedure are selected using the AIC. As monthly data are used, the maximum number of lags is set equal to 24 (two years). The null hypothesis $\left(H_{0}\right)$ of no cointegration and the alternative hypothesis $\left(H_{a}\right)$ of cointegration are as follows:

$$
\begin{aligned}
& H_{0}: \phi=\gamma_{1}=\gamma_{2}=\gamma_{3}=\gamma_{4}=0 ; \\
& H_{a}: \phi \neq \gamma_{1} \neq \gamma_{2} \neq \gamma_{3} \neq \gamma_{4} \neq 0 .
\end{aligned}
$$

Since the F-test utilized in the bounds test has a nonstandard distribution, two bounds of critical values for a sample size of 1,000 based on 40,000 replications of a stochastic stimulation from Pesaran, Shin, and Smith (2001) ${ }^{13}$ are used. As a cross check, the t-ratios of the bounds testing procedure for lagged long-term interest rates are also used. Under the null hypothesis of the ttest, the coefficient of lagged long-term interest rates $(\phi)$ is zero. Under the alternative hypothesis, it falls into the range $[-1,0]$.

\footnotetext{
${ }^{12}$ Five long-term interest rates are used in this paper: the yields of Treasury securities of 2-, 5-, 7-, 10-, and 30-year tenors. The key results using the yields of 10-year Treasury securities are discussed at length in the paper, while additional results are available in the appendix.

${ }^{13}$ Here the sample size is 662 .
} 
Based on the assumptions made by Pesaran, Shin, and Smith (2001), five models are specified for testing the cointegrating bounds test (see table 5):

1. Model 1 contains no intercepts and no trends $(\mu=\alpha=0)$.

2. Model 2 contains restricted intercepts and no trends $\left(\mu=-\left(\phi, \gamma^{\prime}\right) v, \alpha=0\right) .{ }^{14}$

3. Model 3 contains unrestricted intercepts and no trends $(\mu \neq 0, \alpha=0)$.

4. Model 4 contains unrestricted intercepts and restricted trends $\left(\mu \neq 0, \alpha=-\left(\phi, \gamma^{\prime}\right) v\right)$.

5. Model 5 contains unrestricted intercepts and unrestricted trends $(\mu \neq 0, \alpha \neq 0)$.

As table 5 indicates, since the calculated F-statistics fall above the upper critical value, the null hypothesis of no long-run equilibrium relationship is easily rejected at the 1 percent significance level for all five models and long-term interest rates. ${ }^{15}$ For models 1,3 , and 5, the t-ratios of the bounds testing procedure clearly reject a zero coefficient of lagged long-term interest rates at the 1 percent significance level. Thus, one may conclude that the null hypothesis of no long-run equilibrium relationship for each long-term interest rate is conclusively rejected.

\footnotetext{
${ }^{14} v$ is the unknown $(\mathrm{k}+1)$-vectors of intercepts of the data-generating process for $\left\{Z_{t}\right\}_{t=1}^{\infty}$.

${ }^{15}$ According to Pesaran, Shin, and Smith (1999), if the F-statistic falls above an upper critical value, the null hypothesis is rejected. The opposite is the case if the F-statistic falls below a lower critical value. If the F-statistic falls between the lower and upper critical values, the result is inconclusive.
} 
Table 5: Bounds Tests of Levels Relationship

\begin{tabular}{|c|c|c|c|c|c|c|c|c|c|c|}
\hline \multicolumn{11}{|c|}{ Bounds Tests of Levels Relationship } \\
\hline & \multicolumn{2}{|c|}{ Model 1} & \multicolumn{2}{|c|}{ Model 2} & \multicolumn{2}{|c|}{ Model 3} & \multicolumn{2}{|c|}{ Model 4} & \multicolumn{2}{|c|}{ Model 5} \\
\hline$K=4$ & F-test & t-test & F-test & t-test & F-test & t-test & F-test & t-test & F-test & t-test \\
\hline GB30Y & $7.761 * * *$ & $-5.903 * * *$ & $7.476^{* * *}$ & & $8.926 * * *$ & $-6.291 * * *$ & $9.834 * * *$ & & $11.709 * * *$ & $-7.394 * * *$ \\
\hline GB10Y & $7.426 * * *$ & $-5.660 * * *$ & $9.145 * * *$ & & $10.945 * * *$ & $-7.046 * * *$ & $9.425 * * *$ & & $11.223 * * *$ & $-7.077 * * *$ \\
\hline GB7Y & $7.611 * * *$ & $-5.835 * * *$ & $8.06 * * *$ & & $9.972 * * *$ & $-6.621 * * *$ & $9.363 * * *$ & & $11.105 * * *$ & $-7.168 * * *$ \\
\hline GB5Y & $7.624 * * *$ & $-5.714 * * *$ & $9.394 * * *$ & & $11.263 * * *$ & $-7.252 * * *$ & $10.182 * * *$ & & $12.144 * * *$ & $-7.423 * * *$ \\
\hline GB2Y & $7.636 * * *$ & $-5.537 * * *$ & $6.349 * * *$ & & $7.609 * * *$ & $-5.353 * * *$ & $9.521 * * *$ & & $11.280 * * *$ & $-6.754 * * *$ \\
\hline \multicolumn{11}{|c|}{ F-statistic } \\
\hline Critical V & Lower BV & Upper BV & Lower BV & Upper BV & Lower BV & Upper BV & Lower BV & Upper BV & Lower BV & Upper BV \\
\hline $1.0 \%$ & 3.07 & 4.44 & 3.29 & 4.37 & 3.74 & 5.06 & 3.81 & 4.92 & 4.40 & 5.72 \\
\hline $2.5 \%$ & 2.62 & 3.90 & 2.88 & 3.87 & 3.25 & 4.49 & 3.40 & 4.36 & 3.89 & 5.07 \\
\hline $5.0 \%$ & 2.26 & 3.48 & 2.56 & 3.49 & 2.86 & 4.01 & 3.05 & 3.97 & 3.47 & 4.57 \\
\hline $10.0 \%$ & 1.90 & 3.01 & 2.20 & 3.09 & 2.45 & 3.52 & 2.68 & 3.53 & 3.03 & 4.06 \\
\hline \multicolumn{11}{|c|}{ t-s tatistic } \\
\hline Critical V & Lower BV & Upper BV & Lower BV & Upper BV & Lower BV & Upper BV & Lower BV & Upper BV & Lower BV & Upper BV \\
\hline $1.0 \%$ & -2.58 & -4.23 & & & -3.43 & -4.60 & & & -3.96 & -4.96 \\
\hline $2.5 \%$ & -2.24 & -3.89 & & & -3.13 & -4.26 & & & -3.65 & -4.62 \\
\hline $5.0 \%$ & -1.95 & -3.60 & & & -2.86 & -3.99 & & & -3.41 & -4.36 \\
\hline $10.0 \%$ & -1.62 & -3.26 & & & -2.57 & -3.66 & & & -3.13 & -4.04 \\
\hline
\end{tabular}

Note 1: Following Pesaran, Shin, and Smith (2001), five models are considered with appropriate critical values: model 1, no constant, no trend; model 2, restricted constant, no trend; model 3, unrestricted constant, no trend; model 4, unrestricted constant, restricted trend; model 5, unrestricted constant, unrestricted trend.

Note 2: $* * *$ indicates significance at 1 percent.

Note 3: $\mathrm{k}$ : \# of nondeterministic regressors in long-run relationship.

Note 4: Critical values are cited from Pesaran, Shin, and Smith (2001).

\subsubsection{Vector Error Correction Model and Its Interpretation}

With the acceptance of a significant long-run equilibrium relationship among short-term interest rates, inflation rates, the pace of economic activity, the government fiscal balance ratio, and long-term interest rates, the next step is the estimation of a multivariate vector error correction (VEC) model.

The VEC model has two important features. First, it can be used for estimating short-run coefficients by restricting long-run relationships through their cointegrating equations. Second, the error correction term that provides the feedback or the speed of adjustment tells how deviations from the long-run equilibrium adjust over time. ${ }^{16}$

\footnotetext{
${ }^{16}$ Since the lagged error correction term is derived from the long-run cointegration relationship(s), the significance of the lagged error correction term(s) will indicate the long-run causal relationship.
} 
Tables 6A and 6B present the estimation of the corresponding VEC models that have been specified for testing the cointegrating bounds test. ${ }^{17}$ Table $6 \mathrm{~A}$ provides the long-run coefficients of the estimated models, while table $6 \mathrm{~B}$ provides the short-run coefficients of same models. (The long- and short-run coefficients of these models are provided in separate tables due to space constraints). The results show that in all five models, the main variables - such as short-term interest rates, the rate of inflation, and the pace of economic activity — are positively correlated with the long-term interest rates, with the estimated elasticities of $0.44-0.60,0.34-0.46$, and 0.05-0.12, respectively. Specifically, a 1 percentage point increase in the short-term interest rate, the rate of inflation, and the pace of economic activity respectively causes a long-run increase of around 44 basis points (bps) to 60bps, 34bps to $46 \mathrm{bps}$, and $5 \mathrm{bps}$ to $12 \mathrm{bps}$ in the long-term interest rate.

These empirical results are in concordance with the theoretical conjectures made earlier. First, they show that higher (lower) short-term interest rates lead to higher (lower) long-term interest rates on Treasury securities. Second, they show that an increase (decrease) in the rate of inflation leads to higher (lower) inflation, implying that investors seek to be compensated for holding long-term Treasury securities when current inflation rises. Third, the results also show that as the pace of economic activity increases (decreases), long-term interest rates on Treasury securities rise. This could be due to several reasons. First, the Fed may tighten (loosen) monetary policy and raise (lower) short-term interest rates as the pace of economic activity picks up (slows down). Second, the rate of inflation may rise (fall) as the pace of economic activity increases (declines). Third, a higher (lower) pace of economic activity can indicate higher (lower) risk taking.

The results obtained also show that an increase (decline) in the federal government fiscal balance ratio lowers (raises) long-term interest rates on Treasury securities. The increase in the federal government fiscal balance ratio means either the ratio of fiscal surplus to nominal GDP widens or the ratio of the fiscal deficit to nominal GDP narrows. The implication is that improvement

\footnotetext{
${ }^{17}$ In table 6, the yields of Treasury securities of a 10-year tenor are used as the long-term interest rates. In appendix tables A3-A6, the yields of Treasury securities of 2-, 5-, 7-, and 30-year tenors are used as the long-term interest rates.
} 
(deterioration) of the federal fiscal balance lowers (raises) government bond yields. These findings are quite relevant for economic policy and macroeconomic theory. The effect of a 1 percentage point increase in the ratio of fiscal balance to nominal GDP leads to a decline in the long-term interest rate that ranges from $11 \mathrm{bps}$ to $16 \mathrm{bps}$. It shows that while the federal fiscal balance has a statistically significant effect on government bond yields, its economic effect pales in comparison to that of short-term interest rates and the rate of inflation. It also provides a valuable empirical perspective on the debate about the macroeconomic effects of the government fiscal balance ratio, government spending, and government borrowing on benchmark policy rates, the money market, and the government bond market. These topics have been the subject of lively theoretical debates and contentions in Akram and Li (2016 and 2017), Baladacci and Kumar (2010), Bindseil (2004), Fullwiler (2016), Gruber and Kamin (2012), Lavoie (2009 [2007] and 2014), Poghosyan (2014), Reinhart and Rogoff (2009), and Wray (2003 [1998] and 2012).

The coefficients of the error correction term in the long-term interest rate equation are significant at the 1 percent level with the expected negative sign. This confirms the results of the bounds test for cointegration. The coefficients of the error correction term are around - 0.1 . This implies that about 10 percent of disequilibria caused by shocks on short-term interest rates, inflation, economic activity, and the government fiscal balance ratio is corrected within one month.

The results of the short-run error correction model are presented in the panel of short-run coefficients in table 6B. Most of the short-run coefficients are significant, except for a few lagged differences in short-term interest rates. The signs of the short-run dynamic impacts are consistent with the long-run results; however, the short-run effects are quite small, around 10 percent of the long-run effects. Regarding the ratio of the government fiscal balance, it has a significantly negative impact on long-term interest rates in the short run, which is in line with the results of the long-run estimation.

Moreover, the results in tables $6 \mathrm{~A}$ and $6 \mathrm{~B}$ indicate that the coefficients of most dummy variables are statistically significant. This further justifies the choice of the dummy variables. Overall, the estimates of the short-run error correction model provide further direct evidence of the 
complicated dynamics that exist among short-term interest rates, inflation rates, the pace of economic activity, the government fiscal balance ratio, and long-term interest rates with regards to US Treasury securities.

Table 6A: Estimated Long-run Coefficients of Models Using the ARDL Approach (with GB10Y)

\begin{tabular}{|c|c|c|c|c|c|}
\hline \multicolumn{6}{|c|}{ Es timated Long-run Coefficients of Models using the ARDL Approach } \\
\hline \multicolumn{6}{|c|}{ (with GB10Y) } \\
\hline & Model 1 & Model 2 & Model 3 & Model 4 & Model 5 \\
\hline \multicolumn{6}{|c|}{ Long-run Coefficients } \\
\hline \multirow{2}{*}{ R_ST } & $0.5991 * * *$ & $0.5145 * * *$ & $0.5145 * * *$ & $0.4402 * * *$ & $0.4402 * * *$ \\
\hline & [0.1] & {$[0.07]$} & [0.07] & [0.09] & [0.09] \\
\hline \multirow{2}{*}{ INF } & $0.457 * * *$ & $0.3386^{* * *}$ & $0.3386^{* * *}$ & $0.4205^{* * *}$ & $0.4205^{* * *}$ \\
\hline & {$[0.1]$} & {$[0.07]$} & {$[0.07]$} & [0.09] & {$[0.09]$} \\
\hline \multirow{2}{*}{$\mathbf{V}$} & $-0.1673 * *$ & $-0.1422 * * *$ & $-0.1422 * * *$ & $-0.1119 * *$ & $-0.1119 * *$ \\
\hline & {$[0.07]$} & {$[0.04]$} & [0.04] & {$[0.05]$} & {$[0.05]$} \\
\hline \multirow{2}{*}{ IP } & $0.1176^{* * *}$ & $0.0469 * *$ & $0.0469 * *$ & $0.0481^{* *}$ & $0.0481 * *$ \\
\hline & {$[0.03]$} & {$[0.02]$} & [0.02] & {$[0.02]$} & {$[0.02]$} \\
\hline \multirow{2}{*}{ DUM80M12 } & $4.634 * *$ & $3.5162 * * *$ & $3.5162 * * *$ & $3.8819 * * *$ & $3.8819^{* * *}$ \\
\hline & [2.05] & [1.31] & [1.31] & {$[1.34]$} & {$[1.34]$} \\
\hline \multirow{2}{*}{ DUM81M4 } & $-4.0904 *$ & -1.8317 & -1.8317 & -1.5782 & -1.5782 \\
\hline & [2.05] & [1.43] & [1.43] & [1.42] & [1.42] \\
\hline \multirow{2}{*}{ DUM82M10 } & $2.2047 * *$ & $1.288 *$ & $1.288 *$ & $1.474 * *$ & $1.474 * *$ \\
\hline & [1.02] & {$[0.67]$} & {$[0.67]$} & {$[0.68]$} & {$[0.68]$} \\
\hline \multirow{2}{*}{ DUM85M5 } & $-1.4944 * *$ & $-2.1208 * * *$ & $-2.1208 * * *$ & $-2.0881 * * *$ & $-2.0881 * * *$ \\
\hline & [0.7] & {$[0.49]$} & [0.49] & [0.49] & [0.49] \\
\hline \multirow{2}{*}{ DUM05M2 } & $-0.8801 * *$ & $-1.4325 * * *$ & $-1.4325 * * *$ & $-1.067 * * *$ & $-1.067 * * *$ \\
\hline & {$[0.42]$} & {$[0.29]$} & [0.29] & {$[0.41]$} & {$[0.41]$} \\
\hline \multirow{2}{*}{ RECES } & $0.8357^{*}$ & $0.38888 *$ & $0.38888^{*}$ & 0.385 & 0.385 \\
\hline & {$[0.47]$} & {$[0.31]$} & {$[0.31]$} & {$[0.31]$} & {$[0.31]$} \\
\hline \multirow{2}{*}{ Constant } & & $1.5899 * * *$ & & & \\
\hline & & {$[0.32]$} & & & \\
\hline \multirow{2}{*}{ Trend } & & & & -0.0024 & \\
\hline & & & & {$[0.002]$} & \\
\hline Obs. & 662 & 662 & 662 & 662 & 662 \\
\hline Date & $\begin{array}{r}\text { 1960M11- } \\
2015 \mathrm{M} 12\end{array}$ & $\begin{array}{r}1960 \mathrm{M} 11- \\
2015 \mathrm{M} 12\end{array}$ & $\begin{array}{r}\text { 1960M11- } \\
2015 \mathrm{M} 12\end{array}$ & $\begin{array}{r}\text { 1960M11- } \\
2015 \mathrm{M} 12\end{array}$ & $\begin{array}{r}1960 \mathrm{M} 11- \\
2015 \mathrm{M} 12\end{array}$ \\
\hline
\end{tabular}

Note 1: *, **, and *** indicate significance at 1 percent, 5 percent, and 10 percent, respectively. 
Table 6B: Estimated Short-run Coefficients of Models Using the ARDL Approach (with GB10Y)

\begin{tabular}{|c|c|c|c|c|c|}
\hline Estimated & hort-run Co & ficients of $\mathbf{I}$ & Iodels using & the ARDL $A$ & pproach \\
\hline \multicolumn{6}{|c|}{ (with GB10Y) } \\
\hline & Model I & Model 2 & Model 3 & Model 4 & Model 5 \\
\hline \multicolumn{6}{|c|}{ Short-run Coefficients } \\
\hline \multirow{2}{*}{$\Delta(G B 10 Y(-1))$} & $0.3267^{* * * *}$ & $0.3362^{* * * *}$ & $0.3362^{* * * *}$ & $0.3343 * * *$ & $0.3343 * * *$ \\
\hline & {$[0.04]$} & {$[0.04]$} & {$[0.04]$} & {$[0.04]$} & {$[0.04]$} \\
\hline \multirow{2}{*}{$\Delta(G B 10 Y(-2))$} & $-0.2179 * * *$ & $-0.2051 * * *$ & $-0.2051 * * *$ & $-0.2051 * * *$ & $-0.2051 * * *$ \\
\hline & [0.04] & [0.04] & [0.04] & {$[0.04]$} & {$[0.04]$} \\
\hline \multirow{2}{*}{$\triangle(G B 10 Y(-3))$} & $0.12 * * *$ & $0.1317^{* * * *}$ & $0.1317 * * *$ & $0.13 * * *$ & $0.13 * * *$ \\
\hline & [0.04] & {$[0.04]$} & {$[0.04]$} & {$[0.04]$} & {$[0.04]$} \\
\hline \multirow{2}{*}{$\triangle(T B 3 N)$} & $0.3613^{* * *}$ & $0.3649^{* * *}$ & $0.3649 * * *$ & $0.3649 * * *$ & $0.3649 * * *$ \\
\hline & [0.02] & {$[0.02]$} & {$[0.02]$} & {$[0.02]$} & {$[0.02]$} \\
\hline \multirow{2}{*}{$\triangle(T B 3) Y(-1))$} & $-0.2396 * * *$ & $-0.1446^{* * * *}$ & $-0.1446 * * *$ & $-0.1371 * * *$ & $-0.1371 * * *$ \\
\hline & [0.04] & {$[0.03]$} & {$[0.03]$} & {$[0.03]$} & {$[0.03]$} \\
\hline \multirow{2}{*}{$\triangle(T B 3 M I(-2))$} & $0.2372^{* * * *}$ & $0.096^{* * * *}$ & $0.096^{* * * *}$ & $0.1018 * * *$ & $0.1018^{* * * *}$ \\
\hline & [0.04] & {$[0.03]$} & {$[0.03]$} & {$[0.03]$} & {$[0.03]$} \\
\hline \multirow{2}{*}{$\triangle(T B 3 M Y(-3))$} & $-0.1588 * * *$ & $-0.1401 * * *$ & $-0.1401 * * *$ & $-0.1347 * * *$ & $-0.1347^{* * * *}$ \\
\hline & {$[0.04]$} & {$[0.03]$} & {$[0.03]$} & {$[0.03]$} & {$[0.03]$} \\
\hline \multirow{2}{*}{$\triangle($ TB3MI(-4)) } & -0.0065 & 0.0219 & 0.0219 & 0.0258 & 0.0258 \\
\hline & {$[0.04]$} & {$[0.02]$} & {$[0.02]$} & {$[0.02]$} & {$[0.02]$} \\
\hline \multirow{2}{*}{$\triangle(T B 3 M Y(-5))$} & $0.1113^{* * *}$ & 0.0272 & 0.0272 & 0.0311 & 0.0311 \\
\hline & [0.04] & {$[0.02]$} & [0.02] & {$[0.02]$} & {$[0.02]$} \\
\hline \multirow{2}{*}{$\triangle(T B 3) \mathrm{M}(-6))$} & $-0.0967^{* * *}$ & $-0.0821 * * *$ & $-0.0821 * * *$ & $-0.079 * * *$ & $-0.079 * * *$ \\
\hline & {$[0.04]$} & {$[0.02]$} & {$[0.02]$} & {$[0.02]$} & {$[0.02]$} \\
\hline \multirow{2}{*}{$\triangle($ TB3MY(-7)) } & -0.0192 & 0.0114 & 0.0114 & 0.01367 & 0.01367 \\
\hline & {$[0.04]$} & {$[0.02]$} & {$[0.02]$} & {$[0.02]$} & {$[0.02]$} \\
\hline \multirow{2}{*}{$\triangle(T B 3 M Y(-8))$} & $0.1081 * * *$ & 0.0315 & 0.0315 & 0.0342 & 0.0342 \\
\hline & {$[0.04]$} & {$[0.02]$} & {$[0.02]$} & {$[0.02]$} & {$[0.02]$} \\
\hline \multirow{2}{*}{$\triangle(T B 3) Y(-9))$} & $-0.079 * * *$ & $-0.0738^{* * * *}$ & $-0.0738 * * *$ & $-0.0724 * * *$ & $-0.0724 * * *$ \\
\hline & [0.02] & {$[0.02]$} & [0.02] & {$[0.02]$} & {$[0.02]$} \\
\hline \multirow{2}{*}{$\Delta$ (INF) } & $0.0318^{* * * *}$ & $0.0355 * * *$ & $0.0355 * * *$ & $0.0442 * * *$ & $0.0442^{* * * *}$ \\
\hline & [0.01] & {$[0.01]$} & [0.01] & {$[0.01]$} & {$[0.01]$} \\
\hline \multirow{2}{*}{$\Delta(\mathbf{V})$} & $-0.0116^{* * *}$ & $-0.0149^{* * * *}$ & $-0.0149 * * *$ & $-0.011 \mathrm{~S}^{* *}$ & $-0.011 \mathrm{~S}^{* *}$ \\
\hline & [0.01] & [0.01] & [0.01] & {$[0.01]$} & {$[0.01]$} \\
\hline \multirow{2}{*}{$\Delta(1 \mathrm{P})$} & $0.0082^{* * * *}$ & $0.0049 *$ & $0.0049^{*}$ & $0.005 * *$ & $0.005 * *$ \\
\hline & {$[0.002]$} & {$[0.003]$} & [0.003] & {$[0.003]$} & {$[0.003]$} \\
\hline & $0.322^{* * * *}$ & $0.3683^{* * * *}$ & $0.3683^{* * * *}$ & $0.4083 * * *$ & $0.4083 * * *$ \\
\hline Dending & {$[0.13]$} & {$[0.13]$} & [0.13] & {$[0.13]$} & {$[0.13]$} \\
\hline DT TSTA & $-0.2843^{* * *}$ & -0.1919 & -0.1919 & -0.166 & -0.166 \\
\hline D. & [0.14] & [0.14] & [0.14] & {$[0.14]$} & {$[0.14]$} \\
\hline DUMR2UM & $0.1532^{* * *}$ & $0.1349 * *$ & $0.1349 * *$ & $0.155 * *$ & $0.155 * *$ \\
\hline DUND2M10 & {$[0.07]$} & {$[0.07]$} & {$[0.07]$} & {$[0.07]$} & {$[0.07]$} \\
\hline DIME & $-0.1039 * *$ & $-0.2221 * * *$ & $-0.2221 * * *$ & $-0.2196 * * *$ & $-0.2196^{* * * *}$ \\
\hline Do & [0.05] & {$[0.05]$} & [0.05] & {$[0.05]$} & {$[0.05]$} \\
\hline DUMO5M & $-0.0612^{* *}$ & $-0.1501 * * *$ & $-0.1501 * * *$ & $-0.1122^{* *}$ & $-0.1122^{* *}$ \\
\hline 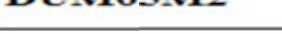 & [0.03] & {$[0.04]$} & {$[0.04]$} & {$[0.05]$} & {$[0.05]$} \\
\hline RECES & $0.0581 *$ & $0.0407 *$ & $0.0407 *$ & $0.0405^{*}$ & $0.0405^{*}$ \\
\hline NECES & [0.03] & {$[0.02]$} & [0.02] & {$[0.02]$} & {$[0.02]$} \\
\hline Constant & & & $0.1666 * * *$ & $0.203 * * *$ & $0.203 * * *$ \\
\hline & & & {$[0.04]$} & {$[0.05]$} & {$[0.05]$} \\
\hline Trend & & & & & -0.0003 \\
\hline Irend & & & & & {$[0.0002]$} \\
\hline ECT & $\begin{array}{r}-0.0695 * * * \\
{[0.01]}\end{array}$ & $\begin{array}{r}-0.1048^{* * * *} \\
{[0.01]}\end{array}$ & $\begin{array}{r}-0.1048^{* * * *} \\
{[0.01]}\end{array}$ & $\begin{array}{r}-0.1052 * * * * \\
{[0.01]}\end{array}$ & $\begin{array}{r}-0.1052^{* * *} \\
{[0.01]}\end{array}$ \\
\hline Obs. & 662 & 662 & 662 & 662 & 662 \\
\hline ate & $\begin{array}{r}1960 M 11- \\
2015 M 12\end{array}$ & $\begin{array}{r}1960 M 11- \\
2015 M 12\end{array}$ & $\begin{array}{r}\text { 1960M11- } \\
2015 M 12\end{array}$ & $\begin{array}{l}\text { 1960M11- } \\
2015 \mathrm{M1}\end{array}$ & $\begin{array}{r}1960 M 11- \\
2015 M 12\end{array}$ \\
\hline tructur & $410000)$ & $10000)$ & $+10000)$ & $410000)$ & $410000)$ \\
\hline
\end{tabular}

Note 1: *, **, and $* * *$ indicate significance at 1 percent, 5 percent, and 10 percent, respectively.

Note 2: " $\Delta X(-1)$ " represents one lag of the first difference variable; " $\Delta X(-i)$ " represents i lags of the first difference variable $X$. 


\subsubsection{Model Stability Check and Diagnosis}

Several diagnostic tests, shown in table $6 \mathrm{C}$, are performed to check the signs of various misspecifications, such as serial correlation, functional misspecifications, and heteroscedasticity.

Table 6C: Diagnostic Tests for Estimated ARDL Models

\begin{tabular}{|l|r|r|r|r|r|}
\hline \multicolumn{7}{|c|}{ Diagnos tic Tests For Estimated Models } \\
\hline \hline \multicolumn{7}{|c|}{ (with GB 10Y) } \\
\hline & Model 1 & Model 2 & \multicolumn{1}{c|}{ Model 3 } & Model 4 & Model 5 \\
\hline \multicolumn{7}{|c|}{ Dong-run Coefficients } \\
\hline Obs. & 662 & 662 & 662 & 662 & 662 \\
\hline Date & $1960 \mathrm{M} 11-$ & $1960 \mathrm{M} 11-$ & $1960 \mathrm{M} 11-$ & $1960 \mathrm{M} 11-$ & $1960 \mathrm{M} 11-$ \\
& $2015 \mathrm{M} 12$ & $2015 \mathrm{M} 12$ & $2015 \mathrm{M} 12$ & $2015 \mathrm{M} 12$ & $2015 \mathrm{M} 12$ \\
\hline Lag Structure & $(410000)$ & $(410000)$ & $(410000)$ & $(410000)$ & $(410000)$ \\
\hline AR(2) & 0.1770 & 0.3601 & 0.3601 & 0.4110 & 0.4110 \\
\hline AR(4) & 0.2602 & 0.5835 & 0.5835 & 0.6217 & 0.6217 \\
\hline RESET & 0.0124 & 0.6621 & 0.6621 & 0.7914 & 0.7914 \\
\hline HETER & 0.0319 & 0.0689 & 0.0689 & 0.0307 & 0.0307 \\
\hline
\end{tabular}

Note: AR(i) for i $=2,4$ denotes Breusch-Godfrey Lagrange multiplier test of serial correlation at lag i; RESET denotes regression specification error test; HETER denotes heteroscedasticity test.

First, the Breusch-Godfrey Lagrange multiplier test of autocorrelation in the residuals is implemented. The null hypothesis is that there is no autocorrelation. The results from the multiplier test show that for all models the null hypothesis cannot be rejected.

Second, besides model 1 (with p-value $=0.0124$ ), the RESET test shows that there is no functional form problem. However, three models (models 1, 4, and 5) fail the heteroscedasticity test at the 5 percent level. This may be suggestive of some measurement errors or nonlinear effects in the model specifications. ${ }^{18}$ Furthermore, when a linear trend is included in the model (model 4 and 5), the deterministic trend term is statistically insignificant. Thus, the diagnostic results point in favor of a model with intercepts but no trend (model 2 and 3 ).

\footnotetext{
${ }^{18}$ The p-values for the heteroscedasticity test are less than 0.05 for models 1,4 , and 5 . According to Shrestha and Chowdhury $(2005,25)$, "[s]ince the time series constituting the ARDL equation are potentially of mixed order of integration, i.e., I(0) and I(1), it is natural to detect heteroscedasticity."
} 
Finally, the cumulative sum of recursive residuals (CUSUM) and the CUSUM square (CUSUMSQ) tests, proposed by Brown, Durbin, and Evans (1975), are employed to investigate the stability of the estimated coefficients attached to the cointegrating vector and the error correction terms. In figures 20 and 21, the CUSUM and the CUSUMQ based on the first observations in model 2 are updated recursively and plotted against a breakpoint. These results show that the CUSUM and CUSUMSQ statistics are fairly confined within the 5 percent critical value bounds. This confirms that there is no evidence of statistically significant breaks. 
Figure 20: Plot of Cumulative Sum of Recursive Residuals (CUSUM) for Coefficient Stability for Model 2 (tables 6A and 6B)

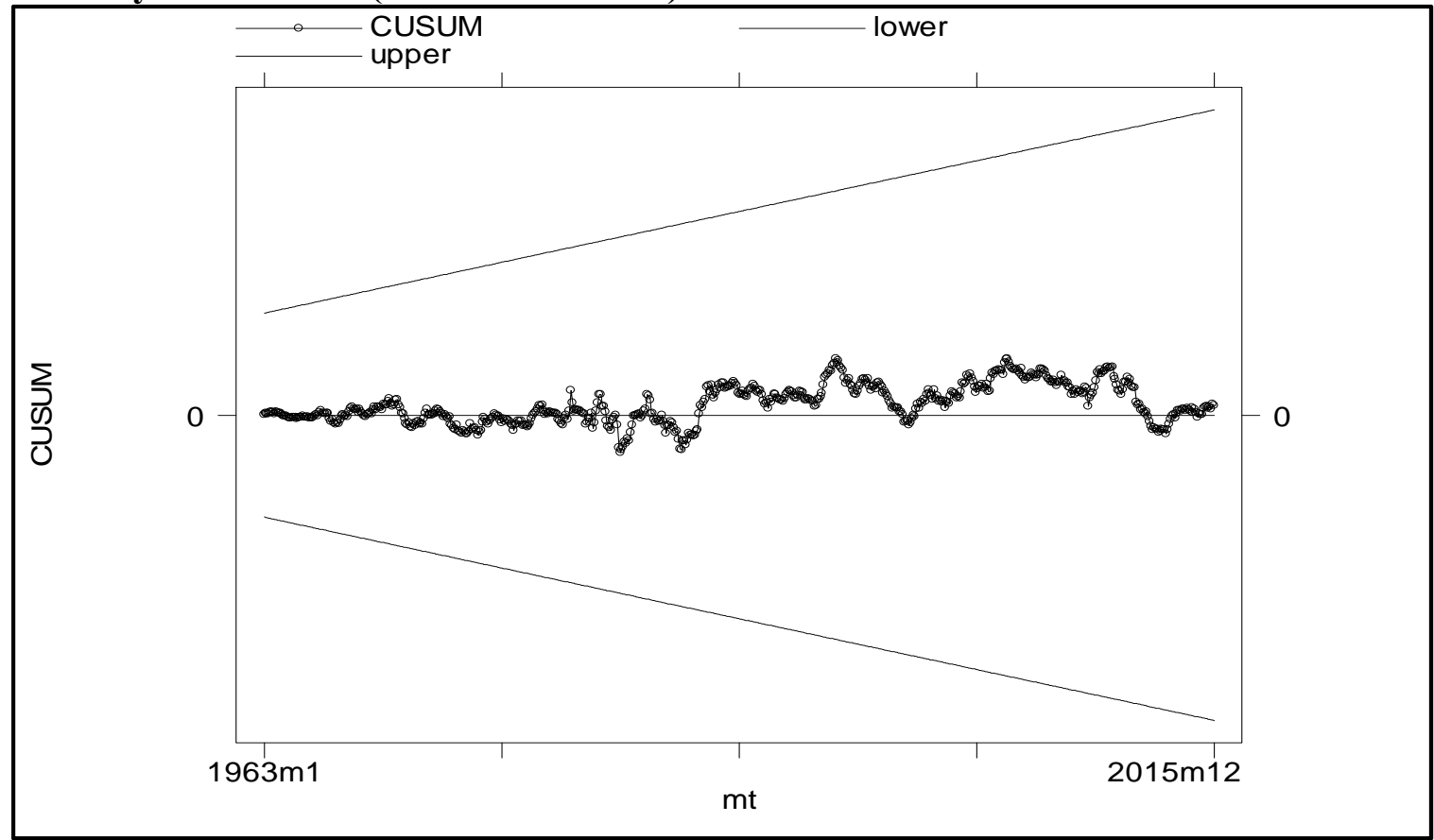

Figure 21: Plot of Cumulative Sum of Squares of Recursive Residuals (CUSUMQ) for Coefficient Stability for Model 2 (tables 6A and 6B)

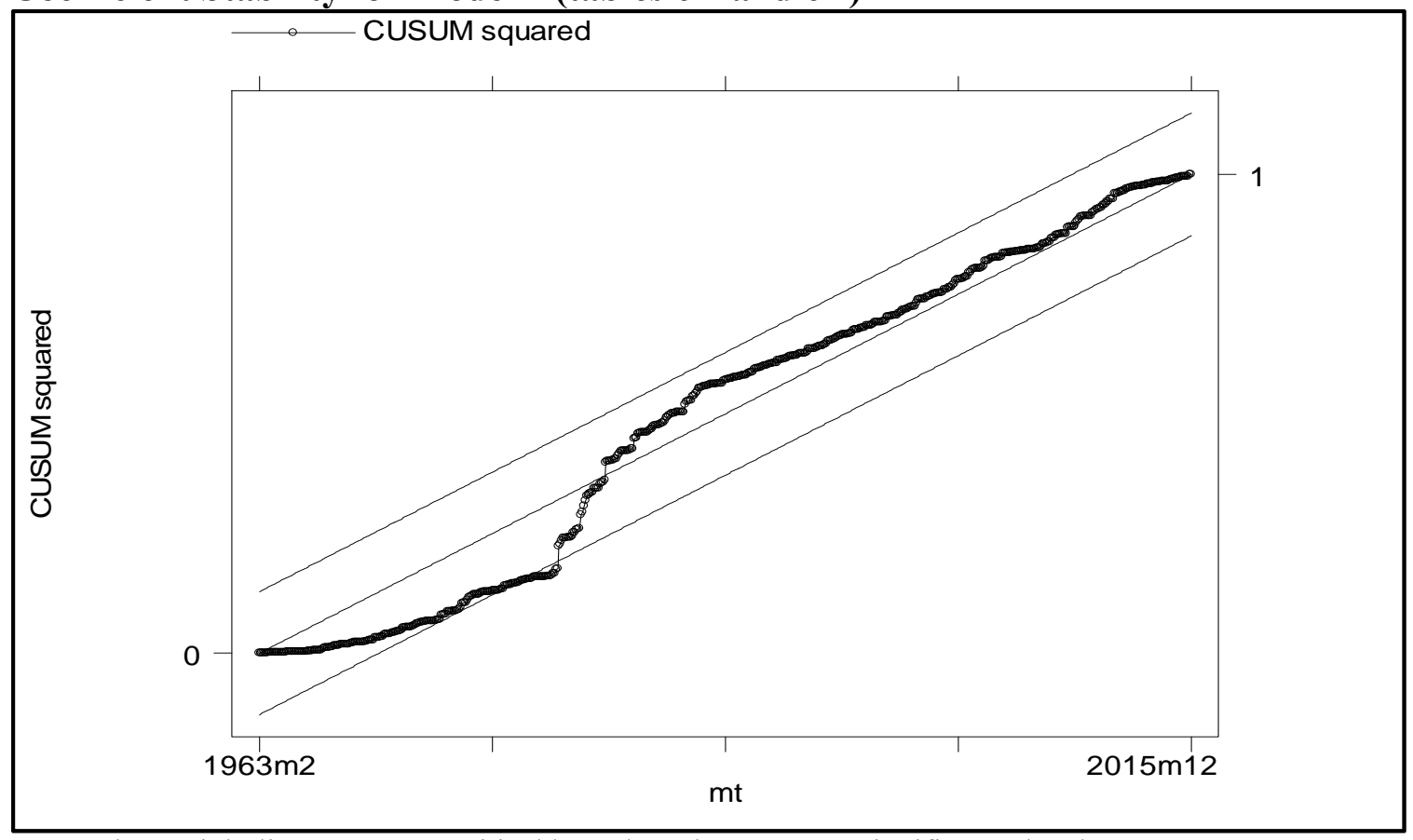

Note: The straight lines represent critical bounds at the 5 percent significance level. 


\subsection{Additional Empirical Analysis Supports the Key Findings}

The empirical analysis presented holds for Treasury securities of various tenors, different shortterm interest rates, and different measures of the rate of core inflation. Additional tables are provided in the appendix. These tables display the unit root tests for numerous variables and their first differences. These tables also give the estimated long-run and short-run coefficients of similar models using the ARDL approach for Treasury securities for 2-, 5, 7-, and 30-year tenors. These estimates show that the findings presented here are not contingent on the choice of the tenor of long-term Treasury securities, short-term interest rates on Treasury bills, and/or different measures of core inflation.

\section{CONCLUSION AND FURTHER RESEARCH}

\subsection{Key Findings}

This paper extends Akram and Li's (2017) recent study of long-term interest rates on US Treasury securities. It applies the bounds testing procedure to cointegration and error correction models within the ARDL framework to estimate a wider range of Keynesian models of longterm interest rates using monthly data. The findings of the paper support Keynes's (1930) hypothesis that short-term interest rates are the key determinants of long-term interest rates on government bonds and that the central bank's actions have a decisive influence on the Treasury yield curve. The empirical analysis shows that the other key drivers of long-term interest rates are the rate of core inflation and the pace of economic activity (as measured by the growth of industrial production). The empirical analysis undertaken here also finds that a higher (lower) ratio of the government net lending/borrowing balance (federal fiscal balance) leads to lower (higher) government bond yields. This means that an increase (decrease) in the fiscal surplus or a narrowing (widening) in the fiscal deficit ratio lowers (increases) government bond yields. While the government fiscal balance ratio has a statistically significant effect, the magnitude is quite small, and it pales in comparison to the effects of the short-term interest rate and the rate of inflation on the long-term interest rate. 
The findings of the paper are quite pertinent for current discussions and debates. They can inform a wide range of policy issues, such as the effects of monetary policy, quantitative easing, and low and negative policy rates on long-term interest rates. These results are relevant for policy debates on a range of current topics, including government debt sustainability, fiscal austerity, the eurozone crisis, the liquidity trap in advanced economies, the prospect of secular stagnation, and the mix of fiscal and monetary policies. It can also contribute to advances in contemporary macroeconomic theories related to the fiscal theory of price, modern money and chartalism, functional finance, fiscal policy, and central banking, providing a basis for further theoretical and empirical investigations of these questions.

\subsection{Areas of Further Research}

The findings of this paper are suggestive of topics for further research. First, different measures of federal government fiscal variables can be used. This paper has relied on the federal government fiscal balance ratio as the government fiscal variable. It would be fruitful to see if similar results hold when various government-debt-to-nominal-GDP ratios are used instead of government fiscal balance ratios. Three different ratios of federal debt to nominal GDP could be set as alternative measures of federal government fiscal conditions. These include: the ratio of total federal government debt; the ratio of federal government debt held by the public, including the Federal Reserve; and the ratio of the federal government debt held by the public, excluding the Federal Reserve. Second, it would be appropriate to determine if these results hold when different econometric and estimation techniques are applied. Third, impulse response functions could be provided to display the effects of various shocks to key underlying variables, the trajectory of adjustment paths, and the pace of the return to long-run equilibrium. Fourth, it would be propitious to establish the causality or the temporal precedence among variables to understand the complex macrodynamics of the yields of long-term Treasury securities. Fifth, the Keynesian models for government bond yields, such as the one presented in this paper, could be applied to other countries to examine whether similar empirical regularities are discernable in those countries' government bond markets. These issues shall be on the agenda for further research in the near future. 


\section{REFERENCES}

Akram, T. 2014. “The Economics of Japan's Stagnation.” Business Economics 49(3): 156-75.

Akram, T., and A. Das. 2014. "Understanding the Low Yields of the Long-Term Japanese Sovereign Debt." Journal of Economic Issues 48(2): 331-40.

- 2015. "A Keynesian Explanation of Indian Government Bond Yields." Journal of Post Keynesian Economics 38(4): 565-87.

_ 2017a. "The Long-Run Determinants of Indian Government Bond Yields." Levy Institute Working Paper No. 881. Annandale-on-Hudson, NY: Levy Economics Institute of Bard College.

_ 2017b. "The Dynamics of Government Bond Yields in the Eurozone." Levy Institute Working Paper No. 889. Annandale-on-Hudson, NY: Levy Economics Institute of Bard College.

Akram, T., and H. Li. 2016. "The Empirics of Long-Term US Interest Rates." Levy Institute Working Paper No. 863. Annandale-on-Hudson, NY: Levy Economics Institute of Bard College.

—. 2017. "What Keeps Long-Term U.S. Interest Rates So Low?" Economic Modelling 60: $380-90$.

Baldacci, E., and M. Kumar. 2010. "Fiscal Deficits, Public Debt, and Sovereign Bond Yields." IMF Working Paper No. 10/184. Washington, DC: International Monetary Fund.

Bindseil, U. 2004. Monetary Policy Implementation: Theory, Past, and Present. Oxford, UK and New York: Oxford University Press.

Brown, R. L., J. Durbin, and J. M. Evans. 1975. "Techniques for Testing the Constancy of Regression Relationships Over Time." Journal of the Royal Statistical Society, Series B, 37(2): 149-92.

Davidson, P. 2011. Post Keynesian Macroeconomic Theory, second edition. Cheltenham, UK and Northampton, MA: Edward Elgar.

-2015. Post Keynesian Theory and Policy: A Realistic Analysis of the Market Oriented Capitalist Economy. Cheltenham, UK and Northampton, MA: Edward Elgar. 
Dickey, D. A., and W. A. Fuller. 1979. "Distribution of the Estimators for Autoregressive Time Series with a Unit Root." Journal of the American Statistical Association 74(366): 42731.

_ 1981. "Likelihood Ratio Statistics for Autoregressive Time Series with a Unit Root." Econometrica 49(4): 1057-72.

Engle, R. F., and C. W. J. Granger. 1987. "Co-Integration and Error Correction: Representation, Estimation, and Testing.” Econometrica 55(2): 251-76.

Fullwiler, S. T. 2016. "The Debt Ratio and Sustainable Macroeconomic Policy.” World Economic Review 7: 12-42.

Gregory, A. W., and B. E. Hansen. 1996. "Residual-Based Tests for Cointegration in Models with Regime Shifts.” Journal of Econometrics 70(1): 99-126.

Gregory, A. W., and J. B. E. Nason. 1996. "Testing for Structural Breaks in Cointegrated Relationships.” Journal of Econometrics 71(1-2): 321-41.

Gruber, J. W., and S. B. Kamin. 2012. "Fiscal Positions and Government Bond Yields in OECD Countries." Journal of Money, Credit, and Banking 44(8): 1563-87.

Hassler, U., and J. Wolters. 2006. "Autoregressive Distributed Lag Models and Cointegration.” Allgemeines Statistisches Archiv 90(1): 59-74.

Johansen, S. 1988. "Statistical Analysis of Cointegration Vectors." Journal of Economic Dynamics and Control 12(2): 231-54.

- 1991. "Estimation and Hypothesis Testing of Cointegration Vectors in Gaussian Vector Autoregressive Models." Econometrica 59(6): 1551-80.

_. 1995. Likelihood-Based Inference in Cointegrated Vector Autoregressive Models. Oxford, UK: Clarendon Press.

Johansen, S., and K. Juselius. 1990. "Maximum Likelihood Estimation and Inference on Cointegration with Applications to the Demand for Money." Oxford Bulletin of Economics and Statistics 52(2): 169-210.

Keynes, J. M., 1930. A Treatise on Money, Vol. II: The Applied Theory of Money. London: Macmillan. 
— 2007 [1936]. The General Theory of Employment, Interest, and Money. New York: Palgrave Macmillan.

Kregel, J. 2011. "Was Keynes' Monetary Policy, À Outrance in the Treatise, A Forerunner of ZIRP and QE? Did He Change his Mind in the General Theory?" Levy Institute, Policy Note No. 2011/4. Annandale-on-Hudson, NY: Levy Economics Institute of Bard College.

Kripfganz, S., and D. C. Schneider. 2016. "ardl: Stata module to estimate autoregressive distributed lag models." Paper presented at the Stata Conference, Chicago, IL, July 29.

Lam, R. W., and K. Tokuoka. 2013. "Assessing the Risks to the Japanese Government Bond (JGB) Market." Journal of International Commerce, Economics and Policy 4(1): 1350002-1-1350002-15.

Lavoie, M. 2009 [2007]. Introduction to Post-Keynesian Economics, paperback edition. Hampshire, UK: Palgrave Macmillan.

- 2014. Post-Keynesian Economics: New Foundations. Cheltenham, UK and Northampton, MA: Edward Elgar.

Macrobond, various years. Macrobond subscription services (accessed May 15, 2017).

MacKinnon, J. G. 1991. "Critical values for Cointegration Tests.” In R. F. Engle and C. W. J. Granger (ed.), Long-Run Economic Relationships: Readings in Cointegration. Oxford, UK: Oxford University Press.

Paccagnini, A. 2016. "The Macroeconomic Determinants of the US Term Structure during the Great Moderation.” Economic Modelling 52(A): 216-25.

Papadamou, S. 2013. "Market Anticipation of Monetary Policy Actions and Interest Rate Transmission to US Treasury Market Rates.” Economic Modelling 33: 545-51.

Pesaran, M. H., and Y. Shin. 1999. "An Autoregressive Distributed Lag Modelling Approach to Cointegration Analysis." In S. Strom (ed.), Econometrics and Economic Theory in the 20th Century: The Ragnar Frisch Centennial Symposium. Cambridge, UK: Cambridge University Press.

Pesaran, M. H., Y. Shin, and R. J. Smith. 1999. "Bounds Testing Approaches to the Analysis of Long Run Relationships." Edinburgh School of Economics, Discussion Paper Series No. 46. Edinburgh: Edinburgh School of Economics. Available at: http://www.econ.ed.ac.uk/papers/id46_esedps.pdf (accessed July 21, 2017). 
- 2001. "Bounds Testing Approaches to the Analysis of Level Relationships." Journal of Applied Econometrics 16(3): 289-326.

Phillips, P. C. B., and P. Perron. 1988. "Testing for a Unit Root in Time Series Regression." Biometrika 75(2): 335-46.

Poghosyan, T. 2014. "Long-Run and Short-Run Determinants of Sovereign Bond Yields in Advanced Economies.” Economic Systems 38(1): 100-14.

Reinhart, C. M., and K. S. Rogoff. 2009. This Time is Different: Eight Centuries of Financial Folly. Princeton, NJ: Princeton University Press.

Riefler, W. W. 1930. Money Rates and Money Markets in the United States. New York and London: Harper \& Brothers.

Shehata, E. A. E. 2011. "CHOWREG: Stata Module to Estimate Structural Change Regressions and Compute Chow Test." Giza: Agricultural Research Center, Agricultural Economics Research Institute. Available at: http://fmwww.bc.edu/repec/bocode/c/chowreg.ado

Shrestha, M. B., and K. Chowdhury. 2005. "ARDL Modelling Approach to Testing the Financial Liberalisation Hypothesis." Working Paper 05-15. Wollongong, New South Wales: Department of Economics, University of Wollongong. Available at: http://ro.uow.edu.au/cgi/viewcontent.cgi?article=1122\&context=commwkpapers

Sims, C. 2013. “Paper Money.” American Economic Review 103(2): 563-84.

Tcherneva, P. R. 2011. "Bernanke's Paradox: Can He Reconcile His Position on the Federal Budget with His Recent Charge to Prevent Deflation?" Journal of Post Keynesian Economics 33(3): 411-34.

Tokuoka, K. 2012. “Intergenerational Implications of Fiscal Consolidation in Japan.” IMF Working Paper No. 12/197. Washington, DC: International Monetary Fund. Available at: http://www.imf.org/external/pubs/ft/wp/2012/wp12197.pdf (accessed May 15, 2017).

Woodford, M. 2001. "Fiscal Requirements for Price Stability." Journal of Money, Credit and Banking 33(3): 669-728.

Wray, L. R. 2003 [1998]. Understanding Modern Money: The Key to Full Employment and Price Stability, paperback edition. Cheltenham, UK and Northampton, MA: Edward Elgar. 
— 2012. Modern Money Theory: A Primer on Macroeconomics for Sovereign Monetary Systems. New York: Palgrave Macmillan. 


\section{APPENDIX: ADDITIONAL TABLES}

Table A1: Unit Root Tests (Level)

\begin{tabular}{|c|c|c|c|c|c|}
\hline \multicolumn{6}{|c|}{$\begin{array}{c}\text { Appendix Table Al } \\
\text { Unit-root Tests (Level) }\end{array}$} \\
\hline Variable & & Tests & Statistic & P-value & Obs. \\
\hline \multirow{6}{*}{ TB3M } & \multirow{2}{*}{ Trend } & ADF & -2.071 & 0.562 & 681 \\
\hline & & PP & -2.189 & 0.496 & 681 \\
\hline & \multirow{2}{*}{ No trend } & ADF & -1.527 & 0.520 & 681 \\
\hline & & PP & -1.679 & 0.442 & 681 \\
\hline & \multirow{2}{*}{$\begin{array}{l}\text { No trend, No } \\
\text { constant }\end{array}$} & ADF & -1.145 & 0.423 & 681 \\
\hline & & PP & -1.151 & 0.343 & 681 \\
\hline \multirow{6}{*}{ TВ6M } & \multirow{2}{*}{ Trend } & ADF & -1.970 & $0.61 \mathrm{~s}$ & 681 \\
\hline & & PP & -3.221 & 0.080 & 681 \\
\hline & \multirow{2}{*}{ No trend } & $A D F$ & -1.409 & 0.578 & $6 S 1$ \\
\hline & & PP & -1.076 & 0.724 & 681 \\
\hline & \multirow{2}{*}{$\begin{array}{l}\text { No trend, No } \\
\text { constant }\end{array}$} & ADF & -1.103 & 0.412 & 681 \\
\hline & & PP & -1.102 & 0.672 & 681 \\
\hline \multirow{6}{*}{ GB2Y } & \multirow{2}{*}{ Trend } & ADF & $-2.94 \mathrm{~S}$ & 0.147 & 484 \\
\hline & & PP & -1.920 & 0.644 & 484 \\
\hline & \multirow{2}{*}{ No trend } & $A D F$ & -0.923 & 0.780 & 484 \\
\hline & & PP & -1.328 & 0.617 & $4 S 4$ \\
\hline & No trend, No & ADF & -1.082 & 0.634 & 484 \\
\hline & constant & PP & -0.678 & 0.522 & 484 \\
\hline & & ADF & -1.621 & 0.784 & 681 \\
\hline & Trend & PP & -1.920 & 0.644 & 681 \\
\hline & & ADF & -1.002 & 0.753 & 681 \\
\hline GBSY & No trend & PP & $-1.32 \mathrm{~S}$ & 0.617 & 681 \\
\hline & No trend, No & ADF & -0.839 & 0.538 & 681 \\
\hline & constant & PP & $-0.67 \mathrm{~S}$ & 0.522 & 681 \\
\hline & & ADF & -2.254 & 0.460 & 567 \\
\hline & Trend & PP & -3.482 & 0.041 & 567 \\
\hline GRTY & & ADF & -0.759 & 0.831 & 567 \\
\hline GBS & No trend & PP & -0.920 & 0.781 & 567 \\
\hline & No trend, No & ADF & -0.938 & 0.652 & 567 \\
\hline & constant & PP & -0.926 & 0.662 & 567 \\
\hline & & ADF & -1.464 & 0.841 & 681 \\
\hline & Irend & PP & -3.226 & 0.079 & 681 \\
\hline GR10Y & No trend & ADF & -0.872 & 0.797 & 681 \\
\hline GBOXY & Not trenda & PP & -1.077 & 0.724 & 681 \\
\hline & No trend, No & ADF & -0.725 & 0.652 & $6 S_{1}$ \\
\hline & constant & PP & -1.100 & 0.232 & 681 \\
\hline & & ADF & -3.282 & 0.069 & 476 \\
\hline & Irend & PP & -1.679 & 0.760 & 476 \\
\hline GB30Y & No trend & ADF & -0.527 & 0.857 & 476 \\
\hline GBSOX & Noo dend & PP & -1.299 & 0.630 & 476 \\
\hline & No trend, No & ADF & -1.003 & 0.682 & 476 \\
\hline & constant & PP & -0.721 & 0.232 & 476 \\
\hline & Trend & ADF & -5.987 & 0.0000 & 681 \\
\hline & IFena & PP & -5.488 & 0.0000 & 681 \\
\hline IP & No trand & ADF & -5.425 & 0.0000 & 681 \\
\hline W & No trend & PP & -5.200 & 0.0000 & 681 \\
\hline & No trend, No & ADF & -4.095 & 0.0000 & 681 \\
\hline & constant & PP & -4.589 & 0.0000 & 681 \\
\hline & Trend & ADF & -1.709 & 0.747 & 681 \\
\hline & Trend & PP & -2.567 & 0.295 & 681 \\
\hline NNF(CPD & No trend & ADF & -1.329 & 0.616 & 681 \\
\hline RVI (C) & No trend & PP & -2.256 & 0.187 & $6 S_{1}$ \\
\hline & No trend, No & ADF & -0.731 & 0.452 & 681 \\
\hline & constant & PP & -1.337 & 0.212 & 681 \\
\hline & Trend & ADF & -1.506 & 0.827 & 680 \\
\hline & Hrend & PP & -2.782 & 0.204 & 680 \\
\hline NNF $O P C F$ & No trend & ADF & -0.932 & 0.777 & 680 \\
\hline LNF(PCE) & No trend & PP & -2.541 & 0.106 & 680 \\
\hline & No trend, No & ADF & -0.578 & 0.554 & 680 \\
\hline & constant & PP & -1.473 & 0.254 & 680 \\
\hline & Trend & ADF & -1.423 & 0.854 & 671 \\
\hline & Hend & PP & -1.409 & 0.578 & 671 \\
\hline $\mathbf{v}$ & No trend & ADF & -1.456 & 0.555 & 671 \\
\hline & No trend & PP & 0.808 & 0.992 & 671 \\
\hline & No trend, No & ADF & -0.777 & 0.664 & 671 \\
\hline & constant & PP & -0.777 & 0.341 & 671 \\
\hline
\end{tabular}


Table A2: Unit Root Tests (First Difference)

\begin{tabular}{|c|c|c|c|c|c|}
\hline \multicolumn{6}{|c|}{ Appendix Table A2 } \\
\hline \multicolumn{6}{|c|}{ Unit root Tests (First-difference) } \\
\hline Variable & & Tests & Statistic & P-value & Obs. \\
\hline \multirow{6}{*}{$\triangle \mathbf{T B} \mathbf{3 M}$} & \multirow{2}{*}{ Trend } & ADF & -18.431 & 0.000 & 680 \\
\hline & & PP & -2.189 & 0.000 & 650 \\
\hline & \multirow{2}{*}{ No trend } & ADF & -18.431 & 0.000 & 680 \\
\hline & & PP & -1.679 & 0.000 & 650 \\
\hline & \multirow{2}{*}{$\begin{array}{l}\text { No trend, No } \\
\text { constant }\end{array}$} & ADF & -18.443 & 0.000 & 680 \\
\hline & & PP & -1.151 & 0.000 & 680 \\
\hline \multirow{6}{*}{$\triangle T$ TBWM } & \multirow{2}{*}{ Trend } & ADF & -18.094 & 0.000 & 680 \\
\hline & & PP & -3.221 & 0.000 & 680 \\
\hline & \multirow{2}{*}{ No trend } & ADF & $-1 \mathrm{~S} .094$ & 0.000 & 650 \\
\hline & & PP & -1.076 & 0.000 & 680 \\
\hline & \multirow{2}{*}{$\begin{array}{l}\text { No trend, No } \\
\text { constant }\end{array}$} & ADF & -18.105 & 0.000 & 680 \\
\hline & & PP & -1.102 & 0.000 & 680 \\
\hline \multirow{6}{*}{$\triangle \mathbf{G B} 2 \mathbf{Y}$} & \multirow{2}{*}{ Trend } & ADF & -15.114 & 0.000 & 483 \\
\hline & & PP & -1.92 & 0.000 & 483 \\
\hline & & ADF & -15.12 & 0.000 & 483 \\
\hline & No trend & PP & $-1.32 \mathrm{~S}$ & 0.000 & 483 \\
\hline & No trend, No & ADF & -15.126 & 0.000 & 483 \\
\hline & constant & PP & -0.678 & 0.000 & 483 \\
\hline & Trend & ADF & -18.327 & 0.000 & 680 \\
\hline & Irend & PP & -1.92 & 0.000 & 680 \\
\hline & & ADF & -18.312 & 0.000 & 650 \\
\hline$\triangle G B S Y$ & No trend & PP & -1.328 & 0.000 & 680 \\
\hline & No trend, No & ADF & $-1 \mathrm{~S} .322$ & 0.000 & 680 \\
\hline & constant & PP & -0.678 & 0.000 & 680 \\
\hline & Trend & $A D F$ & -17.036 & 0.000 & 566 \\
\hline & Trend & PP & -3.482 & 0.000 & 566 \\
\hline$M P=\mathbf{Y}$ & Tintrend & ADF & -17.028 & 0.000 & 566 \\
\hline$\Delta G B S$ & No trend & PP & -0.92 & 0.000 & 566 \\
\hline & No trend, No & ADF & -17.033 & 0.000 & 566 \\
\hline & constant & PP & -0.926 & 0.000 & 566 \\
\hline & Trend & ADF & -19.124 & 0.000 & 680 \\
\hline & Trend & PP & -3.226 & 0.000 & 680 \\
\hline 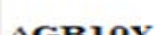 & To trend & ADF & -19.09 & 0.000 & 680 \\
\hline$\triangle G B 10 Y$ & No trend & PP & -1.077 & 0.000 & 680 \\
\hline & No trend, No & ADF & -19.101 & 0.000 & 680 \\
\hline & constant & PP & -1.1 & 0.000 & 650 \\
\hline & & ADF & -15.718 & 0.000 & 475 \\
\hline & Trend & PP & -1.679 & 0.000 & 475 \\
\hline AGP30Y & No trend & ADF & -15.711 & 0.000 & 475 \\
\hline$\triangle G B 30 Y$ & No trend & PP & -1.299 & 0.000 & 475 \\
\hline & No trend, No & ADF & -15.709 & 0.000 & 475 \\
\hline & constant & PP & -0.721 & 0.000 & 475 \\
\hline & Trend & ADF & -18.399 & 0.000 & 680 \\
\hline & Frend & PP & $-3.4 \mathrm{SB}$ & 0.000 & 680 \\
\hline $\mathbf{P P}$ & & ADF & -18.414 & 0.000 & 680 \\
\hline$\Delta \mathbf{I P}$ & No trend & PP & -0.919 & 0.000 & 680 \\
\hline & No trena, wo & $A D F$ & -18.427 & 0.000 & 680 \\
\hline & & PP & -0.925 & 0.000 & 680 \\
\hline & Trand & ADF & -19.649 & 0.000 & 680 \\
\hline & Irend & PP & -2.567 & 0.000 & 650 \\
\hline $\mathbf{A P T}_{\mathbf{P}}$ & Notrend & ADF & -19.651 & 0.000 & 680 \\
\hline$\Delta C F$ & Noo aria & PP & -2.256 & 0.000 & 680 \\
\hline & No trend, No & ADF & -19.665 & 0.000 & 680 \\
\hline & constant & PP & -1.337 & 0.000 & 680 \\
\hline & Trend & ADF & -17.968 & 0.000 & 679 \\
\hline & Hrend & PP & -2.782 & 0.000 & 679 \\
\hline$\sim \mathbf{P} \sim \mathbf{F}$ & Totrend & ADF & -17.958 & 0.000 & 679 \\
\hline$\triangle P C$ & Noo trema & PP & -2.541 & 0.000 & 679 \\
\hline & No trend, No & ADF & -17.971 & 0.000 & 679 \\
\hline & constant & PP & -1.473 & 0.000 & 679 \\
\hline & Trend & $A D F$ & -21.605 & 0.000 & 670 \\
\hline & Trend & PP & -0.63 & 0.000 & 670 \\
\hline 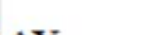 & Thtond & ADF & -21.535 & 0.000 & 670 \\
\hline$\Delta \mathbf{v}$ & No trend & PP & 0.808 & 0.000 & 670 \\
\hline & No trend, No & ADF & -21.48 & 0.000 & 670 \\
\hline & constant & PP & 1.231 & 0.000 & 670 \\
\hline
\end{tabular}


Table A3: Estimated Long-run and Short-run Coefficients Using the ARDL Approach (with GB2Y)

\begin{tabular}{|c|c|c|c|c|c|c|c|c|c|c|}
\hline \multicolumn{11}{|c|}{ Appendix Table A6 } \\
\hline \multicolumn{11}{|c|}{ Estimated Long-run and Short-run Coefficients using the ARDL Approach } \\
\hline \multicolumn{11}{|c|}{ (with GB2Y) } \\
\hline & \multicolumn{2}{|c|}{ Model 1} & \multicolumn{2}{|c|}{ Model 2} & \multicolumn{2}{|c|}{ Model 3} & \multicolumn{2}{|c|}{ Model 4} & \multicolumn{2}{|c|}{ Model 5} \\
\hline & Coefficient & Prob. & Coefficient & Prob. & Coefficient & Prob. & Coefficient & Prob. & Coefficient & Prob. \\
\hline \multicolumn{11}{|c|}{ Long-run Coefficients } \\
\hline R_ST & 0.8347 & 0.0000 & 0.8651 & 0.0000 & 0.8651 & 0.0000 & 0.7179 & 0.0000 & 0.7179 & 0.0000 \\
\hline INF & 0.2105 & 0.0164 & 0.1120 & 0.4303 & 0.1120 & 0.4303 & 0.0037 & 0.9579 & 0.0037 & 0.9579 \\
\hline $\mathrm{V}$ & -0.0226 & 0.6185 & -0.0305 & $0.489 \mathrm{~s}$ & -0.0305 & 0.4898 & 0.0575 & 0.0603 & 0.0575 & 0.0603 \\
\hline IP & 0.0665 & 0.0209 & 0.0544 & 0.0777 & 0.0544 & 0.0777 & .0 .0054 & 0.7385 & -0.0054 & 0.7385 \\
\hline DUM80M12 & 1.9121 & 0.2318 & 1.9971 & 0.1967 & 1.9971 & 0.1967 & 1.7657 & 0.0320 & 1.7657 & 0.0320 \\
\hline DUM81M4 & 0.1535 & 0.9163 & -0.0539 & 0.9704 & -0.0539 & 0.9704 & 0.9828 & 0.1823 & 0.9828 & 0.1823 \\
\hline DUM82M10 & -0.2522 & 0.7370 & -0.5694 & 0.4927 & -0.5694 & 0.4927 & .0 .2952 & 0.4847 & -0.2952 & 0.4847 \\
\hline DUM85M5 & -1.1198 & 0.0154 & -1.1549 & 0.0098 & -1.1549 & 0.0098 & -1.0826 & 0.0000 & -1.0826 & 0.0000 \\
\hline DUM05M2 & -0.7035 & 0.0091 & -0.7716 & 0.0046 & -0.7716 & 0.0046 & 0.4442 & 0.0564 & 0.4442 & 0.0564 \\
\hline RECES & 0.2067 & 0.6003 & 0.1688 & 0.6574 & 0.1688 & 0.6574 & 0.0219 & 0.9080 & 0.0219 & 0.9080 \\
\hline Constant & & & 0.6684 & 0.4073 & & & & & & \\
\hline Trend & & & & & & & .0 .0098 & 0.0083 & & \\
\hline \multicolumn{11}{|c|}{ Short-run Coefficients } \\
\hline$\Delta($ GB2Y(-1)) & 0.3807 & 0.0000 & 0.3819 & 0.0000 & 0.3819 & 0.0000 & 0.4431 & 0.0000 & 0.4431 & 0.0000 \\
\hline$\Delta($ GB2Y $(-2))$ & -0.2959 & 0.0000 & -0.2938 & 0.0000 & -0.2938 & 0.0000 & -0.1917 & 0.0008 & -0.1917 & 0.0008 \\
\hline$\Delta($ GB2Y $(-3))$ & 0.1400 & 0.0047 & 0.1429 & 0.0040 & 0.1429 & 0.0040 & 0.2205 & 0.0001 & 0.2205 & 0.0001 \\
\hline$\Delta($ GB2Y $(-4))$ & -0.0745 & 0.1175 & -0.0711 & 0.1369 & -0.0711 & 0.1369 & .0 .0019 & 0.9708 & -0.0019 & 0.9708 \\
\hline$\Delta($ GB2Y $(-5))$ & & & & & & & 0.0024 & 0.9653 & 0.0024 & 0.9653 \\
\hline$\Delta($ GB2Y $(-6))$ & & & & & & & 0.1190 & 0.0280 & 0.1190 & 0.0280 \\
\hline$\Delta($ GB2Y $(-7))$ & & & & & & & 0.0392 & 0.4688 & 0.0392 & 0.4688 \\
\hline$\Delta($ GB2Y $(-8))$ & & & & & & & 0.0772 & 0.1509 & 0.0772 & 0.1509 \\
\hline$\Delta($ GB2Y(-9)) & & & & & & & -0.0211 & 0.6674 & -0.0211 & 0.6674 \\
\hline$\Delta($ GB2Y $(-10))$ & & & & & & & 0.1045 & 0.0284 & 0.1045 & 0.0284 \\
\hline$\Delta($ GB2Y $(-11))$ & & & & & & & 0.0895 & 0.0036 & 0.0895 & 0.0036 \\
\hline$\Delta(\mathrm{TB} 3 \mathrm{M})$ & 0.7629 & 0.0000 & 0.7641 & 0.0000 & 0.7641 & 0.0000 & 0.7560 & 0.0000 & 0.7560 & 0.0000 \\
\hline$\Delta(\mathrm{TB} 3 \mathrm{M}(-1))$ & $-0.61 \$ 2$ & 0.0000 & -0.6181 & 0.0000 & -0.6181 & 0.0000 & -0.5593 & 0.0000 & -0.5593 & 0.0000 \\
\hline$\Delta($ TB3M $(-2))$ & 0.4998 & 0.0000 & 0.5006 & 0.0000 & 0.5006 & 0.0000 & 0.4463 & 0.0000 & 0.4463 & 0.0000 \\
\hline$\Delta(\mathrm{TB} 3 \mathrm{M}(-3))$ & -0.3257 & 0.0000 & -0.3242 & 0.0000 & -0.3242 & 0.0000 & .0 .3316 & 0.0000 & -0.3316 & 0.0000 \\
\hline$\Delta($ IB3M $(-4))$ & 0.0860 & 0.1770 & 0.0827 & 0.1955 & 0.0827 & 0.1955 & 0.0655 & $0.418 \mathrm{~s}$ & 0.0655 & 0.4188 \\
\hline$\Delta($ TB3M(-5)) & 0.0799 & 0.1079 & 0.0797 & 0.1087 & 0.0797 & 0.1087 & 0.1673 & 0.0432 & 0.1673 & 0.0432 \\
\hline$\Delta($ TB3M(-6)) & -0.1487 & 0.0028 & -0.1493 & 0.0027 & -0.1493 & 0.0027 & -0.2175 & 0.0093 & -0.2175 & 0.0093 \\
\hline$\Delta($ IB3M(-7)) & 0.0685 & 0.1591 & 0.0673 & 0.1676 & 0.0673 & 0.1676 & 0.0921 & 0.2667 & 0.0921 & 0.2667 \\
\hline$\Delta($ IB3M(-8)) & 0.1184 & 0.0095 & 0.1160 & 0.0109 & 0.1160 & 0.0109 & 0.0298 & 0.7106 & 0.0298 & 0.7106 \\
\hline$\Delta($ TB3M(-9)) & -0.1037 & 0.0003 & -0.1024 & 0.0003 & -0.1024 & 0.0003 & 0.0510 & 0.4907 & 0.0510 & 0.4907 \\
\hline$\Delta($ TB3M(-10)) & & & & & & & -0.1101 & 0.0173 & -0.1101 & 0.0173 \\
\hline$\Delta$ (CPI) & -0.0050 & 0.9252 & -0.0097 & 0.8584 & -0.0097 & 0.8584 & -0.0151 & 0.7883 & -0.0151 & 0.7883 \\
\hline$\Delta($ CPI $(-1))$ & 0.0290 & 0.7045 & 0.0289 & 0.7061 & 0.0289 & 0.7061 & .0 .0204 & 0.7939 & -0.0204 & 0.7939 \\
\hline$\Delta(\mathrm{CPI}(-2))$ & 0.0980 & 0.2004 & 0.0980 & 0.2005 & 0.0980 & 0.2005 & 0.0927 & 0.2405 & 0.0927 & 0.2405 \\
\hline$\Delta($ CPI $(-3))$ & 0.0455 & 0.5543 & 0.0484 & 0.3306 & 0.0484 & 0.5306 & 0.0298 & 0.7015 & 0.0298 & 0.7015 \\
\hline$\Delta($ CPI $(-4))$ & -0.0856 & 0.2655 & -0.0847 & 0.2709 & -0.0847 & 0.2709 & -0.0639 & 0.4088 & -0.0639 & 0.4088 \\
\hline$\Delta($ CPI $(-5))$ & -0.0845 & 0.2653 & -0.0854 & 0.2607 & -0.0854 & 0.2607 & .0 .1062 & 0.1673 & -0.1062 & 0.1673 \\
\hline$\Delta($ CPI(-6)) & 0.2387 & 0.0017 & 0.2383 & 0.0018 & 0.2383 & 0.0018 & 0.2156 & 0.0053 & 0.2156 & 0.0053 \\
\hline$\Delta($ CPI $(-7))$ & -0.1252 & 0.0114 & -0.1199 & 0.0163 & -0.1199 & 0.0163 & -0.0422 & 0.5887 & -0.0422 & 0.5887 \\
\hline$\Delta($ CPI $(-8))$ & & & & & & & 0.0271 & 0.7256 & 0.0271 & 0.7256 \\
\hline$\Delta($ CPI $(-9))$ & & & & & & & .0 .1614 & 0.0350 & -0.1614 & 0.0350 \\
\hline$\Delta($ CPI $(-10))$ & & & & & & & 0.1143 & 0.0257 & 0.1143 & 0.0257 \\
\hline$\Delta(\mathrm{V})$ & -0.0616 & 0.1165 & -0.0593 & 0.1316 & -0.0593 & 0.1316 & .0 .0594 & 0.1240 & -0.0594 & 0.1240 \\
\hline$\Delta$ (IP) & 0.0070 & 0.5468 & 0.0058 & 0.6164 & $0.005 \mathrm{~s}$ & 0.6164 & 0.0076 & 0.5259 & 0.0076 & 0.5259 \\
\hline$\Delta(\mathbf{I P}(-1))$ & 0.0218 & 0.0543 & 0.0221 & 0.0518 & 0.0221 & 0.0518 & 0.0316 & 0.0062 & 0.0316 & 0.0062 \\
\hline DUM80M12 & 0.2144 & 0.1889 & 0.2333 & 0.1573 & 0.2333 & 0.1573 & 0.4143 & $0.018 \mathrm{~s}$ & 0.4143 & 0.0188 \\
\hline DUM81M4 & 0.0174 & 0.9168 & -0.0063 & 0.9704 & -0.0063 & 0.9704 & 0.2306 & 0.2029 & 0.2306 & 0.2029 \\
\hline DUM82M10 & -0.0282 & 0.7332 & -0.0665 & 0.4866 & -0.0665 & 0.4866 & -0.0692 & 0.4786 & -0.0692 & 0.4786 \\
\hline DUM85M5 & -0.1255 & 0.0181 & -0.1349 & 0.0132 & -0.1349 & 0.0132 & -0.2540 & 0.0000 & -0.2540 & 0.0000 \\
\hline DUM05M2 & -0.0788 & 0.0192 & -0.0901 & 0.0135 & -0.0901 & 0.0135 & 0.1042 & 0.0519 & 0.1042 & 0.0519 \\
\hline RECES & $0.02 \hat{3} 1$ & $0.597 \mathrm{~S}$ & 0.0197 & 0.6551 & 0.0197 & 0.6551 & 0.0051 & $0.907 \mathrm{~S}$ & 0.0051 & 0.9078 \\
\hline Constant & & & & & -0.0027 & 0.9770 & 1.0373 & 0.0000 & 1.0373 & 0.0000 \\
\hline Trend & & & & & & & -0.0023 & 0.0000 & -0.0023 & 0.0000 \\
\hline ECT & -0.1121 & 0.0000 & -0.1168 & 0.0000 & -0.1168 & 0.0000 & .0 .2346 & 0.0000 & -0.2346 & 0.0000 \\
\hline Obs & 471 & 471 & 471 & 471 & 471 & 471 & 471 & 471 & 471 & 471 \\
\hline Date & $\begin{array}{r}1976 \mathrm{mlO}^{\circ} \\
2015 \mathrm{~m} 12\end{array}$ & $\begin{array}{r}1976 \mathrm{~m}^{10} \\
2015 \mathrm{~m} 12\end{array}$ & $\begin{array}{r}1976 \mathrm{~m}_{10} 0 \\
2015 \mathrm{~m} 12\end{array}$ & $\begin{array}{r}1976 \mathrm{~m} 10- \\
2015 \mathrm{~m} 12\end{array}$ & $\begin{array}{r}1976 \mathrm{ml}^{10}- \\
2015 \mathrm{~m} 12\end{array}$ & $\begin{array}{r}1976 \mathrm{~m} 10- \\
2015 \mathrm{~m} 12\end{array}$ & $\begin{array}{r}1976 \mathrm{ml} 0 \\
2015 \mathrm{~m} 12\end{array}$ & $\begin{array}{r}1976 \mathrm{~m} 10 \\
2015 \mathrm{~m} 12\end{array}$ & $\begin{array}{r}1976 \mathrm{ml}^{10} \\
2015 \mathrm{~m} 12\end{array}$ & $\begin{array}{r}1976 \mathrm{~m} 10 \\
2015 \mathrm{~m} 12\end{array}$ \\
\hline
\end{tabular}


Table A4: Estimated Long-run and Short-run Coefficients Using the ARDL Approach (with GB5Y)

\begin{tabular}{|c|c|c|c|c|c|c|c|c|c|c|}
\hline \multicolumn{11}{|c|}{ Appendix Table A4 } \\
\hline \multicolumn{11}{|c|}{ Es timated Long-run and Short-run Coefficients using the ARDL Approach } \\
\hline \multicolumn{11}{|c|}{ (with GB5Y) } \\
\hline & \multicolumn{2}{|c|}{ Model 1} & \multicolumn{2}{|c|}{ Model 2} & \multicolumn{2}{|c|}{ Model 3} & \multicolumn{2}{|c|}{ Model 4} & \multicolumn{2}{|c|}{ Model 5} \\
\hline & Coefficient & Prob. & Coefficient & Prob. & Coefficient & Prob. & Coefficient & Prob. & Coefficient & Prob. \\
\hline \multicolumn{11}{|c|}{ Long-run Coefficients } \\
\hline R_ST & 0.6961 & 0.0000 & 0.6621 & 0.0000 & 0.6621 & 0.0000 & 0.5186 & 0.0000 & 0.5186 & 0.0000 \\
\hline INF & 0.3715 & 0.0001 & 0.2541 & 0.0001 & 0.2541 & 0.0001 & 0.4464 & 0.0000 & 0.4464 & 0.0000 \\
\hline $\mathbf{V}$ & -0.0715 & 0.2295 & -0.0713 & 0.0855 & -0.0713 & 0.0855 & -0.0130 & 0.7610 & -0.0130 & 0.7610 \\
\hline IP & 0.1066 & 0.0001 & 0.0453 & 0.0526 & 0.0453 & 0.0526 & 0.0489 & 0.0234 & 0.0489 & 0.0234 \\
\hline DUM80M12 & 3.3080 & 0.0572 & 2.5940 & 0.0306 & 2.5940 & 0.0306 & 2.5388 & 0.0288 & 2.5388 & 0.0288 \\
\hline DUM81M4 & -2.2465 & 0.2277 & -1.0376 & 0.4234 & -1.0376 & 0.4234 & -0.4451 & 0.7082 & -0.4451 & 0.7082 \\
\hline DUM82M10 & 1.3363 & 0.1194 & 0.8880 & 0.1428 & 0.8880 & 0.1428 & 1.6010 & 0.0078 & 1.6010 & 0.0078 \\
\hline DUM85M5 & -1.3943 & 0.0192 & -1.8064 & 0.0001 & -1.8064 & 0.0001 & -1.6050 & 0.0000 & -1.6050 & 0.0000 \\
\hline DUM05M2 & -0.8261 & 0.0231 & -1.2462 & 0.0000 & -1.2462 & 0.0000 & -0.5968 & 0.0790 & -0.5968 & 0.0790 \\
\hline RECES & 0.7725 & 0.0739 & 0.3514 & 0.2325 & 0.3514 & 0.2325 & 0.2739 & 0.3105 & 0.2739 & 0.3105 \\
\hline Constant & & & 1.1955 & 0.0001 & & & & & & \\
\hline Trend & & & & & & & -0.0040 & 0.0083 & & \\
\hline \multicolumn{11}{|c|}{ Short-run Coefficients } \\
\hline$\Delta($ GB5Y(-1)) & 0.3205 & 0.0000 & 0.3377 & 0.0000 & 0.3377 & 0.0000 & 0.3513 & 0.0000 & 0.3513 & 0.0000 \\
\hline$\Delta($ GB5Y(-2)) & -0.2115 & 0.0000 & -0.1917 & 0.0000 & -0.1917 & 0.0000 & -0.1863 & 0.0000 & -0.1863 & 0.0000 \\
\hline$\Delta($ GB5 Y(-3)) & 0.1232 & 0.0038 & 0.1365 & 0.0006 & 0.1365 & 0.0006 & 0.1446 & 0.0003 & 0.1446 & 0.0003 \\
\hline$\Delta($ GB5Y(-4)) & -0.0378 & 0.3562 & & & & & & & & \\
\hline$\Delta($ GB5 Y(-5)) & -0.0624 & 0.1120 & & & & & & & & \\
\hline$\Delta$ (TB3M) & 0.4865 & 0.0000 & 0.4849 & 0.0000 & 0.4849 & 0.0000 & 0.4908 & 0.0000 & 0.4908 & 0.0000 \\
\hline$\Delta($ TB3M(-1)) & -0.2440 & 0.0000 & -0.2482 & 0.0000 & -0.2482 & 0.0000 & -0.2596 & 0.0000 & -0.2596 & 0.0000 \\
\hline$\Delta$ (TB3M(-2)) & 0.2490 & 0.0000 & 0.2504 & 0.0000 & 0.2504 & 0.0000 & 0.2710 & 0.0000 & 0.2710 & 0.0000 \\
\hline$\Delta$ (TB3M(-3)) & -0.2032 & 0.0000 & -0.1857 & 0.0000 & -0.1857 & 0.0000 & -0.1997 & 0.0000 & -0.1997 & 0.0000 \\
\hline$\Delta($ TB3M(-4)) & -0.0094 & 0.8470 & -0.0058 & 0.8835 & -0.0058 & 0.8835 & 0.0125 & 0.7625 & 0.0125 & 0.7625 \\
\hline$\Delta$ (TB3M(-5)) & 0.1347 & 0.0030 & 0.1044 & 0.0102 & 0.1044 & 0.0102 & 0.0794 & 0.0557 & 0.0794 & 0.0557 \\
\hline$\Delta$ (TB3M(-6)) & -0.0944 & 0.0238 & -0.0884 & 0.0327 & -0.0884 & 0.0327 & -0.0800 & 0.0568 & -0.0800 & 0.0568 \\
\hline$\Delta$ (TB3M(-7)) & -0.0260 & 0.5289 & -0.0354 & 0.3868 & -0.0354 & 0.3868 & -0.0274 & 0.5112 & -0.0274 & 0.5112 \\
\hline$\Delta($ TB3M(-8)) & 0.1459 & 0.0002 & 0.1500 & 0.0001 & 0.1500 & 0.0001 & 0.1384 & 0.0005 & 0.1384 & 0.0005 \\
\hline$\Delta$ (TB3M(-9)) & -0.1020 & 0.0000 & -0.1002 & 0.0000 & -0.1002 & 0.0000 & -0.0848 & 0.0007 & -0.0848 & 0.0007 \\
\hline$\Delta$ (CPI) & 0.0315 & 0.0000 & 0.0304 & 0.0001 & 0.0304 & 0.0001 & 0.0200 & 0.6163 & 0.0200 & 0.6163 \\
\hline$\Delta($ CPI(-1)) & & & & & & & 0.0114 & 0.8406 & 0.0114 & 0.8406 \\
\hline$\Delta($ CPI(-2)) & & & & & & & 0.0790 & 0.1598 & 0.0790 & 0.1598 \\
\hline$\Delta($ CPI(-3)) & & & & & & & 0.0069 & 0.9022 & 0.0069 & 0.9022 \\
\hline$\Delta($ CPI(-4)) & & & & & & & -0.0865 & 0.1253 & -0.0865 & 0.1253 \\
\hline$\Delta(\mathrm{CPI}(-5))$ & & & & & & & 0.0211 & 0.7094 & 0.0211 & 0.7094 \\
\hline$\Delta($ CPI(-6)) & & & & & & & 0.0853 & 0.1323 & 0.0853 & 0.1323 \\
\hline$\Delta(\mathrm{CPI}(-7))$ & & & & & & & -0.0842 & 0.1335 & -0.0842 & 0.1335 \\
\hline$\Delta($ CPI(-8)) & & & & & & & 0.0744 & 0.1833 & 0.0744 & 0.1833 \\
\hline$\Delta($ CPI(-9)) & & & & & & & -0.0772 & 0.0383 & -0.0772 & 0.0383 \\
\hline$\Delta(\mathbf{V})$ & -0.0799 & 0.0324 & -0.0687 & 0.0651 & -0.0687 & 0.0651 & -0.0722 & 0.0514 & -0.0722 & 0.0514 \\
\hline$\Delta$ (IP) & 0.0195 & 0.0275 & 0.0148 & 0.0941 & 0.0148 & 0.0941 & 0.0066 & 0.0279 & 0.0066 & 0.0279 \\
\hline$\Delta($ IP(-1)) & 0.0120 & 0.1514 & 0.0122 & 0.1404 & 0.0122 & 0.1404 & & & & \\
\hline DUM80M12 & 0.2808 & 0.0408 & 0.3108 & 0.0228 & 0.3108 & 0.0228 & 0.3448 & 0.0186 & 0.3448 & 0.0186 \\
\hline DUM81M4 & -0.1907 & 0.2055 & -0.1243 & 0.4107 & -0.1243 & 0.4107 & -0.0604 & 0.7040 & -0.0604 & 0.7040 \\
\hline DUM82M10 & 0.1134 & 0.1178 & 0.1064 & 0.1394 & 0.1064 & 0.1394 & 0.2174 & 0.0095 & 0.2174 & 0.0095 \\
\hline DUM85M5 & -0.1183 & 0.0172 & -0.2164 & 0.0002 & -0.2164 & 0.0002 & -0.2180 & 0.0002 & -0.2180 & 0.0002 \\
\hline DUM05M2 & -0.0701 & 0.0381 & -0.1493 & 0.0001 & -0.1493 & 0.0001 & -0.0810 & 0.0948 & -0.0810 & 0.0948 \\
\hline RECES & 0.0655 & 0.0586 & 0.0421 & 0.2220 & 0.0421 & 0.2220 & 0.0372 & 0.3117 & 0.0372 & 0.3117 \\
\hline Constant & & & & & 0.1404 & 0.0010 & 0.2047 & 0.0000 & 0.2047 & 0.0000 \\
\hline Trend & & & & & & & -0.0005 & 0.0093 & -0.0005 & 0.0093 \\
\hline ECT & -0.0848 & 0.0000 & -0.1198 & 0.0000 & -0.1198 & 0.0000 & -0.1358 & 0.0000 & -0.1358 & 0.0000 \\
\hline Obs & 662 & 662 & 662 & 662 & 662 & 662 & 662 & 662 & 662 & 662 \\
\hline Date & $\begin{array}{r}1960 \mathrm{ml1}- \\
2015 \mathrm{ml} 2\end{array}$ & $\begin{array}{r}1960 \mathrm{ml1}- \\
2015 \mathrm{ml} 2\end{array}$ & $\begin{array}{r}1960 \mathrm{~m} 11- \\
2015 \mathrm{ml} 12\end{array}$ & $\begin{array}{r}1960 \mathrm{ml1}- \\
2015 \mathrm{ml} 2\end{array}$ & $\begin{array}{r}1960 \mathrm{ml1}- \\
2015 \mathrm{ml} 12\end{array}$ & $\begin{array}{l}1960 \mathrm{ml1}- \\
2015 \mathrm{ml} 2\end{array}$ & $\begin{array}{r}1960 \mathrm{ml1}- \\
2015 \mathrm{ml} 2\end{array}$ & $\begin{array}{r}1960 \mathrm{~m} 11- \\
2015 \mathrm{ml} 2\end{array}$ & $\begin{array}{r}1960 \mathrm{~m} 11- \\
2015 \mathrm{ml} 2\end{array}$ & $\begin{array}{r}1960 \mathrm{ml1}- \\
2015 \mathrm{ml} 12\end{array}$ \\
\hline
\end{tabular}


Table A5: Estimated Long-run and Short-run Coefficients Using the ARDL Approach (with GB7Y)

\begin{tabular}{|c|c|c|c|c|c|c|c|c|c|c|}
\hline \multicolumn{11}{|c|}{ Appendix Table A5 } \\
\hline \multicolumn{11}{|c|}{ Estimated Long-run and Short-run Coefficients using the ARDL Approach } \\
\hline \multicolumn{11}{|c|}{ (with GB7Y) } \\
\hline & \multicolumn{2}{|c|}{ Model 1} & \multicolumn{2}{|c|}{ Model 2} & \multicolumn{2}{|c|}{ Model 3} & \multicolumn{2}{|c|}{ Model 4} & \multicolumn{2}{|c|}{ Model 5} \\
\hline & Coefficient & Prob. & Coefficient & Prob. & Coefficient & Prob. & Coefficient & Prob. & Coefficient & Prob. \\
\hline \multicolumn{11}{|c|}{ Long-run Coefficients } \\
\hline R_ST & 0.6027 & 0.0000 & 0.6134 & 0.0000 & 0.6134 & 0.0000 & 0.4557 & 0.0000 & 0.4557 & 0.0000 \\
\hline INF & 0.4524 & 0.0000 & 0.2445 & 0.0036 & 0.2445 & 0.0036 & 0.3370 & 0.0001 & 0.3370 & 0.0001 \\
\hline V & -0.0969 & 0.1153 & -0.1063 & 0.0171 & -0.1063 & 0.0171 & -0.0379 & 0.4262 & -0.0379 & 0.4262 \\
\hline IP & 0.0874 & 0.0038 & 0.0429 & 0.0871 & 0.0429 & 0.0871 & 0.0352 & 0.1106 & 0.0352 & 0.1106 \\
\hline DUM80M12 & 3.4015 & 0.0504 & 2.7307 & 0.0289 & 2.7307 & 0.0289 & 3.3896 & 0.0031 & 3.3896 & 0.0031 \\
\hline DUM81M4 & -2.2661 & 0.2299 & -1.2586 & 0.3539 & -1.2586 & 0.3539 & -0.4475 & 0.7067 & -0.4475 & 0.7067 \\
\hline DUM82M10 & 1.9858 & 0.0245 & 1.0049 & 0.1303 & 1.0049 & 0.1303 & 1.0316 & 0.0770 & 1.0316 & 0.0770 \\
\hline DUM85M5 & -1.6785 & 0.0073 & -1.9363 & 0.0000 & -1.9363 & 0.0000 & -1.8806 & 0.0000 & -1.8806 & 0.0000 \\
\hline DUM05M2 & -1.0137 & 0.0064 & -1.3730 & 0.0000 & -1.3730 & 0.0000 & -0.5613 & 0.1409 & -0.5613 & 0.1409 \\
\hline RECES & 0.8042 & 0.0669 & 0.3881 & 0.2293 & 0.3881 & 0.2293 & 0.2729 & 0.3318 & 0.2729 & 0.3318 \\
\hline Constant & & & 1.7113 & 0.0002 & & & & & & \\
\hline Trend & & & & & & & -0.0098 & 0.0000 & & \\
\hline \multicolumn{11}{|c|}{ Short-run Coefficients } \\
\hline$\Delta($ GB7Y(-1)) & 0.3317 & 0.0000 & 0.3492 & 0.0000 & 0.3492 & 0.0000 & 0.3534 & 0.0000 & 0.3534 & 0.0000 \\
\hline$\Delta($ GB7Y Y(-2)) & -0.2213 & 0.0000 & -0.2075 & 0.0000 & -0.2075 & 0.0000 & -0.2009 & 0.0000 & -0.2009 & 0.0000 \\
\hline$\Delta($ GB7Y Y(-3)) & 0.1274 & 0.0034 & 0.1458 & 0.0008 & 0.1458 & 0.0008 & 0.1510 & 0.0005 & 0.1510 & 0.0005 \\
\hline$\Delta$ (TB3M) & 0.4021 & 0.0000 & 0.4042 & 0.0000 & 0.4042 & 0.0000 & 0.4042 & 0.0000 & 0.4042 & 0.0000 \\
\hline$\Delta(\mathrm{TB3M}(-1))$ & -0.2390 & 0.0000 & -0.2440 & 0.0000 & -0.2440 & 0.0000 & -0.2420 & 0.0000 & -0.2420 & 0.0000 \\
\hline$\Delta(\mathrm{TB3M}(-2))$ & 0.2552 & 0.0000 & 0.2550 & 0.0000 & 0.2550 & 0.0000 & 0.2562 & 0.0000 & 0.2562 & 0.0000 \\
\hline$\Delta($ TB3M(-3)) & -0.1887 & 0.0001 & -0.1946 & 0.0001 & -0.1946 & 0.0001 & -0.1938 & 0.0001 & -0.1938 & 0.0001 \\
\hline$\Delta(\mathrm{TB3M}(-4))$ & 0.0074 & 0.8650 & 0.0079 & 0.8554 & 0.0079 & 0.8554 & 0.0093 & 0.8295 & 0.0093 & 0.8295 \\
\hline$\Delta(\mathrm{TB3M}(-5))$ & 0.1007 & 0.0237 & 0.0981 & 0.0262 & 0.0981 & 0.0262 & 0.0992 & 0.0237 & 0.0992 & 0.0237 \\
\hline$\Delta($ TB3M(-6)) & \begin{tabular}{|c|}
-0.0848 \\
\end{tabular} & 0.0602 & $\begin{array}{l}-0.0826 \\
\end{array}$ & 0.0648 & -0.0826 & 0.0648 & -0.0796 & 0.0736 & -0.0796 & 0.0736 \\
\hline$\Delta($ TB3M(-7)) & -0.0335 & 0.4543 & \begin{tabular}{|l|}
-0.0351 \\
\end{tabular} & 0.4291 & -0.0351 & 0.4291 & -0.0371 & 0.4015 & -0.0371 & 0.4015 \\
\hline$\Delta(\mathrm{TB3M}(-8))$ & 0.1402 & 0.0009 & 0.1339 & 0.0014 & 0.1339 & 0.0014 & 0.1343 & 0.0013 & 0.1343 & 0.0013 \\
\hline$\Delta($ TB3M(-9)) & -0.0991 & 0.0002 & -0.0938 & 0.0003 & -0.0938 & 0.0003 & -0.0875 & 0.0008 & -0.0875 & 0.0008 \\
\hline$\Delta(\mathrm{CPI})$ & 0.0407 & 0.0000 & 0.0300 & 0.0023 & 0.0300 & 0.0023 & 0.0469 & 0.0001 & 0.0469 & 0.0001 \\
\hline$\Delta(\mathrm{V})$ & -0.0087 & 0.1582 & -0.0130 & 0.0384 & -0.0130 & 0.0384 & -0.0052 & 0.4414 & -0.0052 & 0.4414 \\
\hline$\Delta(\mathrm{IP})$ & 0.0143 & 0.1998 & 0.0093 & 0.4036 & 0.0093 & 0.4036 & 0.0098 & 0.3781 & 0.0098 & 0.3781 \\
\hline$\Delta(\operatorname{IP}(-1))$ & 0.0217 & 0.0413 & 0.0209 & 0.0475 & 0.0209 & 0.0475 & 0.0219 & 0.0367 & 0.0219 & 0.0367 \\
\hline DUM80M12 & 0.3065 & 0.0365 & 0.3353 & 0.0214 & 0.3353 & 0.0214 & 0.4719 & 0.0021 & 0.4719 & 0.0021 \\
\hline DUM81M4 & -0.2042 & 0.2062 & -0.1545 & 0.3371 & -0.1545 & 0.3371 & -0.0623 & 0.7030 & -0.0623 & 0.7030 \\
\hline DUM82M10 & 0.1789 & 0.0209 & 0.1234 & 0.1176 & 0.1234 & 0.1176 & 0.1436 & 0.0682 & 0.1436 & 0.0682 \\
\hline DUM85M5 & -0.1512 & 0.0065 & $\begin{array}{l}-0.2378 \\
\end{array}$ & 0.0001 & -0.2378 & 0.0001 & -0.2618 & 0.0000 & -0.2618 & 0.0000 \\
\hline DUM05M2 & -0.0913 & 0.0146 & -0.1686 & 0.0002 & -0.1686 & 0.0002 & -0.0781 & 0.1574 & -0.0781 & 0.1574 \\
\hline RECES & 0.0724 & 0.0540 & 0.0476 & 0.2114 & 0.0476 & 0.2114 & 0.0379 & 0.3180 & 0.0379 & 0.3180 \\
\hline Constant & & & & & 0.2144 & 0.0020 & 0.4621 & 0.0000 & 0.4621 & 0.0000 \\
\hline Trend & & & & & & & -0.0008 & 0.0059 & -0.0008 & 0.0059 \\
\hline ECT & -0.0901 & 0.0000 & -0.1228 & 0.0000 & -0.1228 & 0.0000 & -0.1392 & 0.0000 & -0.1392 & 0.0000 \\
\hline Obs & 554 & 554 & 554 & 554 & 554 & 554 & 554 & 554 & 554 & 554 \\
\hline Date & $\begin{array}{r}1969 \mathrm{ml} 1- \\
2015 \mathrm{ml} 2\end{array}$ & $\begin{array}{r}1969 \mathrm{mll}- \\
2015 \mathrm{ml} 2\end{array}$ & $\begin{array}{r}1969 \mathrm{mll}- \\
2015 \mathrm{ml} 2\end{array}$ & $\begin{array}{r}1969 \mathrm{ml} 1- \\
2015 \mathrm{ml} 2\end{array}$ & $\begin{array}{r}1969 \mathrm{ml} 1- \\
2015 \mathrm{ml} 2\end{array}$ & $\begin{array}{r}1969 \mathrm{ml} 1- \\
2015 \mathrm{ml} 2\end{array}$ & $\begin{array}{r}1969 \mathrm{mll}- \\
2015 \mathrm{ml} 2\end{array}$ & $\begin{array}{r}1969 \mathrm{ml} 1- \\
2015 \mathrm{ml} 2\end{array}$ & $\begin{array}{r}1969 \mathrm{ml} 1- \\
2015 \mathrm{ml} 2\end{array}$ & $\begin{array}{r}1969 \mathrm{ml} 1 \\
2015 \mathrm{ml} 2\end{array}$ \\
\hline
\end{tabular}


Table A6: Estimated Long-run and Short-run Coefficients Using the ARDL Approach (with GB30Y)

\begin{tabular}{|c|c|c|c|c|c|c|c|c|c|c|}
\hline \multicolumn{11}{|c|}{ Appendix Table A6 } \\
\hline \multicolumn{11}{|c|}{ Estimated Long-run and Short-run Coefficients using the ARDL Approach } \\
\hline \multicolumn{11}{|c|}{ (with GB30Y) } \\
\hline & \multicolumn{2}{|c|}{ Model 1} & \multicolumn{2}{|c|}{ Model 2} & \multicolumn{2}{|c|}{ Model 3} & \multicolumn{2}{|c|}{ Model 4} & \multicolumn{2}{|c|}{ Model 5} \\
\hline & Coefficient & Prob. & Coefficient & Prob. & Coefficient & Prob. & Coefficient & Prob. & Coefficient & Prob. \\
\hline \multicolumn{11}{|c|}{ Long-run Coefficients } \\
\hline R_ST & 0.2953 & 0.0008 & 0.3800 & 0.0000 & 0.3800 & 0.0000 & 0.1927 & 0.0088 & 0.1927 & 0.0088 \\
\hline INF & 0.7073 & 0.0000 & 0.4035 & 0.0069 & 0.4035 & 0.0069 & 0.3034 & 0.0023 & 0.3034 & 0.0023 \\
\hline $\mathbf{V}$ & -0.1358 & 0.0117 & -0.1687 & 0.0003 & -0.1687 & 0.0003 & -0.0816 & 0.0449 & -0.0816 & 0.0449 \\
\hline IP & 0.0787 & 0.0209 & 0.0573 & 0.0637 & 0.0573 & 0.0637 & 0.0081 & 0.7105 & 0.0081 & 0.7105 \\
\hline \begin{tabular}{|l|} 
DUM80M12 \\
\end{tabular} & 4.5160 & 0.0150 & 3.9442 & 0.0118 & 3.9442 & 0.0118 & 4.2366 & 0.0001 & 4.2366 & 0.0001 \\
\hline DUM81M4 & -2.4558 & 0.1845 & -2.0094 & 0.2022 & -2.0094 & 0.2022 & -1.2823 & 0.1999 & -1.2823 & 0.1999 \\
\hline DUM82M10 & 2.3266 & 0.0056 & 1.1456 & 0.1791 & 1.1456 & 0.1791 & 1.0235 & 0.0669 & 1.0235 & 0.0669 \\
\hline DUM85M5 & -1.8505 & 0.0006 & -2.0004 & 0.0000 & -2.0004 & 0.0000 & -1.8849 & 0.0000 & -1.8849 & 0.0000 \\
\hline DUM05M2 & -1.2438 & 0.0001 & -1.4978 & 0.0000 & -1.4978 & 0.0000 & -0.3976 & 0.2230 & -0.3976 & 0.2230 \\
\hline RECES & 0.6764 & 0.1452 & 0.5839 & 0.1445 & 0.5839 & 0.1445 & 0.2772 & 0.2888 & 0.2772 & 0.2888 \\
\hline Constant & & & 2.0499 & 0.0195 & & & & & & \\
\hline Trend & & & & & & & -0.0098 & 0.0000 & & \\
\hline \multicolumn{11}{|c|}{ Short-run Coefficients } \\
\hline$\Delta($ GB30Y(-1)) & 0.3312 & 0.0000 & 0.3430 & 0.0000 & 0.3430 & 0.0000 & 0.3810 & 0.0000 & 0.3810 & 0.0000 \\
\hline$\Delta($ GB30Y(-2)) & -0.1936 & 0.0001 & -0.1858 & 0.0001 & -0.1858 & 0.0001 & -0.1499 & 0.0036 & -0.1499 & 0.0036 \\
\hline$\Delta($ GB30Y(-3)) & 0.1459 & 0.0021 & 0.1634 & 0.0007 & 0.1634 & 0.0007 & 0.2006 & 0.0001 & 0.2006 & 0.0001 \\
\hline$\Delta($ GB30Y(-4)) & & & & & & & 0.0172 & 0.7324 & 0.0172 & 0.7324 \\
\hline$\Delta($ GB30Y(-5)) & & & & & & & 0.0232 & 0.6392 & 0.0232 & 0.6392 \\
\hline$\Delta($ GB30Y(-6)) & & & & & & & 0.1135 & 0.0222 & 0.1135 & 0.0222 \\
\hline$\Delta($ GB30Y(-7)) & & & & & & & 0.0463 & 0.3030 & 0.0463 & 0.3030 \\
\hline$\Delta($ GB30Y(-8)) & & & & & & & 0.1322 & 0.0031 & 0.1322 & 0.0031 \\
\hline$\Delta($ GB30Y(-9)) & & & & & & & -0.0189 & 0.6742 & -0.0189 & 0.6742 \\
\hline$\Delta($ GB30Y(-10)) & & & & & & & 0.0489 & 0.2652 & 0.0489 & 0.2652 \\
\hline$\Delta($ GB30Y(-11)) & & & & & & & 0.0928 & 0.0287 & 0.0928 & 0.0287 \\
\hline$\Delta$ (TB3M) & 0.3383 & 0.0000 & 0.3421 & 0.0000 & 0.3421 & 0.0000 & 0.3279 & 0.0000 & 0.3279 & 0.0000 \\
\hline$\Delta$ (TB3M(-1)) & -0.2631 & 0.0000 & -0.2663 & 0.0000 & -0.2663 & 0.0000 & -0.2547 & 0.0000 & -0.2547 & 0.0000 \\
\hline$\Delta($ TB3M(-2)) & 0.2948 & 0.0000 & 0.3022 & 0.0000 & 0.3022 & 0.0000 & 0.2733 & 0.0000 & 0.2733 & 0.0000 \\
\hline$\Delta($ TB3M(-3)) & -0.2353 & 0.0001 & -0.2532 & 0.0000 & -0.2532 & 0.0000 & -0.2276 & 0.0001 & -0.2276 & 0.0001 \\
\hline$\Delta($ TB3M(-4)) & 0.0986 & 0.0684 & 0.1125 & 0.0412 & 0.1125 & 0.0412 & 0.1099 & 0.0588 & 0.1099 & 0.0588 \\
\hline \begin{tabular}{|l|}
$\Delta($ TB3M(-5)) \\
\end{tabular} & -0.0036 & 0.9443 & -0.0223 & 0.6810 & -0.0223 & 0.6810 & 0.0405 & 0.4525 & 0.0405 & 0.4525 \\
\hline$\Delta($ TB3M(-6)) & -0.0350 & 0.4939 & -0.0220 & 0.6733 & -0.0220 & 0.6733 & -0.0815 & 0.0136 & -0.0815 & 0.0136 \\
\hline \begin{tabular}{|l|}
$\Delta($ TB3M(-7)) \\
\end{tabular} & -0.0408 & 0.4151 & -0.0502 & 0.3181 & -0.0502 & 0.3181 & & & & \\
\hline$\Delta($ TB3M(-8)) & 0.1149 & 0.0139 & 0.1191 & 0.0114 & 0.1191 & 0.0114 & & & & \\
\hline \begin{tabular}{|l}
$\Delta($ TB3M(-9)) \\
\end{tabular} & -0.0730 & 0.0130 & -0.0762 & 0.0095 & -0.0762 & 0.0095 & & & & \\
\hline$\Delta(\mathrm{CPI})$ & 0.0827 & 0.1509 & 0.0625 & 0.2802 & 0.0625 & 0.2802 & 0.0607 & 0.2865 & 0.0607 & 0.2865 \\
\hline$\Delta(\mathrm{CPI}(-1))$ & -0.0289 & 0.7222 & -0.0279 & 0.7306 & -0.0279 & 0.7306 & -0.0838 & 0.2997 & -0.0838 & 0.2997 \\
\hline$\Delta(\mathrm{CPI}(-2))$ & 0.1266 & 0.1158 & 0.1095 & 0.1754 & 0.1095 & 0.1754 & 0.1170 & 0.1498 & 0.1170 & 0.1498 \\
\hline$\Delta(\mathrm{CPI}(-3))$ & 0.0303 & 0.7088 & 0.0458 & 0.5729 & 0.0458 & 0.5729 & 0.0128 & 0.8757 & 0.0128 & 0.8757 \\
\hline$\Delta(\mathrm{CPI}(-4))$ & -0.0374 & 0.6464 & -0.0373 & 0.6453 & -0.0373 & 0.6453 & -0.0387 & 0.6376 & -0.0387 & 0.6376 \\
\hline$\Delta(\mathrm{CPI}(-5))$ & -0.0646 & 0.4264 & -0.0804 & 0.3224 & -0.0804 & 0.3224 & -0.0597 & 0.4541 & -0.0597 & 0.4541 \\
\hline$\Delta($ CPI(-6)) & 0.1949 & 0.0170 & 0.1986 & 0.0145 & 0.1986 & 0.0145 & 0.2445 & 0.0022 & 0.2445 & 0.0022 \\
\hline$\Delta(\mathrm{CPI}(-7))$ & -0.0827 & 0.3114 & -0.0635 & 0.4392 & -0.0635 & 0.4392 & -0.1001 & 0.2103 & -0.1001 & 0.2103 \\
\hline$\Delta(\mathrm{CPI}(-8))$ & 0.0190 & 0.8134 & 0.0185 & 0.8169 & 0.0185 & 0.8169 & 0.0184 & 0.8160 & 0.0184 & 0.8160 \\
\hline$\Delta(\mathrm{CPI}(-9))$ & -0.0876 & 0.0944 & -0.1638 & 0.0420 & -0.1638 & 0.0420 & -0.0914 & 0.0812 & -0.0914 & 0.0812 \\
\hline$\Delta($ CPI(-10)) & & & 0.0749 & 0.1618 & 0.0749 & 0.1618 & & & & \\
\hline$\Delta(\mathbf{V})$ & -0.0136 & 0.0348 & -0.0197 & 0.0051 & -0.0197 & 0.0051 & -0.0144 & 0.0645 & -0.0144 & 0.0645 \\
\hline$\Delta$ (IP) & 0.0116 & 0.3594 & 0.0107 & 0.3967 & 0.0107 & 0.3967 & 0.0060 & 0.6386 & 0.0060 & 0.6386 \\
\hline$\Delta(\mathbf{I P}(-1))$ & 0.0439 & 0.0165 & 0.0425 & 0.0199 & 0.0425 & 0.0199 & 0.0443 & 0.0149 & 0.0443 & 0.0149 \\
\hline$\Delta(\mathbf{I P}(-2))$ & -0.0270 & 0.0270 & -0.0236 & 0.0543 & -0.0236 & 0.0543 & -0.0267 & 0.0292 & -0.0267 & 0.0292 \\
\hline DUM80M12 & 0.4523 & 0.0058 & 0.4610 & 0.0061 & 0.4610 & 0.0061 & 0.7483 & 0.0000 & 0.7483 & 0.0000 \\
\hline \begin{tabular}{|l|} 
DUM81M4 \\
\end{tabular} & -0.2459 & 0.1437 & -0.2348 & 0.1730 & -0.2348 & 0.1730 & -0.2264 & 0.1747 & -0.2264 & 0.1747 \\
\hline \begin{tabular}{|l|} 
DUM82M10 \\
\end{tabular} & 0.2330 & 0.0086 & 0.1339 & 0.1754 & 0.1339 & 0.1754 & 0.1807 & 0.0674 & 0.1807 & 0.0674 \\
\hline DUM85M5 & -0.1853 & 0.0016 & -0.2338 & 0.0002 & -0.2338 & 0.0002 & -0.3329 & 0.0000 & -0.3329 & 0.0000 \\
\hline DUM05M2 & -0.1246 & 0.0020 & -0.1750 & 0.0002 & -0.1750 & 0.0002 & -0.0702 & 0.2353 & -0.0702 & 0.2353 \\
\hline RECES & 0.0677 & 0.1394 & 0.0682 & 0.1365 & 0.0682 & 0.1365 & 0.0489 & 0.2827 & 0.0489 & 0.2827 \\
\hline \begin{tabular}{|l|} 
Constant \\
\end{tabular} & & & & & 0.2948 & 0.0090 & 1.3575 & 0.0000 & 1.3575 & 0.0000 \\
\hline Trend & & & & & & & & & -0.0017 & 0.0001 \\
\hline ECT & -0.1002 & 0.0000 & -0.1169 & 0.0000 & -0.1169 & 0.0000 & -0.1766 & 0.0000 & -0.1766 & 0.0000 \\
\hline Obs & 463 & 463 & 463 & 463 & 463 & 463 & 463 & 463 & 463 & 463.0000 \\
\hline Date & $\begin{array}{l}1977 \mathrm{mb}- \\
2015 \mathrm{ml} 2\end{array}$ & $\begin{array}{l}1977 \mathrm{mb}- \\
2015 \mathrm{ml} 2\end{array}$ & $\begin{array}{l}1977 \mathrm{mb}- \\
2015 \mathrm{ml} 2\end{array}$ & $\begin{array}{l}1977 \mathrm{~m} 6- \\
2015 \mathrm{~m} 12\end{array}$ & $\begin{array}{l}1977 \mathrm{mb}- \\
2015 \mathrm{ml} 2\end{array}$ & $\begin{array}{l}1977 \mathrm{mb}- \\
2015 \mathrm{ml} 2\end{array}$ & $\begin{array}{l}1977 \mathrm{mb}- \\
2015 \mathrm{ml} 2\end{array}$ & $\begin{array}{l}1977 \mathrm{mb}- \\
2015 \mathrm{ml} 2\end{array}$ & $\begin{array}{l}1977 \mathrm{mb}- \\
2015 \mathrm{ml} 2\end{array}$ & $\begin{array}{l}1977 \mathrm{~m} 6- \\
2015 \mathrm{~m} 12\end{array}$ \\
\hline
\end{tabular}

